\title{
MYTH, SYMBOL, AND Colonial ENCOUNTER
}

BRITISH AND MI'KMAQ IN ACADIA, 1700-1867

JENNIFER REID

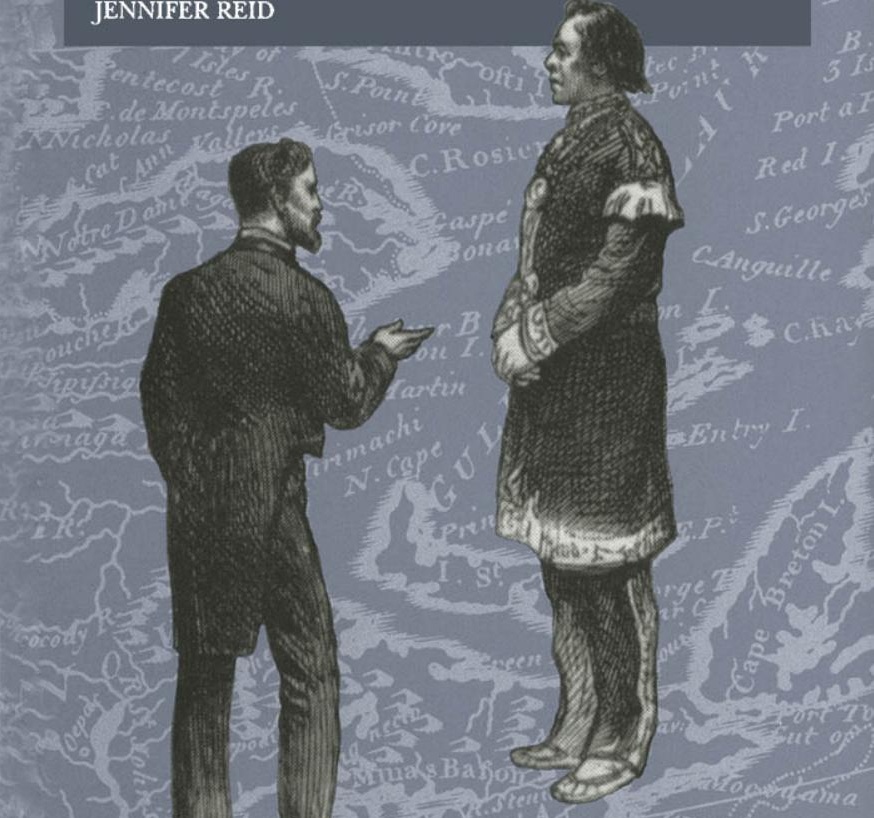

at. .

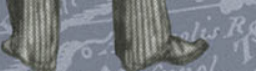

\section{RELIGIONS AND BELIEFS}


Myth, Symbol, and Colonial Encounter 


\section{RELIGIONS AND BELIEFS SERIES}

The series includes books bearing on the religions of the Americas, the Bible in its relationship to cultures, and on ethics in relation to religion. The series welcomes manuscripts written in either English or French.

\section{Editorial Committee}

Robert Choquette, Director

Margaret Dufour-McDonald

David Jeffrey

Pierre Savard

In the same series

Pauline Côté, Les transactions politiques des croyants, 1993

Adolf Ens, Subjects or Citizens?: The Mennonite Experience in

Canada, 1870-1925, 1994

Robert Choquette, The Oblate Assault on Canada's Northwest, 1995 


\section{RELIGIONS AND BELIEFS SERIES, NO. 4}

\section{Myth, Symbol, and Colonial Encounter}

British and Mi'kmaq in Acadia, 1700-1867

JENNIFER REID 
This book has been published with the help of a grant from the Canadian Federation for the Humanities, using funds provided by the Social Sciences and Humanities Research Council of Canada.

University of Ottawa Press gratefully acknowledges the support extended to its publishing program by the Canada Council, the Department of Canadian Heritage, and the University of Ottawa.

\section{CANADIAN CATALOGUING IN PUBLICATION DATA}

Reid, Jennifer, 1962-

Myth, Symbol, and Colonial Encounter: British and Mi'kmaq in Acadia, 1700-1867

(Religions and Beliefs series; no. 4)

Includes bibliographical references and index.

ISBN 0-7766-0416-3

1. Micmac Indians-Maritime Provinces-History-18th century. 2. Micmac Indians-Maritime Provinces-History-19th century. 3. Indians of North AmericaCanada-Government relations-To 1830. 4. Indians of North America-CanadaGovernment relations-1830-1860. 5. Micmac Indians-Religion. 6. Indians of North America-Maritime Provinces-Religion. 7. Acadia-History. I. Title. II. Series.

Cover design: Robert Dolbec

Cover illustrations: Details from National Archives of Canada, NMC 6969 and Olive Patricia Dickason, Canada's First Nations: A History of Founding Peoples from Earliest Times (Toronto: McClelland \& Stewart, 1992), page 287.

Typesetting: Infographie G.L.

"All rights reserved. No part of this publication may be reproduced or transmitted in any form or any means, electronic or mechanical, including photocopy, recording, or any information storage and retrieval system, without permission in writing from the publisher." 
For my parents, Bill and Irene, and my girls, Kate and Margaret 
This page intentionally left blank 


\section{ACKNOWLEDGMENTS}

In completing this book, I have been fortunate to receive various forms of assistance from many people. I must thank especially Robert Choquette, my graduate advisor at the University of Ottawa for his ongoing guidance and patience. For the conversations, critical comments, and support they have provided, I wish also to express my gratitude to Murdena Marshall, Alice Keefe, Marie-Françoise Guédon, William Green, and Charles MacDonald. And for teaching me how to ask new questions, I am grateful to Charles Long. 
This page intentionally left blank 


\section{CONTENTS}

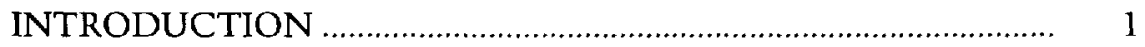

CHAPTER 1 - RELIGION AND THE COLONIAL WORLD ....... 9

CHAPTER 2 - LET NOT THY LEFT HAND KNOW WHAT THY RIGHT HAND DOETH................................. 27

CHAPTER 3 - THE SHROUDING OF AMBIGUITY ................... 53

CHAPTER 4 - THE BOUNDARIES OF PURITY …....................... 73

CHAPTER 5 - AT HOME IN COLONIAL ACADIA ……….......... 97

CONCLUSION - STILL STRANGERS ...................................... 109

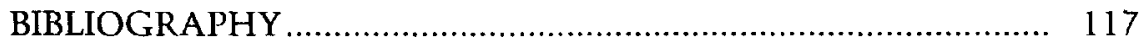

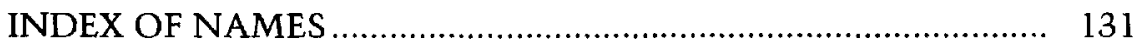


This page intentionally left blank 


\section{INTRODUCTION}

$\mathrm{T}$ HIS book is unabashedly concerned with the well-trod issue of nativewhite relations in Canada. I admit that the theme may be at best fashionable, at worst overworked; yet it remains that a great deal has yet to be said on the subject. My hope is that there might be some constructive value in approaching the issue from what will no doubt appear to be a less conventional perspective. The perspective I am suggesting is that of religion, and its value lies, I hope, in its potential for creatively confronting a problem of community that plagues Canadian society. I would call this a problem of "alienation" and suggest that it is anchored in the character of the historical relationship between European Canadians and all others. For non-Europeans the problem has to do with alienation from dominant structures of human significance in society. For Europeans it has to do with alienation from the capacity for recognizing the human composition of Canadian society and, consequently, of our own human significance. The dynamics of this problem have evolved within the arena of colonial relationships, and so it is to these relationships that we must look if we are to understand not only the roots of these forms of alienation but a mode of escaping from their constraint.

Scholars in Canada, from at least as early as the mid-eighteenth century, have continually confronted the question of where to place this country's first peoples in relation to their general formulations of

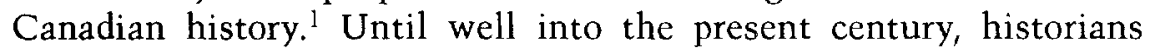
tended to fashion depictions of native peoples in their works on the basis of utility to their own community, and at various times this has consequently meant that Canadian histories have amounted to chronicles of white achievements in which non-Europeans have not been 
depicted at all. Bruce Trigger has suggested that earliest consciously historical work in this country was to substantial degree patterned on Charlevoix's Histoire et description générale de la Nouvelle France, published in 1744. Charlevoix's concern was with French colonial activity in America, with imperial contestation over land, and with missionization of the continent's native population. His view of aboriginal peoples was clearly positive, although Trigger points out that this had a great deal to do with his own Jesuit formation as an Enlightenment scholar, committed to the principles of universal reason. ${ }^{2}$ Early nineteenth-century histories by writers such as George Heriot and William Smith were influenced substantially by Charlevoix. Writing during a period in which the threat of American invasion loomed large and Indian support for the British was being courted and relied upon, these historians chose to replicate Charlevoix's genial images of native peoples in their respective works. ${ }^{3}$

In the wake of the War of 1812 , interest in the native community waned considerably. By mid-century, evolutionary notions of human development that were intrinsically racist had begun to filter into the British North American colonies from the United States, and these were propagated in colonial historical writing. ${ }^{4}$ François-Xavier Garneau's Histoire du Canada, published beginning in 1845, set the groundwork for later Quebec historians' degrading descriptions of native peoples ${ }^{5}$ that culminated in assertions of "biological superiority of the French over the Indians and Métis" by the early part of the twentieth century. ${ }^{6}$ In English, work such as John McMullen's History of Canada (1855) mirrored this trend to regard native peoples as less human than animal. ${ }^{?}$ To be sure, not all scholarship of the period was so self-consciously racist. Writers such as John William Dawson asserted that European dominance was a product of advanced culture rather than of biology, yet he, and other scholars like him, shared the certainty that native culture would ultimately disappear as native peoples were assimilated into white society. ${ }^{8}$

In the twentieth century, and until relatively recently, aboriginal peoples have been largely disregarded in general histories. However, with the publication of Harold Innis's The Fur Trade in Canada in 1930, a handful of scholars began to reintroduce Canada's first peoples into their historical work. ${ }^{9}$ Although Innis chose to account for all behaviour connected with the fur trade in terms of economic factors (with no consideration of possible native cultural factors), the fact that aboriginal peoples were presented as independent and meaningful entities beyond the point of earliest contact signified a shift in perspective and initiated further research in the same general area. Influenced by both Innis and Thomas McIlwraith (an anthropologist at the University 
of Torontol, Alfred Bailey published The Conflict of European and Eastern Algonkian Cultures, 1504-1700: A Study in Canadian Civilization, in 1937. In the book, Bailey adopted a culturally relative approach to the issue of native responses to early colonialism in eastern Canada. Following Bailey's publication, a growing body of scholars began to focus more specifically upon not only the role and responses of native peoples in the fur trade but on their culturally specific understandings of the history of which they were a part. Included here are Arthur Ray's and Donald Freeman's analysis of trade centring around Hudson's Bay, Robin Fisher's work concerning nineteenth-century British Columbia, Daniel Francis and Toby Morantz's study of seventeenth- and eighteenth-century James Bay, and Sylvia Van Kirk's work on women in western Canadian fur trade society. ${ }^{10}$

With the advent of the ethnohistorical approach to historical studies in the last two decades in Canada, scholars have begun to consider more directly the relationship between native and non-native peoples throughout the colonial period. Ethnohistory-what James Axtell has described as "a common-law marriage of history and anthropology"11_-gained the attention of the academic community with Francis Jennings's The Invasion of America, a brilliant study of seventeenth-century New England, published in $1975 .{ }^{12}$ With its focus on the reciprocal nature of colonial contact, ethnohistorical method has yielded some of the most provocative re-readings of Canadian history yet to appear. Notable among these are John Tobias's discussion of the late nineteenth-century Plains Cree, Bruce Trigger's Natives and Newcomers and The Children of Aataentsic, J. R. Miller's Skyscrapers Hide the Heavens, and James Axtell's The Invasion Within. ${ }^{13}$ However, despite the fact that it provides very new and welcome readings of a collective past that has been manipulated in the interests of white Canadians, ethnohistory may be limited in its potential for reaching the hearts of those of us who most need to relearn our past.

It is for this reason that this book presumes to confront, yet again, the issue of native-white relations in Canada. What I perceive to be the particular limitations of ethnohistory will be examined in more detail in the following chapter. What I am suggesting here is that by considering the problem from the perspective of religion, something may be said that is not only new, but of some constructive value.

More specifically, the method employed in this book may be broadly situated in the field of history of religions. Known in the nineteenth century as the "science of religions" /a nomenclature first applied by Max Muller in the preface of his 1867 work Chips From $a$ German Workshopl, ${ }^{14}$ the discipline has had a variegated recent history 
in terms of both theory and interpretation of what we choose to call "religion." 15 Indeed it is this diversity that might constitute the most engaging and potentially profitable characteristic of the history of religions. As Lawrence Sullivan notes:

There is no need to be shy about claiming descent from James Frazer, Carl Clemen, Raffaele Pettazzoni, Gerardus van der Leeuw, or Mircea Eliade, because no compulsion drives one to apply their schemes to [any given] materials. Their theoretical foundations and specific interpretations are dated in many cases and are problematic or unacceptable in others, yet the diversity of their approaches puts us at ease. This diversity illustrates a remarkable freedom of theoretical approach in a field where dissimilar methods and discordant hypotheses have sparked keen, original insights. ${ }^{16}$

The mode by which religion will be considered in this book may come as a surprise to many readers, yet it may be said to be an exploration of that "freedom of theoretical approach" to which Sullivan has referred. We should pay close attention from the outset to Jonathan $Z$. Smith's critical statement that "there is no data for religion. Religion is solely the creation of the scholar's study. It is created for the scholar's analytical purposes by his imaginative acts of comparison and generalization. ${ }^{\prime 17}$ The subtext here might read that the scholar's notion of what constitutes religion is very much dependent upon the reason the scholar has for writing. As will become more evident in the course of this analysis, this writer would like white Canadians to come to a more authentic understanding of their situation in the time and space we have called the New World. That being the case, I have chosen to locate the discussion of religion firmly in that context.

In his Patterns in Comparative Religion, Mircea Eliade afforded a religious valuation to materiality that in many respects sets the stage for an analysis such as this. Among historians of religion, Eliade was the first to relate human consciousness to a world of "matter" beyond itself. He located the hierophany - that through which the sacred is manifest to human beings-in rocks, in the sky, in the sun, indeed "in anything man has ever handled, felt, come in contact with or loved."18 The critical point for Eliade was that human religious being emerges in relation with the materiality of existence. Eliade's "religious imagination of matter, ${ }^{19}$ though located in the realm of primordiality, reminds us of the inseparable relationship between religious and historical being. With this association in mind, and guided by the imperative of American historian of religion Charles Long to situate the study of religion within the "history of contact with the finite other," ${ }^{20}$ this work will seek to locate colonial religious being (both native and white) not only within the context of the colonial world but in relation to one of its central forms of materiality: the land. 
To confront the problem of alienation from a religious and historical perspective thus grounded in human relationships with the land of a very particular context might prove to be an exercise with potentially more far-reaching utility.

This problem of alienation spans the breadth of Canadian history, but its roots run much more deeply than this-we might say to the inception of the New World itself. The "discovery" of America gave rise to a historical context in which all New World peoples have been continually disengaged either, in the case of peoples of colour, from white arenas of valuation or, in the case of whites, from authentic perceptions of reality. The notion of "discovery" itself has rested on an assumption that the New World contained nothing of human significance before the incursion of Europeans when it became part of human history. In discovering America, Europeans really discovered their own power to imagine other worlds, for they imputed meanings upon regions of the globe that were often distinct from historical reality, and they simultaneously discovered the power to re-create the world according to their meanings. For whites, the Americas were there to be remade, not to be experienced, and colonial Europeans have strenuously resisted the possibility of allowing the originality of the New World to impact upon them.

We have shrouded non-Europeans in the finery of our daydreams, rendering them all but invisible to us, ${ }^{21}$ and we have spoken of ourselves as though our entry into the New World and our subsequent attempts to transform that world have had but little impact upon our identity. So, for example, we remain "hyphenated" New World peoples-French-Canadians, English-Canadians, Irish-Canadians, and so on. The "discovery" of the New World has been an act of self-deception with devastating consequences for those human beings who have been forced to struggle for both physical and cultural survival. In a less obvious sense, it has also wrought havoc upon the meaning of the descendants of Europeans who have been compelled into violent modes of thinking and being in order to sustain a sense of identity that is uninfluenced by the human character of the New World. ${ }^{22}$

More specifically, this problem of alienation in its variety of forms has been incessant in Canada's Maritime Provinces for at least as long as the British have been there, ${ }^{23}$ and although I do not believe that it is insoluble, its resolution requires something just short of a cultural transformation. This work is intended to signal a doorway through which the possibility of such transformation exists. This will be a discussion woven between the eighteenth- and nineteenth-century British and $\mathrm{Mi}^{\prime} \mathrm{kmaq}$ communities in Nova Scotia, New Brunswick, and Prince Edward Island; but it will also be self-consciously an analysis that is 
focussed upon the descendants of Europeans. This may appear to run counter to recent ethnohistorical trends, but it is not intended to do so. It is, rather, a project that will seek to extend the ethnohistorical approach, and will consequently take as the locus of discussion the relationship between native and white communities, to which ethnohistorians have correctly turned our attention. The options for transformation that will emerge, however, are unquestionably directed towards whites. Although the $\mathrm{Mi}^{\prime} \mathrm{kmaq}$ community is besieged by many problems and most (if not all) of these are products of colonial contact, it is a community that has survived in Eastern Canada for thousands of years, and it will survive these problems too. The Mi'kmaq need no well-meaning affirmations and guidance from the white community, nor from the work of white scholars. What we can offer is the possibility of solving their difficulties unencumbered by systemic alienation; and that, I believe, is something. As a scholar I choose to pay careful attention to Claude Lévi-Strauss's warning that "our own society is the only one which we can transform yet not destroy, since the changes that we should introduce would come from within." 24

\section{Notes}

1. References in the following overview of the development of historical studies concerning native peoples in Canada are taken sporadically from Trigger's excellent article, "The Historians' Indian: Native Americans in Canadian Historical Writing from Charlevoix to the Present," 315-342.

2. Charlevoix, Histoire et description générale de la Nouvelle France. Cf. Trigger, "The Historians' Indian," 316-317.

3. Heriot, The History of Canada from Its First Discovery, Smith, History of Canada, From Its First Discovery, to the Peace of 1763. Cf. Trigger, "The Historians' Indian," 318.

4. It was perhaps the work of the American Francis Parkman that most substantially impacted upon late nineteenth-century racist historical writing on aboriginal peoples in Canada. Trigger notes that especially influential in this respect was his book The lesuits in North America in the Seventeenth Century. See Trigger, "The Historians' Indian," 320-321.

5. Garneau, Histoire du Canada depuis sa découverte jusqu'à nos jours. Cf. Trigger, "The Historians' Indian," 319.

6. See, for instance, Lionel-Adolphe Groulx, La naissance d'une race. Cf. Trigger, "The Historians' Indian," 320.

7. McMullen, The History of Canada From its First Discovery to the Present Time. Cf. Trigger, "The Historians' Indian," 320.

8. Dawson, Fossil Men and Their Modern Representatives. In this vein, Trigger, 321, also refers to Wilson, Prehistoric Man, and Hale, The Iroquois Book of Rites.

9. Innis, The Fur Trade in Canada. Cf. Trigger, "The Historians' Indian," 324. 
10. Ray and Freeman, Give Us Good Measure; Ray, Indians in the Fur Trade; Fisher, Contact and Conflict; Francis and Morantz, Partners in Furs. Cf. Trigger, "The Historians' Indian," 326-328, and Van Kirk, Many Tender Ties.

11. Axtell, The European and the Indian, vii.

12. Jennings, The Invasion of America. Jennings's concern has been predominantly with the relationships between American peoples rather than with the problem of "culture change" within specific groups. See also Jennings, Empire of Fortune, xxii.

13. Tobias, "Canada's Subjugation of the Plains Cree, 1879-1885," 519-548. Cf. Trigger, "The Historians' Indian,"337; Trigger, Natives and Newcomers; Trigger, The Children of Aataentsic; Miller, Skyscrapers Hide the Heavens; Axtell, The Invasion Within.

14. Muller, Chips From a German Workshop, cited in Eliade, The Scared and the Profane, 216.

15. For an excellent catalogue of sources dealing with the development of the discipline of history of religions, see Sullivan, Icanchu's Drum, 695, n. 54.

16. Sullivan, Icanchu's Drum, 15.

17. Smith, Imagining Religion, xi.

18. Eliade, Patterns in Comparative Religion, foreword and 11.

19. The terminology is used frequently by Charles H. Long. I first came across its use in the introduction to "Colonial Discourse in the Study of Religion," a course taught by Dr. Long at Syracuse University in 1988.

20. Ibid.

21. In discussing this experience of having one's meaning rendered obscure, Long referred to Ralph Ellison's Invisible Man, in which he described himself as "an invisible man [who] has been surrounded by mirrors of hard distorting glass. When they approach me they see only my surroundings, themselves, or figments of their imaginationsindeed, everything and anything except me." Long, Significations, 50.

22. I use the term violence in this context to refer to a mode of valuation rather than to a narrow conception of physical abuse, although this certainly falls under its rubric. Violence is the desire to dominate, to deny others their freedom of action or selfexpression, and to deny the mutuality of human relationships. For this interpretation I am drawing on the work of Paul Ricoeur, who suggested: "what unifies the problem of violence is not the fact that its multiple expressions derive from one or another form that is held to be fundamental, but rather that it is language that is its opposite. It is for a being who speaks, who in speaking pursues meaning, who has already entered the discussion and who knows something about rationality that violence is or becomes a problem" (Political and Social Essays, 89).

23. In this essay, the term British will be used to refer to colonials whose ancestry can be traced to anywhere in the British Isles.

24. Lévi-Strauss, Tristes Tropiques, 392. 
This page intentionally left blank 


\section{CHAPTER ONE \\ RELIGION AND THE COLONIAL WORLD}

The native of the land is still a stranger

The native of the land is in no man's land. . .

-Rita Joe ${ }^{1}$

$\mathrm{T}$

HE Oxford Dictionary defines the word stranger as a "foreigner, a person in a country or town or company that he does not belong to." Rita Joe is Mi'kmaq, a poet born of a community of people who have lived in the region of Acadia ${ }^{2}$ for at least five thousand years. She is also a stranger. She has experienced the ambiguity of the post-Columbian world, as one who knows her home has been re-created by a "company" of people to which she does not belong, a company that has taken precautions against her inclusion in a society constructed on the graves of her great-grandparents. ${ }^{3} \mathrm{Her}$ sense of estrangement points not only to a failure of human community, but more specifically to the failure of European Canadians to acknowledge the meaningful presence of a substantial number of human beings with whom they have shared their corner of the Americas.

This sort of denial of mutuality comes perilously close to a denial of demographic reality, and consequently raises at least two critical issues: the first concerns the question of why it is that white colonials have historically confronted their world in a piecemeal fashion, thus 
alienating themselves from selected "others"; and the second concerns the problem of whether or not we can do otherwise-whether we have other options for confronting our world in a more authentic manner, thereby allowing us to distance ourselves from a distasteful historical tradition of alienating and devaluing our fellow human beings.

Since the introduction of the ethnohistorical approach to nativewhite relations in the mid 1970s, many historians have sought to rethink colonial history in terms of human relationships, thereby demonstrating that post-colonial societies are the "mutual products" of all New World peoples. ${ }^{4}$ They have thus hoped to demonstrate that the notion of culturally pure societies that has sustained white alienation of non-whites is without substance. Scholars like J. R. Miller have applied the ethnohistorical approach within the Canadian context and have had a good deal of success in dealing with the first issue raised above-why it is that whites have estranged native peoples from the social, economic, and political structures they value in Canadian society. In his book Skyscrapers Hide the Heavens, Miller has suggested that

the relationship between the indigenous peoples and non-natives has been shaped by practical, often economic, factors. The record of Indian-white relations in Canada is one molded by the reasons that the various parties have had for making contact and maintaining relations. ${ }^{5}$

Alienation of native peoples can be accounted for, Miller believes, by this fact of expediency. As the fur trade declined and colonization became a priority for incoming Europeans, the native community was regarded as an impediment to settlement, and the destruction that followed was a consequence of this. ${ }^{6} \mathrm{He}$ goes on to demonstrate that indigenous Canadians have consistently influenced the political, economic, and social fabric of Canadian society, a fact that he feels has not been sufficiently recognized by white Canadians. In fact his principal goal in writing the book hinges on this point: "If these pages succeed in persuading some people that the native peoples have always been active, assertive contributors to the unfolding of Canadian history, they will have achieved their primary objective. ${ }^{\prime 7}$ This constitutes the foundation on which Miller attempts to contend with the second issue raised at the beginning of the chapter, that of whether-or how-it is possible for white Canadians to enter into a truly constructive relationship with aboriginal peoples, a relationship fabricated upon mutual recognition of a shared humanity.

It is at this point that his options are significantly attenuated. Knowledge of the fact that native Canadians have contributed to the 
formation of Canadian society should be sufficient, he hopes, to induce whites to enter into genuine discourse, or "meaningful consultation" with them. ${ }^{8}$ The sentiment is heartfelt, to be sure, but the possibility for its realization is unlikely. This is not to suggest that Miller is an isolated idealist, but only that the approach to the problem of nativewhite relations that he competently represents in the Canadian context may be inadequate given the depth of the problem itself. That knowledge of historical truth should bring about a fundamental transformation within the hearts and minds of those who presumably lived formerly in ignorance, is a form of optimism that stumbles in the face of the reality of colonialism. In reference to this question of ignorance, the historian of religion Charles Long has pointed to the white Mississippi boy in Faulkner's Intruder in the Dust who asked an adult why, when a white mob discovered that the man they were about to lynch was innocent, they failed to acknowledge the mistake and apologize. The older man answered that

though they do not make public and concrete amends, they know and they remember. But it is a memory that is concealed, for to make [it] concrete and public would be to plunge the community into a radically contingent state.

White Canadians, like Faulkner's mob, are not blind victims of ignorance in respect to the reality of their having shared this place with aboriginal peoples. A genuine recognition of the human composition of Canadian society and a consequent embrace of relationships founded in mutuality are not simply a matter of knowing that others have been here in some meaningful capacity for longer than whites can possibly remember. It may be, rather, a matter of understanding why this knowledge has historically had very little significance for the white community. This kind of question contains a very different sort of dynamic than that of many historical questions. Its underlying assumption is that it is not historical fact that must constitute the focus of inquiry but notions of what is meaningful that emerge in the midst of such fact.

The places in which fact and meaning diverge / when, for instance, we discover groups of human beings who fail to acknowledge other groups of humans as autonomous agents) are more than just cannonfodder for historians' pleas that future actions be based upon past reality. They are also spaces in historical studies that invite speculation on behaviour that goes beyond history. In other words, they are moments for which social, political, or economic factors fail to fully account, for they are refractions of the creative capacity of the human imagination. Although this capacity exists within history, it does not necessarily 
exist in accord with history, if we mean by "history" some objective chain of events. It is for this reason that calls for human behaviour that bear some consistency with the chain are generally ineffectual.

Does this mean that historians are constrained by their data from contributing to the sorts of transformation suggested by our second issue above? Certainly not. In fact, one might argue that such transformation is possible only within a context of profound self-knowledge and since there is no identifiable moment that separates past from present, such knowledge must be, to a great measure, retrospective. Edward $\mathrm{T}$. Hall underscored the necessity for self-understanding when he wrote:

The analysis of one's own culture simply makes explicit the many things we take for granted in our everyday lives. Talking about them, however, changes our relation with them. We move into an active and understanding correspondence with those aspects of our existence which are all too frequently taken for granted or which sometimes weigh heavily on us. Talking about them frees us from their restraint. ${ }^{10}$

In speaking of historical studies, Roy Harvey Pearce similarly noted: "Knowing the past ... [the historian] will perhaps begin to free himself of the limitations which he sets about him and to use more intelligently the opportunities it offers him."11 Yet recounting facts alone does not engender retrospective knowledge of this sort; facts and events are meaningless unless the historian is able to situate them within some form of explanatory framework ${ }^{12}$ that reflects back on the historian or the historian's community. Facts delineated chronologically provide what Ernst Cassirer has referred to as "a skeleton of history" devoid of the very vitality of human existence that historians seek to understand:

In history we regard all the works of man, and all his deeds, as precipitates of his life; and we wish to reconstitute them into this original state, we wish to understand and feel the life from which they are derived. ${ }^{13}$

It is through this desire for understanding that historians enter into a creative process, engaging themselves with sources that are representations of inaccessible events, in such a way as to engender something very new in the moment of coming together. The historian Welf Heik addressed this point when he asked the question of whether any goodquality historical work could be written without the historian beginning in the sphere of the imagination. He suggested that there exists between historical material and the writer a space that can only be 
bridged by an act of creativity. ${ }^{14}$ Resulting "histories" are something quite distinct from the events themselves, for they are, in the first instance, the creations of the historian. ${ }^{15}$ In this sense, Lucien Febvre's assertion that "there is no history, there are only historians"16 is not distant from the reality of historical analysis.

As the past is exhausted in order to understand what is significant for human beings, the fixed quality of historical events emerges as a limitation that must be circumvented. In attempting to do this we discover the need to subject these moments to questions that are other than historical. Marshall Hodgson confronted this paradox in The Ven'ture of Islam:

Whether the objects of the questions are dated or dateless, the questions themselves (as befits a cumulative discipline) ought to be, in some degree, of timeless significance to human beings: sometimes perhaps leading to manipulative power, but always leading to better understanding of the things that matter to us humanly ... here we cannot rule out a potential need to develop relatively dateless generalizations, for instance about what may be possible in cultural change, such generalizations are not simply derivable from any other discipline as such, yet they are necessary for studying what is timelessly important about the dated and placed events of human culture. ${ }^{17}$

Although Hodgson could not locate a comprehensive disciplinary framework for generating timeless questions, his suggestion of a fusion between the dated and the dateless resonates with the religious character of the human species. Despite the fact that human beings are historical in terms of physical existence, we are religious in the sense that we lay claim to the ability to re-imagine history in such a way as to give our lives meaning. Hence our condition of being dated and placed coexists with our ability to transcend time and space in the interest of retaining a sense of our own significance in the face of historical reality. ${ }^{18}$ Historians of religion have for some time stressed the fact that religion cannot be studied apart from history. ${ }^{19}$ Perhaps the reverse might also be true. To examine history from the perspective of human religiosity might well prove to be an effective manner of acquiring knowledge of what "matters to us humanly." There is no doubt that some ethnohistory has already tended to approach historical material from such a perspective. Francis Jennings, in his discussion of the American "conquest myth," for instance, has explored the relationship between the "myth" and the ways in which Americans of European descent have spoken and thought about the New World. What is being suggested here, perhaps, is an increased self-consciousness on the part of the historian in terms of the use of religious language and methodology. 20 
In respect to this particular analysis of Acadia, it is important that we begin with the necessity for transformation of white Canadian attitudes. Whites approach aboriginal peoples as strangers, despite our knowledge of a history that demonstrates they are not. In confronting the problem, it must be recognized that we are clearly dealing with modes of existence that go beyond history. If we truly want to alter white patterns of behaviour, we must come to understand why we have concerned ourselves with the denial of other peoples' fundamental significance. More specifically, rather than looking to history for verification that our actions are ill-founded, we would be better served by looking to religious valuations of the world that emerge from history, to understand why it has mattered to white Canadians that the Mi'kmaq be regarded as strangers. Perhaps in coming to such an understanding we will discover much more. If we regard history as the context out of which humans create notions of significance that reflect back onto historical existence, it follows that the context has the possibility of containing multiple meanings-and these then must bear upon the meaning of history itself. By approaching Acadian history from the perspective of religion, we may change our relationship with those things we "take for granted" and discover freedom from their restraint. As European Canadians, we may also find ourselves awakened to other meanings of the past (in this case, $\mathrm{Mi}^{\prime} \mathrm{kmaq}$ ), meanings that unveil a face of colonial history that whites have never had to encounter, nor withstand.

\section{II}

A religious analysis of any historical event requires some basic assumptions about the nature of religion from which discussion can proceed. This means initially constructing a definition of religion, and secondarily, locating the space in the event itself in which aspects of the religious are articulated.

Religion begins in history. History, as Jonathan Z. Smith has noted, "is the framework within whose perimeter those human expressions, activities and intentionalities that we call 'religious' occur." 21 Historical existence necessarily confronts the human being with physical, human, and psychic boundaries within which life must be lived in some meaningful fashion. Religion is the mode by which, as individuals and as communities, we both discover and construct such boundaries, in such a way as to sustain a sense of our own significance. ${ }^{22}$ It is, at its most basic, the way in which we define what it means to be a human being within any given context of time and place. 
The search for ways in which to believe one's existence matters raises the problem of identity. As Catherine Albenese has suggested, "our religion concerns the way we locate ourselves in space ... location is always social. It concerns our place among other human beings, and it means staking out a claim on the landscape of identity. ${ }^{23}$ The notion of identity, then, is directly related to the meaning of religion. It is through our sense of identity that the issue of origins, both ontological and historical, is raised. ${ }^{24}$

Human origins and identity emerge within patterns of human existence that we both imagine and perceive-patterns that to a great extent are understood in relation to their boundaries and what is situated beyond. The patterns we recognize as meaningful are those that are somehow differentiated from the rest of creation. We are contained in space that is thus "sacred," and surrounded by that which is chaotic and meaningless. It follows that the boundaries around what we regard as meaningful space are extremely precarious; they cannot be changed without producing a consequent change in the pattern itself. We might add that it is always in the realm of the chaos beyond the pattern that additional dangers reside, and as Eliade noted, these can variously include "demons," "the dead," and "foreigners." 25

The image of a meaningful pattern of existence that is flanked by what opposes such meaning is a predominant one in eighteenth- and nineteenth-century Acadian history, and so it is the relationship between religion and origins that will dominate this work. This, in turn, will require that attention is focussed upon the human experience of landscape, for it is in relation to particular "places" that human beings create patterns and derive, to a substantial degree, a sense of identity and meaning. ${ }^{26}$ It has been said that "to be rooted is the most important and least recognized need of the human soul." 27

For some time, scholars have been directing attention toward the relationship between native American religion and "place," noting that the religious life of America's aboriginal peoples can only be understood if one recognizes the basic interchange between mythical and geographical space. ${ }^{28}$ The concept of "place" has been conspicuously absent from much of our discussion of religion in the West, and this has amounted to a deficit that has limited what can be said and understood about ourselves. As Belden Lane has suggested, the drive toward recognizing and experiencing the sacred within the physical world we inhabit is something shared by all humans, and at the level of lived experience, Western peoples are not satisfied with the intellectual dualism inherited from the Enlightenment: "We are creatures ultimately discontent with the full-scale Cartesian separation of subject 
and object. It is the tangible ordinariness of everyday life that we want most to be informed by the holy." 29

In focussing upon the relationship between the human being and place, however, we confront a fundamental ambiguity. Landscape is experienced both as concrete reality and as symbol, so that any particular landscape exists in relation to a geographical location as well as to the human imagination. It is symbolic insofar as we construct rather than perceive it. On this level, landscape is not an objective "something"-distinct from our own being - in which history unfolds, but an interpretation or an expectation that both reflects and shapes human meanings. This process of interpretation is in one sense crucial for coming to think of a "place" as one's home..$^{30}$ Yet, in another equally critical sense, we must experience place on its own terms, unencumbered by expectation or convention. This form of experience without reflection is described by Edward Relph as an "authentic attitude of place" that must exist to some extent if we are to arrive at a notion of belonging to a particular place. This experience of belonging in turn hinges on a perception of continuity within a given place, and continuity is a necessity if we wish to maintain a "sense of reality." 31

Landscape, then, presses itself upon us as both objective and symbolic reality from which certain notions of origins and identity emerge. Within the realm of the more objective or "authentic" experience of place, we encounter still another source for the generation of identity: the other human beings who share the landscape with us. Through communicative exchanges with other humans, we locate our own humanity, discovering a capacity for self-understanding that leads to a process through which we define identity. The essentially "dialogical" character of the human being requires that we enter into a process of communication with others in order to first acquire the languages of human definition and, subsequently, to exploit them. ${ }^{32}$

Whether in respect to landscape or to human exchange, our sense of origins and of meaningful existence depend upon a somewhat ambivalent relationship with the human, geographical, and imaginal boundaries we experience. Yet a problem arises for us precisely because of this ambivalence. Between those boundaries we experience directly and those experienced through the imagination, and again between all boundaries and our sense of meaning, there exists a tenuous territory in which varying degrees of negotiation are required in order that our understanding of ourselves remains consistent with our experience of the world. This is the space in which religious symbols function. Symbols are modes by which we interpret the world, for they provide a congruent link between the way our lives are lived and our particular sense of meaning. ${ }^{33}$ At times we manipulate them to reflect reality, and at 
other times we manipulate reality to bring it to conformity with our symbols. We rely on them to meaningfully account for experience and, when they fail to do so, we become extremely uncomfortable as we are threatened by a sense of the chaotic. ${ }^{34}$ Religious symbols evoke cultural patterns that effectively circumscribe possible interpretations of experience, and consequently they provide human beings with manageable numbers of options for confronting the next moment of existence. ${ }^{35}$ Because of this function, they (and especially those, as Clifford Geertz suggests, whose referents are landscape or society| ${ }^{36}$ constitute principles of unity between experience and notions of significance, and are the predominant mode by which communities orient themselves. ${ }^{37}$

The unity provided by religious symbols is articulated in myths and mythic thought. Between any instant of experience and its interpretation, humans embark upon a symbolic process of negotiation that acquires conceptual and verbal structure through myth. ${ }^{38}$ In a sense, myths demonstrate "the religious character of the imagination, ${ }^{139}$ as they pivot on the human experience of boundaries. ${ }^{40}$ Yet they reveal more than the sacred structure of human creativity; they are statements about the fundamental value of human experience and they are constructed in terms of some or another originary meaning of the human being. As such, they reveal what is fundamentally meaningful within a community and, so, they are vehicles for the articulation and transmission of world view and cultural identity. ${ }^{41}$ Myths and mythic thought inhabit and structure the symbolic space between history and human religiosity and are consequently important focal points for a religious analysis of any moment of human experience. ${ }^{42}$

This discussion of Acadia will seek out the religious within the arena of origins. Entrance into the religious world of both the British and $\mathrm{Mi}^{\prime} \mathrm{kmaq}$ will be through the human necessity for continuity of place, and this will direct us toward the consequent patterns of meaning these New World peoples carved from both imagined and actual relationships to place, as well as dialogical relationships with other peoples inhabiting the same landscape. The tenuous ground between origins and experience will be explored in terms of the symbols that created unified fields of meaning, and the mythic worlds of both communities will constitute the media for fashioning a religious portrait of the period.

A word should be said at this point in respect to the locus of these mythic worlds, since "mythology" in this context will refer to a more broad body of sketches, records, and ideas than that to which the term is often applied. In its most strict sense, a myth refers to something that "narrates a sacred history; it relates an event that took place in primordial Time, the fabled time of 'beginnings'. In other words, myth 
tells how ... a reality came into existence. ${ }^{\prime 43}$ It may be justifiable, however, to focus on a wider array of materials as mythic, if we take as a point of departure something akin to Northrop Frye's assertion that "nobody can create, think or even act outside the mythology of his time. ${ }^{44}$ Given such an assumption, we can begin to discern threads of mythic thought woven throughout the fabric of a given culture. Since what are commonly called legend and folktale repeat in various forms the primordial structures of significance supplied by myth, these sorts of tales are vehicles that express mythologies and religious valuations. ${ }^{45}$ Within this realm, we may reasonably also include "historical legends, ${ }^{\prime 46}$ as well as literary works because, as Frye points out, literature might well be considered the offspring of mythology. Primordial valuations give rise to literature so that "mythical stories become structured principles of story-telling [and] mythical concepts ... become habits of metaphorical thought. ${ }^{47}$ Extension of the sphere of mythic material may be necessary in this instance in order to arrive at something better than a superficial analysis of the valuational structures that operated most particularly in the Acadian British community.

\section{III}

Before entering into a full discussion of $\mathrm{Mi}^{\prime} \mathrm{kmaq}-$ British relations in eighteenth- and nineteenth-century Acadia, it might be useful to contextualize the period in question within the more generic framework of the New World. In the first instance, this is to suggest the possibility that an analysis of the Acadian colonial event might contribute to a more synthetic understanding of the issue of alienation in the New World. Despite the tendency of Canadians to regard our history as in some sense exceptional, it is, nonetheless, a story firmly imbedded in post-Columbian motifs. As one historian has noted, "Canadian history in general is part of the story of the conquest of America, and the fate of the Beothuk, Huron, Blackfoot, and Kwakiutle people is not quantitatively different from that of the Aztec, the Maya or the Arawak. ${ }^{148}$ If this is true, then it follows that what is said in respect to the Canadian colonial experience could well have relevance beyond this context. The French historian Fernand Braudel has suggested that history might best be understood as something that simultaneously exists on a variety of collateral levels. Although he admits that the question of defining these temporal levels is one of creative speculation, he has, quite self-consciously, settled on three: those of (i) event history, (ii) the history of conjunctures, or social history, and (iii) structural history. ${ }^{49}$ Although time, he points out, is not a human creation, the way in which we choose to partition it is purely our own fabrication. Regardless of the 
number of measurements we impose upon it, all ultimately fall into one another so that, in a sense, to penetrate the meaning of any single level is to arrive at some understanding of them all. ${ }^{50}$ Likewise, to understand some measure of eighteenth- and nineteenth-century Acadia within the context of the longer duration of the New World may well be a means of gaining insight into the New World itself. We might add here, that since much of the following discussion will focus upon the nature and function of religious symbols in Acadia, the possibility of extending the conclusions reached at the end of this work beyond the actual context of the Canadian Maritime Provinces is clearly possible. As Mary Douglas points out in Natural Symbols, symbols are meaningless in isolation. Their meanings derive wholly from their relationships to the wider symbolic patterns in which they are contained:

The mind tends in some natural way to use the same symbols for the same situations ... the social relations of [human beings] provide the prototype for the logical relations between things ... whenever this prototype falls into a common pattern, there should be something common to be discerned in the system of symbols it uses. Where regularities in the system are found, we should expect to find recurring ... the same natural systems of symbols. ${ }^{51}$

In another sense, placing our shorter period within the extended context of the New World also reflects back upon the meaning of the event and conjunctures of colonial Acadia, conferring upon these an anatomy of religious significance at the outset of our discussion.

To begin we should take note of the fact that the phrase "New World" is, for instance, heavily laden with religious meaning. Despite the fact that Columbus insisted to his death that he had recovered an "old world" - that he had come upon a mass of "terra firma, well known to the ancients and not unknown, as the envious and ignorant would have $i^{\prime \prime 52}$-he nonetheless imagined the land in religious terms, as evoking the possibility of beginning again. In a letter he wrote in 1500 , he quoted from John's Gospel and the Book of Isaiah, writing of "a new heaven and a new Earth," and he described himself as God's envoy who had embarked upon "a new voyage to the new heaven and world." ${ }^{13}$ Although on one level, the "terra firma" he had found existed in space, the New World from its inception was located in the religious imagination. Edmundo $\mathrm{O}^{\prime}$ Gorman extended this point in his book The Invention of America, in which he has argued that the New World could not exist in fact because Columbus was incapable of conceiving of it.

In the wake of the Columbian event, European movement into the New World was permeated with the issues of human identity and 
origins. The act of colonizing, at its most basic, raised the problem of identity in terms of altering peoples' notions of being "at home." Settlement in a new region is always a fundamental exercise (in many respects tantamount to the primordial creation $)^{54}$ because "home" constitutes a locus of identity from which the world is interpreted ${ }^{55}$ The problem of identity for Europeans was rendered all the more dubious because their sense of being at home in Europe had become increasingly uncertain on the eve of their movement toward the Americas. The century that preceded the beginning of the Atlantic era was a period of "pessimism, cynicism, and despair." Populations had declined as a result of epidemics and warfare, economic activity had plummeted, and the intellectual climate had fallen into a state of inertia. ${ }^{56}$ In addition, continued defeat by the Turks in the southeast of the continent had compelled many to turn toward the Atlantic with a certain sense of dislocation. ${ }^{57}$

England in particular had suffered from a shortage of feudal income in the fourteenth and fifteenth centuries, and this had left members of the English aristocracy scrambling for ways to generate revenue so as to sustain dissolving social patterns and to stave off emerging class conflict. ${ }^{58}$ English expansion (as well as that of France and Holland) beginning in the sixteenth century occurred at a point of economic recession and concurrent population growth. Emigration, which began around 1590 (initially to Ireland, and then to the Americas), was seductive in this context because it proffered the possibility of "social mobility" - an accustomed way of European life that was dwindling markedly at home. ${ }^{59}$

In a sense, Europeans' identities were deconstructed before they set out for America. Upon leaving the continent, they embarked upon a venture in which they reconstructed themselves, but in the course of affirming an identity they forced non-Europeans to undergo their own deconstruction of meaning. ${ }^{60}$ In this process, native Americans came. to be regarded as a "counterimage" to the emerging colonial sense of identity-a designation that undercut the humanity of aboriginal peoples and set a stage for violence against them. The subversion of their human significance that accompanied the formation of colonial society forced them (as well as African Americans) into new modes of creativity through which their assaulted sense of meaning could remain vital. At a fundamental level, the colonized were compelled to reclaim their identity within the historical reality of violence, and they did so by re-imagining primordial constructions of human meaning that took precedence over colonial structures of power. In his recent book Sacred Revolt, for instance, Joel Martin has explored this phenomenon in relation to native American prophetic movements, and he has suggested 
that such movements have constituted constructive answers to the experience of oppression. Within the context of these phenomena, aboriginal peoples have sought to initiate new modes of being within the context of colonialism, and they have done so through renewed contact with their traditional spirituality. As such, they have constituted a religious means of reconstructing identity. ${ }^{61}$

The New World, as a long duration, is a place and time that is cloaked in religious significance. In the colonial world the problem of identity and origins is a problem that has been shared by all peoples. It is within this context that we must initially encounter colonial Acadia. We are entering into a historical analysis from the perspective of religion, and if at all successful, this analysis may carry us closer to understanding - and confronting - the problem of alienation, first, in eastern Canada and, then, by extension, in a post-Columbian world. Joel Martin also recently suggested that "learning how to think and live in this new world along with its various inhabitants . . continues to constitute a great religious project for every people in this world. ${ }^{\prime 62}$ In some sense, the following discussion aspires to be a "religious project."

\section{Notes}

1. Joe, Lnu and Indians We're Called, 64. Mi'kmaq has been used throughout this book in place of the more common spelling of Micmac. The former spelling has, in recent years, been generally adopted by this community as a more accurate rendering of the name.

2. The name Acadia refers to the modern Canadian provinces of Nova Scotia, New Brunswick, and Prince Edward Island. Dorothy Moore suggests that this nomenclature was adopted by the French in the early seventeenth century and based upon the Mi'kmaq word acadie meaning "fertile land." Marcel Trudel traces the name to the year 1524, when Verrazano navigated the eastern coast of North America between Florida and Newfoundland in search of a passage through the continent to Asia. Two maps created from Verrazano's account of this voyage were produced in 1527 and 1529 , in which the name Arcadia was ascribed to present-day Virginia. In the course of the following few decades, cartographers modified its location so that by 1566, Acadia had come to refer to the area encompassed by Nova Scotia and New Brunswick. Cf. Moore, "Multiculturalism: Ideology or Social Reality?," 86, and Trudel, The Beginnings of New France, xi, 6, 10.

3. Davis, The Micmac, $11 \mathrm{ff}$., considers evidence relating to the length of the $\mathrm{Mi}$ 'kmaq presence in the region and concludes that we are dealing with, at minimum, five thousand years of history.

4. The phrase "mutual products" is borrowed from Jennings, The Invasion of America, 328.

5. Miller, Skyscrapers Hide the Heavens, 275. Cf. pages ix-x, 268. Jennings makes a related assertion in The Invasion of America: "Any given Englishman at any given time formed his views in accordance with his purposes. Those who came for quick plunder saw plots and malignancy on every side. When the Indians were regarded as partners in 
profitable trade, they appeared less threatening. When they were wanted as soldiers for war against the French, the martial abilities of these demons were appreciated rather than decried ... the Englishman devised the savage's form to fit his function" (59).
6. Miller, 274.
7. Miller, $x$.
8. Miller, 278.
9. Long, Significations, 165.

10. Hall, The Silent Language, 165-166. I would also refer in this respect to Gardner's The Quest for Mind, 206, where he writes, "history is not a narration of dead facts and events. History . . . is an organon of our self-knowledge, an indispensable instrument for building up our human universe."

11. Pearce, Savagism and Civilization, viii.

12. This discussion of the nature of history and its study has been influenced by the Annales French school of historiography. The movement was the offspring of Lucien Febvre and Marc Bloch who founded the journal Annales d'histoire économique et sociale, in 1929. For an overview of the movement, see Fogelson, "The Ethnohistory of Events and Nonevents," 133-147. Paul Ricoeur has defined the Annales school against the background of "positivist history," noting that the French historians reacted against "the reduction of history to the collection and critique of documents . . the idea that the historical fact exists ready-made in documents ... then, the idea that explanation is limited to relating accidents among themselves following a chronological chain imposed by the documents; finally the idea that the individual is the ultimate relay of historical change and the limitation is the channel by which individual initiatives are propagated" (The Contribution of French Historiography, 473).

13. Cassirer. An Essay on Man, 184. In reference to his mentor Marc Bloch, Fernand Braudel reiterated this necessity to bring "life" to history: "History, for him, was never a game of sterile learning sufficient unto itself. I always seemed to be concerned above all with the explanation of man and society in terms of that one precious, subtle, complex gauge-time ... without which neither the societies nor the individuals of either past or present ever regain the appearance and warmth of life" (On History, 19).

14. See Heik, History and Myth, 23. For a discussion of the symbolic nature of historical sources, and the relationship between myth and history, see Cassirer, An Essay on Man, 174-175, and Heik, History and Myth, 1-4. In a related sense, Braudel also noted in the introduction to his Capitalism and Material Life, xi, that "general history always requires a model, good or bad, against which events can be interpreted. No theory, no history."

15. Cf. Fogelson, 141.

16. Febvre is quoted in Ricoeur, The Contribution of French Historiography, 9.

17. Hodgson, The Venture of Islam, 22-23. I became aware of Hodgson's work through Sullivan's excellent introduction and endnotes in Icanchu's Drum.

18. Eliade discussed this interchange between historical and religious existence in Images and Symbols, 32-33. Eliade noted, "Although it is true that man is always found "in situation," his situation is not, for all that, always a historical one in the sense of being conditioned solely by the contemporaneous historical moment. The man in his totality is aware of other situations over and above his historical condition." Through his exploration of native American religion, Sam Gill has noted this same dynamic. In Native American Religious Action, 153, he notes, "Religion is the human assertion of power to shape and create culture and history so that human life may acquire meaning, even beyond the limits of human existence."

19. See, for example, Wach, Introduction to the History of Religions, 164. 
20. See Jennings, The Invasion of America, 15.

21. Smith, Map Is Not Territory, 290.

22. For a number of variations on this simplified definition see Albenese, America: Religions and Religion, 3-9; Gill, Native American Religious Action, 153; Smith, Map Is Not Territory, 291; and Long, "Silence and Signification," 145-146.

23. Albenese, America: Religions and Religion, 5.

24. I was made aware of this critical connection in an introductory lecture given by Long, for "Myth, History, and Religion in African American Religion," a course he taught at Syracuse University in 1991.

25. Eliade, Images and Symbols, 37-38. For more detailed discussion of the distinction between order and chaos see Douglas, Purity and Danger, esp. 115-117, 145, and Tuan, "Sacred Space: Explorations of an Idea," 90-92.

26. Belden Lane provides a useful discussion of the relationship between place and identity in Landscapes of the Sacred, in which he notes: "personal identity is fixed for us by the feel of our own bodies, the naming of the places we occupy, and the environmental objects that beset our landscape." He adds that human beings are incessantly driven to "anchor meaning in place" (4-5).

27. Lane refers to this quotation of Simone Weil in Landscapes of the Sacred, 4. We might also note that scholars such as Gill have for some time been suggesting that an understanding of religious events can only be reached through consideration of a culture's "categories of place." See Gill, Native American Traditions, 20.

28. Cf. Lane, Landscapes of the Sacred, 46; Gill, Native American Religions, 29, 115.

29. Lane, Landscapes of the Sacred, 188. We could also note that Braudel, in his comprehensive history, The Mediterranean, pointed to the close relationship between geography and historical studies. More than half of the first volume fover three hundred and fifty pages) involved a detailed discussion of "The Role of the Environment," covering such topics as mountains, plateaux, hills, plains, climate, and seasons.

30. Donald Meinig, in the introduction to The Shaping of America, notes that historical geography assumes, in the first instance, that "Geography is not just a physical stage for the historical drama, not just a set of facts about areas of the earth; it is a special way of looking at the world. Geography, like history, is an age-old and essential strategy for thinking about large and complex matters" (xv). Lane describes landscape as "a construed way of seeing the world which is distinctive to a people ... [it is] an interpretive lens placed over an otherwise dull, placeless void" (Landscapes of the Sacred, 103), and McGregor adds, "nature, like other aspects of reality, is not simply perceived but socially constructed. By mythicizing our environment we convert it into a body of symbols, a kind of code which-like language-reveals both the ability to reflect and to coerce our experience of the world" (The Wacousta Syndrom, vii).

31. Relph, Place and Placelessness, 63-65.

32. The "dialogical" nature of humans is discussed by Charles Taylor in The Ethics of Authenticity, esp. 33, 47. Taylor defines these languages quite broadly, referring to "not only the words we speak but also other modes of expression whereby we define ourselves, including the 'languages' of art, of gesture, of love, and the like. But we are inducted into these in exchange with others. No one acquires the languages needed for self-definition on their own. We are introduced to them through exchanges with others who matter to us-what George Herbert Mead called 'significant others'" (33).

33. This interpretation of religious symbols is suggested by Clifford Geertz in The Interpretation of Cultures. Geertz believes that these symbols stabilize the force of both the human being's perceptions of particular realities as well as the ability to respond to 
given situations with appropriate emotions. They "formulate a basic congruence between a particular style of life and a specific ... metaphysic" (90, cf. 104).

34. Geertz, "Religion as a Cultural System," 7-14.

35. Gill points this out in respect to native American religion: "the symbolic process does not simply encode messages. It evokes the fundamental structures and patterns from the tradition and thereby establishes a meaningful form in which the future may unfold" (Native American Religions, 81).

36. Geertz, "Religion as a Cultural System," 14.

37. Albenese, America: Religions and Religion, 9.

38. This is a point made by Albert B. Friedman in "The Usable Myth," 39. Friedman is speaking of the "legendary," but I believe his discussion is applicable here because, as I will presently suggest, legend and folklore are essentially modes by which mythic motifs are reiterated in a different framework.

39. Sullivan, Icanchu's Drum, 22.

40. Cf. Eliade, Images and Symbols, 33.

41. Friedman stresses the relationship between myths and notions of significance in "The Usable Myth": "most Americans' valorization of experience is keyed to a mythology. Each of us carries around in his head a fragment of a collective national fantasy that assures him of his society's destiny and makes him accept his social obligations willingly" (41). Cf. Sullivan, Icanchu's Drum, 22, and Gill, Native American Traditions, 29. In reference to the role of myth in respect to cultural continuity, see Slotkin, Regeneration through Violence, 3: "The mythology of a nation is the intelligible mask of that enigma called 'national character.' Through myths the psychology and world view of our cultural ancestors are transmitted to modern descendants."

42. As Lévi-Strauss noted, "the purpose of myth is to provide a logical model capable of overcoming a contradiction" ("The Structural Study of Myth," 443).

43. Mircea Eliade, Myth and Reality, 5.

44. Frye, Divisions on a Ground: Essays on Canadian Culture, 185.

45. Eliade explores this relationship between myth and folktales in Myth and Reality, 201: "the tale repeats, on another plane and by other means, the exemplary initiation scenario." Cf. Popescu, "Eliade and Folklore," 85-87: "the historian of religion pushes himself back deeply in search of that mythology and that religious conception which express themselves in such oral documents and in such tradition [as folklore]." In respect to the function of folk tales and legend, Hugh Jansen has noted, "A Group's image of itself and its images of other groups are reflected in its folklore repertoire" ("The Esoteric-Exoteric Factor in Folklore," 43).

46. Hand, "The Index of American Folk Legends," notes: "Historical legends dealing with people, places, and events constitute an important body of material. This material will come partly, I suppose, from historical books; more of it will no doubt come from local historical and traditional accounts dealing with such diverse subjects as wars, skirmishes with the Indians ... natural disasters ... and other kinds of calamities associated with travel, industry, or commerce" $(219)$. When speaking of historical studies, we noted that a creative act occurs between the historian and the data at hand. Albert Friedman likewise suggested that "between the inert recorded fact and the interpretation that energizes it there is plenty of breeding and breathing space for the legendary" (Friedman, "The Usable Myth," 39|.

47. Frye, The Bush Garden, 32. Cf. Frye, Creation and Recreation, 27-28, and Frye, Spiritus Mundi, 71-72. In respect to the function of reading works of literature, Eliade wrote, "reading includes a mythological function, not only because it replaces the recitation of myths ... but particularly because, through reading, the modern man 
succeeds in obtaining an 'escape from time' comparable to the 'emergence from time' effected by myths ... reading projects him out of his personal duration and incorporates him into other rhythms, making him live in another "history'" (The Sacred and the Profane, 205).

48. Naylor, Canada in the European Age, xv.

49. Braudel, On History. In Braudel's configuration, event history refers to the history of "surface disturbance ... of short, sharp nervous vibrations" (3); the history of conjunctures refers to "economic and social history ... which lays open large sections of the past, ten, twenty, fifty years at a stretch ready for examination" (27); and structural history is "to be measured in centuries ... the history of the long, even the very long time spans, of the long durée" (27). Cf. Braudel, The Mediterranean and the Mediterranean World, 20-22.

50. Braudel, On History, 48. Alfred Crosby discusses the importance of situating historical studies within very broad contexts similar to the long duration of Braudel. In his book, The Columbian Exchange, Crosby comprehensively considers the biological changes brought on by the Columbian voyages and he suggests: "The first step to understanding man is to consider him as a biological entity which has existed on this globe, affecting, and in turn affected by, his fellow organisms, for thousands of years. Once we have placed man in his proper spatial and temporal context, we can begin to examine single aspects of events of his history with the assurance-or at least the hope-that the results will have a meaningful relationship to that context and will not merely send us off down the weedy little paths that lead from one antiquarian's gazebo to another" (xiii).

51. Douglas, Natural Symbols, 11-12.

52. This quotation appears in Washburn, "The Meaning of Discovery in the Fifteenth and Sixteenth Centuries," 12. Cf. O'Gorman, The Invention of America, 100.

53. Washburn, "The Meaning of Discovery," 19.

54. Eliade discusses the nature of settling as a cosmogony in The Sacred and the Profane, 31: "An unknown, foreign, and unoccupied territory /which often means 'unoccupied by our people') still shares in the fluid modality of chaos. By occupying it and, above all, by settling it, man symbolically transforms it into a cosmos through a ritual repetition of the cosmogony. What is to become 'our world' must first be created, and every creation has a paradigmatic model-the creation of the universe by the gods."

55. See Relph, Place and Placelessness, 83.

56. Nash, Red, White and Black, 27. Nash suggests that "it was 'New Worlds,' placed at the service of colonizing Europeans, that catapulted Europe out of a prolonged period of stagnation and regression."

57. See Wallerstein, The Modern World System, 48.

58. Wallerstein, The Modern World System, 46, 51.

59. Wallerstein, The Modern World System, 261.

60. I have borrowed this language of "deconstruction/reconstruction" from Long, who focussed on these ideas in his course "Myth, History, and Religion in African American Religion," 1991. Cf. Canny, "The Ideology of English Colonization," 597: "The sixteenth century colonizer was a proud and disdainful person, but he was also insecure and needed to remind himself constantly of his own superiority by looking to the imputed inferiority of others."

61. See Long, Significations, 170, and Martin, Sacred Revolt, 178-185.

62. Martin, Sacred Revolt, 185. 
This page intentionally left blank 
CHAPTER TWO

\section{LET NOT THY LEFT HAND KNOW WHAT THY RIGHT HAND DOETH}

$\mathrm{T}$

HE question of thinking and living in the New World began, for the British in Acadia, with a problem of continuity of place. Fundamentally, theirs was the problem of imagining continuity where there was none. Complicating the issue, however, was the fact that a great many British settlers were possessed of a sense of identity that had been in some measure disfigured and that they were consequently trying to recover. In most cases, the identity that they sought to preserve was of British origin.

The two principal groups of immigrants who came to comprise the population base and colonial administrators of Acadia were the Nova Scotia Yankees and the Loyalists. The first major influx of preLoyalist settlers arrived in Acadia in the early 1760s. ${ }^{1}$ These were, by and large, New England Puritans from Massachusetts, Connecticut, and Rhode Island, and most of them settled in Maugerville (on the east side of the St. John River) and in the area of the Chignecto Isthmus. ${ }^{2}$ These settlers had left New England before the movement for independence had gained momentum and they were loyal to Britain. ${ }^{3}$ Yet in moving to Nova Scotia they had weakened critical ties with families and friends, and the nature of their farmstead settlements had prevented the emergence of new communities. They were, as one writer has noted, "rootless people," ${ }^{4}$ and when, a few years later, the revolu- 
tionary war occurred, what was left of their ties with New England was virtually severed. One writer has suggested that this drove the immigrant Yankees into a collective crisis of identity out of which emerged, for example, the Nova Scotia Great Awakening, led by a young man named Henry Alline. ${ }^{5}$ Alline believed that New England and England, by corrupting themselves by violent confrontation, had subverted the meaning of the Protestant Reformation, and that it had fallen to Nova Scotia to assume New England's cosmic position in the world. ${ }^{6}$ The Yankees responded overwhelmingly to this notion of identity that merged British loyalty and Protestant mission. ${ }^{7}$

At the end of the revolutionary war, somewhere in the vicinity of thirty thousand Loyalists converged upon Acadia and settled, for the most part, at Shelbourne and Annapolis in Nova Scotia, and along the St. John and St. Croix rivers in what was to become New Brunswick. ${ }^{8}$ Most of these Loyalists were middle-class tradespeople or farmers who had been stripped of their American wealth and property. ${ }^{9}$ They had rejected the revolution, and in so doing, had turned away from the distinct character of what Marcia Kline calls "the New World environment." This rejection compelled the Loyalists to focus upon their European past and to regard themselves as people moving into a future that constituted a continuity with British culture. ${ }^{10}$ As Abraham Gesner explained in his nineteenth-century promotional book New Brunswick, With Notes for Emigrants, "the great number of loyalists that removed from the revolted states to Canada, New Brunswick, and Nova Scotia, have been succeeded by a population that is firmly attached to the Crown and laws of the Empire."11

The one million or so colonials who moved to British North America from various parts of the British Isles between 1800 and 1850 shared the Loyalists' desire to sustain a sense of cultural continuity with England. European social and economic structures had undergone massive alterations in the wake of both the industrial and agricultural revolutions in Europe, and the Napoleonic Wars had resulted in a recessionary period in England from which large portions of the population could not recover. For many, the move to British North America was an attempt to regain a standard of living that had been lost in the British Isles; they crossed the Atlantic holding fast to this desire to salvage an identity that had become threatened in Europe. ${ }^{12}$

The problem of continuity for the immigrants pivoted between the desire to conceive and speak of themselves as European, and the reality of not being in Europe. Acadia, in fact, did not appear as remotely familiar to these early colonials. A Scottish traveller in Prince Edward Island wrote home in 1821 to say, 
Everything in that Island, and, I believe, in all America, is new in some measure to every European, go from where he may; but the change is greater, and more distressing to an English family than to almost any other. ${ }^{13}$

Gesner later added,

The animals and plants, the climates, the oceans, seas, rivers, and lakes, were found to be different from those of civilized Europe. The heavens displayed new wonders to the astronomer, and all nature presented itself under forms with which the early voyagers were unacquainted. ${ }^{14}$

The British experience of Acadia and their problem of identity were primarily entangled in ambiguity, and their European heritage had taught them to be wary of ambiguity in both realms.

Prior to the seventeenth century in the West, human knowledge had generally been considered a product of a diversity of experience and impressions. The language that represented this knowledge was likewise evocative and grounded in the properties of figures of speech. ${ }^{15}$ This began to change as the rise of centralized monarchies led to the emergence of well-defined judicial codes. Technological improvement in the areas of war and manufacturing, as well as the expanded use of currency in Europe's commercial sectors, coincided with the rise of science and mathematics-both of which required a previously unwarranted rigidity of representation. This climate of linguistic precision gave rise to philosophical calls for language and thought that were purged of ambiguity, and led to movements of "linguistic reform" aimed at eradicating folk vernacular. ${ }^{16}$ John Locke warned that "those who pretend seriously to search after, or maintain Trust, should think themselves obliged to study how they might deliver themselves without Obscurity, Doubtfulness, or Equivocation, to which Men's Words are naturally liable."17

\section{Defoe suggested in The Complete English Tradesman (1725):}

The end of Speech is that we might understand one another's meaning. ... If any man was to ask me, which would be supposed to be a perfect style or language, I would answer, that in which a man speaking to five hundred people, of all common and various capacities, idiots or lunatics excepted, should be understood by them all in the same manner with one another, and in the same sense which the speaker intended to be understood. ${ }^{18}$

Donald Levine has suggested that the drive to eliminate linguistic ambiguity created a context in which the ambiguities of existence could no longer be represented. This contributed to a tendency toward 
the denial of "experiential" ambiguity, in which the possibility that human experience could contain multiple or obscure meanings became attenuated. ${ }^{19}$ The way in which human identity and origins came to be perceived in the West was an early benefactor of this movement away from ambiguity that has continued to permeate Western culture. Descartes's cogito ergo sum gave a structure of interiority to the human soul that effectively alienated it from the potentially kaleidoscopic significance of the historical situation of the body. It constituted an existential leap in supposing the human to be essentially reason "disengaged" from the variability of experience. ${ }^{20}$

Acadia's settlers were the heirs of this tradition that allowed for the generation of identity apart from the ambiguities of historical experience. Drawing upon this mode of self-definition, they set about imagining their British identity in the face of an environment that was anything but British. As Joseph Howe wrote in his poem "Acadia," the settlers "sought amidst Acadia's wilds to claim / A Briton's feelings and a Briton's name." 21 Eighteenth-century New Brunswickers, for instance, endeavoured to reconstruct the architectural landscape of England, and in places such as St. John and Essex, leaders of the colony built houses in imitation of British models. Ward Chipman's house was arrayed with English furniture and imported wall coverings, and George Leonard built an estate that was described by a contemporary as "exceedingly neat and in good taste [resembling] a gentleman's villa in Europe." The Anglican church in Fredericton followed suit, as an ostentatious imitation of Portland Chapel in London. ${ }^{22}$ The Loyalists also began constructing educational institutions at the end of the century, the curricula of which focussed upon classical languages, rhetoric, and English literature. Students were taught to imitate European models in their writing, and literature began to emerge from the context of this classical education that aped outdated British styles. In speaking of Acadian poets such as Joseph Howe and Oliver Goldsmith, Fred Cogswell has suggested that the apparent emotional drive that gave rise to their work was, at base, simply a "pathetic" desire to persuade the English that the British North American colonies were culturally identical to the "motherland."23 Outside of literary circles, British colonials clung with equal tenacity to their sense of continuity with an English identity. In his Observations upon the Importance of the North American Colonies to Great Britain (1825), Chief Justice Brenton Haliburton of Nova Scotia wrote, "The inhabitants of British America have no desire to change their national character, and will feel disposed to cling to the Mother Country as long as she fosters and protects them. ${ }^{24}$ A nineteenth-century promotional pamphlet written by a Nova Scotian by the name of Henry Bliss turned this sentiment toward the British, when he charged: 
let ministers then elevate and enlarge their views to the great circumstances in which they are placed. Let them endeavour to comprehend the whole dominions of Great Britain as one society, and the colonies for its integral parts, as much as if they adjoined Valentia or the Land's End.25

This idea that national-or individual-character could withstand changes in historical setting was a focus in Joseph Howe's campaign for responsible government in the 1830s. In a letter to Lord John Russel, for example, he asked,

Can an Englishman, an Irishman, or a Scotchman, be made to believe, by passing a month upon the sea, that the most stirring periods of his history are but a cheat and a delusion ... that the principles of civil liberty, which from childhood he has been taught to cherish and to protect by forms of stringent responsibility, must, with the new light breaking in upon him on this side of the Atlantic, be cast aside as useless encumbrance? No, my Lord, it is madness to suppose that these men, so remarkable for carrying their national characteristics into every part of the world where they penetrate, shall lose the most honourable of them all, merely from passing from part of the empire to another. ${ }^{26}$

Although it is true that these colonials were culturally equipped to imagine identity in isolation from their temporal and spatial situation, one must consider the question of how such a sense of meaning could be sustained when it was so dramatically inconsistent with their actual experience of the place. The answer, of course, is that at some critical level, it was not at all discordant. To imagine that they were unchanged in the process of "penetrating every part of the world," the British merely had to re-imagine any given place in such a way as to eliminate the potentially disconcerting ambiguity its novelty contained. In Acadia, they availed themselves of a traditional modality of regarding space and expanded it to the breaking point.

Yi-Fu Tuan has suggested that "wilderness" has traditionally been considered profane space in the West, with the "garden" representing the area of wilderness that has been re-fashioned for the exigency of human beings. Wilderness has consequently been regarded as something that must be re-created and the act of re-creation has contained many layers of significance. Each re-created wilderness has become a place where food can be produced; it has also become an indication of the expansion of social patterning; and finally, it has come to signify the conquering of profane space by that which is sacred. ${ }^{27}$

The colonial British confronted the alterity of Acadia armed with this appreciation of wilderness, and they extended the notion of chaotic or meaningless space to encompass the entire region prior to 
settlement. In some instances, this translated into a simple denial of the existence of anything on which a British sense of order had not been imposed. Early colonial cartographers, for example, curiously failed to record anything beyond the boundaries of European settlement. The first map of Halifax to receive wide circulation in England was a town plan drawn by Moses Harris in 1749. The plan depicted a British ship in harbour, and a palisade and five forts surrounding ordered streets, a church, an army barracks, a court house, and a governor's residence. Beyond the palisade, Harris drew two fruit trees, a porcupine, and a beetle of some variety. The forest and its wildlife were conspicuously absent, and nothing even suggested the presence of the aboriginal peoples who habitually hunted in the area. ${ }^{28}$

In most instances, however, nature was not avoided but endowed with dismal, sometimes even malignant, qualities. ${ }^{29}$ In 1827 , the missionary John West discussed the Loyalists' first encounter with New Brunswick's landscape, for example, and described the coast as "rugged, and the whole aspect of the country dreary and uninviting.... Nothing was to be seen but a few huts erected on the margin of a dark, immense wilderness. ${ }^{30}$ In New Brunswick as A Home for Emigrants, a promotional book published in 1860 , the author spoke of a colony characterized by savage wilderness and cultivated land: "we have brooks winding through dark ravines and rivers bounding through savage gorges or gliding peacefully through fertile meadows and happy homesteads," ${ }^{31}$ and in Howe's "Acadia" the same two images created a rather striking motif. The first was absolutely sinister-associated with the brutal massacre of white settlers by "red hunters" in the eighteenth century:

Around the cot the Indians form a ring

And songs of joy and triumph wildly sing

With horrid gesture and demonic strain

Then plunge into the forest depths again. ${ }^{32}$

The second was pastoral, percolating with images of creation in the nineteenth century:

But see, extending upon every side,

Her cottage homes! Acadia's noblest pride;

There honest Industry, by daily toil, Covers with fruits and flowers his native soil;

And calm contentment, with an Angel's air,

And humble hopes, and smiling joys, are there. ${ }^{33}$

Thomas Chandler Haliburton emphasized the value of re-created landscape in his work, The Old Judge, when an "unnamed English traveller" described his arrival at Halifax-Dartmouth: 
The first object that met our view was the picturesque little church that crowns the cliff overlooking the village and haven of Falkland. ... The entrance to this noble harbour, the best, perhaps, in America, is exceedingly beautiful: such portions of the landscape as are denuded of trees exhibit a very high state of cultivation .... and the national flag and the British sentinel bear testimony to the power and extensive possessions of dear old England. ${ }^{34}$

The only landscape that was regarded as significant by British colonials was that which had been re-shaped for their needs and according to the values of their European culture, which they called "civilization. ${ }^{\prime \prime 5}$ For a group of people engaged in an imaginative process of selfcreation (and for a people situated in a context with a disruptive potential) the imperative for extending civilization became an indispensable tool for re-shaping the world. With it, they could reassure themselves that European colonials were not, as an Italian writer once put it, the "offscourings of the nations," ${ }^{36}$ but agents of a historical process, through which human history was moving toward a more perfect state. "Developing the resources of a country," wrote W. R. M. Burtis, in 1860,

is not a single factor or attainment, but a successive and never ending series of facts or achievements, reaching far into the future.... Our sense of what may be done is improved and enlarged by our acquaintance with what has been done. The art-triumphs of the last half-century, instead of appearing to our lives as defining the reach of the human intellect, and the adaptation of the elements and materials of the earth to the purpose of human life--of social and moral progress-creates a belief in the illimitable application of natural laws-in the still greater triumphs of human reason, and the still higher destiny of the human family. Each successive attainment becomes, in turn, a stepping-stone from which the children of light may take a bolder flight into the regions of discovery. ${ }^{37}$

Civilization and progress became symbols through which the colonial experience of being displaced could be reconciled with the notion of being steadfastly European. For these symbols to remain effective, much rested on the re-creation of the Acadian landscape, and that required unobstructed access to the land itself. Of course, there were a great many other people on the land who were not entirely enraptured with what the missionary John West described as the "diffusion" of the "light of science and the arts"; 38 but the British dealt with the potential impediment they posed by ignoring their presence, or by conceding to them as little attention as possible.

By the Treaty of Utrecht in 1713 , France had relinquished control of Acadia. Within the text of the treaty itself, the Mi'kmaq were not even mentioned, ${ }^{39}$ and from the colonial point of view this was to become a preferred method of dealing with aboriginal peoples. When, 
for instance, in 1761, the English Board of Trade instructed Nova Scotia's governor, Jonathan Belcher, to issue a proclamation forbidding encroachment on $\mathrm{Mi}^{\prime} \mathrm{kmaq}$ lands, he obediently drew up the document that stated, among other things,

Wherefore in dutiful Obedience to His Majesty's Orders I do accordingly publish this proclamation in His Majesty's Royal Name, strictly enjoining and requiring all Persons what ever, who may either willfully or inadvertently have seated themselves on any Lands so reserved to or claimed by the said Indians, without any lawful Authority for doing forthwith to remove therefrom. ${ }^{40}$

Belcher subsequently decided to refrain from issuing it "at large." After reminding the board in a private letter, that the Mi'kmaq had ceded all claim to Acadia by the Treaty of Utrecht, he went on to explain, "If the Proclamation had been issued at large, the Indians might have been incited ... to have made extravagant and unwarrantable demands, to the disquiet and perplexity of the New Settlements in the Province." ${ }^{\prime 41}$ We might compare the circumstance surrounding the dissemination of Belcher's proclamation with those of another proclamation issued in 1758 and again in 1759, in which Belcher's predecessor Charles Lawrence offered substantial incentives for immigrants settling in the colony. Both versions of the document were widely circulated in the New England colonies. ${ }^{42}$

Colonial governments generally resisted $\mathrm{Mi}{ }^{\prime} \mathrm{kmaq}$ pressure to buy land back for them from colonial interests, and the most acute instance of this resistance occurred in Prince Edward Island, where the British government had granted the entire colony in 1767 to absentee proprietors. Refusal to spend public money on securing $\mathrm{Mi}^{\prime} \mathrm{kmaq}$ title to land was a continual problem in Prince Edward Island. In 1843, for instance, the Assembly set aside fifty pounds to buy Murray Island for the native population, but the purchase never occurred. In 1860, Joseph Howe appeared at Land Commission hearings in Charlottetown and recommended that Lennox Island be purchased for the region's $\mathrm{Mi}^{\prime} \mathrm{kmaq}$. The Assembly, however, refused to pay the price set by the island's owner, R. B. Stewart. The $\mathrm{Mi}^{\prime} \mathrm{kmaq}$ in that province consequently remained without legal title to any part of the island until $1870 .^{43}$

Land on which the Mi'kmaq were permitted to remain was generally relinquished by the colonials because of its inaccessibility or its relative lack of a resource base. Although the government of Prince Edward Island did not buy any land for its aboriginal population, in the late eighteenth century it gained permission from the proprietor James Montgomery to allow the $\mathrm{Mi}^{\prime} \mathrm{kmaq}$ to settle on Lennox Island-an area furthest removed from white settlement and covered, to a substantial degree, by "barrens and swamp." ${ }^{44}$ In 1801, the New Brunswick 
government likewise chose to grant a particular petition because, as the surveyor-general noted, it "appears to be reasonable and can interfere with no settlement." 45 In Nova Scotia, land surrendered to the Mi'kmaq was "chiefly barren, and [situated in] spots removed from the sea-coast." 46 In addition to reserving only the poorest quality of land for the Mi'kmaq, colonial governments made concessions often with a stipulation that native communities were not to request any further grants. In New Brunswick, for example, the government entered into an agreement with the $\mathrm{Mi}^{\prime} \mathrm{kmaq}$ of the St. John River area in 1807 by which a parcel of land was to be purchased with public moneys on the condition that,

they the said Indians do consider the same as full satisfaction for all claims or pretensions which they may have hithertofore had or which they may now conceive themselves to have to the said Maductic Point or to any other land upon the said River. ${ }^{47}$

Yet legal recognition of the $\mathrm{Mi}^{\prime} \mathrm{kmaq}$ presence in any location rarely extended to the settler population. Squatting and various forms of encroachment were endemic and uncontrolled. ${ }^{48}$ In 1783 , for example, John Julien obtained a licence of occupation from the government of Nova Scotia for twenty thousand acres on the Miramichi River. Between 1785 and 1807 his band repeatedly requested that the licence be confirmed in the face of excessive encroachment by white settlers. The result of their continued effort was that Eel Ground las well as three smaller tracts along the river) was reserved for them in 1807; but of the original twenty thousand acres, only ten thousand remained at this point. ${ }^{49} \mathrm{~A}$ few years later the missionary Walter Bromley reported that he had spoken with a chief whose father had cleared two hundred acres of land at various locations and times in Nova Scotia. All of it, he noted, had been appropriated by white settlers. ${ }^{50}$ At the turn of the nineteenth century a Mi'kmaq community was granted four thousand acres of land on the eastern side of the Wagamatcook River in Cape Breton Island. By the 1860 s, all that was left of the tract was seven hundred acres containing a village, a burial ground, and a grove of sugar maples. ${ }^{51}$

Whites stole Mi'kmaq land, and they also appropriated timber and hay and built dams with little regard for the reserve land they flooded. Abraham Gesner admitted, in the mid-nineteenth century that, "As the title is not in the Indians, they have no power to prevent trespasses; and the result has been, that the lands set apart for their benefit are plundered for their most valuable timber, and the most fertile places of ground occupied by unauthorized persons." ${ }^{52}$ Although colonial governments intermittently passed legislation intended to protect $\mathrm{Mi}^{\prime} \mathrm{kmaq}$ land, these bills were not enforced because, as Lieutenant-Governor William Head was advised in 1848 , "it would not now be possible to 
eject the occupants, even if in itself such a measure were desirable." ${ }^{53}$ The fact was, this "measure" was not deemed to be desirable in any colonial circles. As one Fredericton newspaper noted in 1844, "the extensive tracts of valuable land reserved for the Indians in various parts of the Province tend greatly to retard the settlement of the Country. ${ }^{\prime 54}$ In 1843 , a New Brunswick government committee report sug. gested that "Industrious poor Squatters" had improved the land on which they had settled and should not be forced to remove themselves; ${ }^{55}$ and Abraham Gesner told potential British immigrants that if they chose to become squatters (a group he described as "a very remarkable class of persons") they could safely assume that title to the land could be later obtained at very little cost. ${ }^{56}$

Despite these wholehearted attempts to ignore the Mi'kmaq, the British could not help but notice that the extension of civilization had contributed to the physical declension of the native population. Throughout the process of colonization, dispossessed $\mathrm{Mi}^{\prime} \mathrm{kmaq}$ constituted a presence that could not be entirely avoided, and this appears to have encumbered many British with a threatening sense of guilt. As the writer Douglas Huygue noted in the introduction to his novel The Nomads of the West (1850), "We rear the germ of a great city without casting a thought on the generation crumbling beneath." ${ }^{\prime 57}$ Gesner expressed this sentiment repeatedly in his reports to the Nova Scotia government in the late 1840 s, bemoaning, for instance, the fact that

They have been supplanted by civilized inhabitants, and in return for the lands for which they were the rightful owners, they have received loathsome diseases, alcoholic drink, the destruction of their game, and threatened extermination. ${ }^{58}$

In some cases the British were able to creatively confront this sense of transgression by attributing what they perceived to be the immanent disappearance of aboriginal peoples to the $\mathrm{Mi}^{\prime} \mathrm{kmaq}$ themselves, or to the ultimate process of the extension of civilization of which the British were agents, not initiators. At this level the Mi'kmaq were regarded as a vestige of a community whose significance had waned in the working out of human progress. The language employed to speak of them was laden with images of an eclipsed meaning, with words like "remnant" and "remains" pointing to their significance as lying firmly in the past. Thus, Huygue wrote, "Look at that shrivelled remnant of what was once a powerful, energetic man"; and the Nova Scotia government was warned by a committee in 1801 that "all the pecuniary resources of the Province would ... be found inadequate to the support of this Remnant of the Mickmack tribe." ${ }^{19}$ John West called the $\mathrm{Mi}^{\prime} \mathrm{kmaq}$ "a remnant of a people, who were once sovereigns of the soil"; ${ }^{60}$ the Nova Scotian described a chief present at the Halifax 
celebration of Queen Victoria's marriage as "a remnant of his tribe"; Gesner noted, "At present time, there are the remnants of two tribes in New Brunswick"; ${ }^{62}$ and Moses Perley, in his 1841 report to the lieutenant-governor of New Brunswick, called them "the scattered remains of the once proud and mighty," and the "remnant of an illfated race." 63

Those Mi'kmaq who "remained" a presence in Acadia were often considered to have ceased to be legitimate aboriginal peoples. Speaking of the Mi'kmaq at Restigouche, Moses Perley admitted, "The old people ... struck me as possessing very little Indian blood, while the younger portion are so fair, as to raise a doubt whether they should be styled Indians at all ... each generation appears fairer than the preceding." ${ }^{64}$ In addition to this physical transformation, some also perceived a cultural transformation that had effectively separated the $\mathrm{Mi}^{\prime} \mathrm{kmaq}$ from their past. The sportsman Campbell Hardy noted, for instance, "Few Traditions exist among the Nova Scotian Indians concerning the habits and wars of their forefathers." 65

The fact that Acadia's native peoples had nearly disappeared was, for many colonials, a clear consequence of their refusal to co-operate with the unfolding of progress. ${ }^{66} \mathrm{An}$ article in the Nova Scotian in 1846 claimed that the $\mathrm{Mi}^{\prime} \mathrm{kmaq}$ were devoid of "foresight" and naturally lazy, and had consequently failed to come to an enjoyment of the benefits of civilization-"arts, science, and laws." ${ }^{67}$ That they were primordially lazy was a common theme. In a report from the New Brunswick government to the Colonial Office in 1838, for instance, native peoples were described as "naturally indolent." ${ }^{68}$ In 1854, William Chearnley commented that "their character is such that I fear we shall always find them to be a people unwilling to work," and a few years later he added that the $\mathrm{Mi}^{\prime} \mathrm{kmaq}$ were "destined to live a roving life . . almost wholly dependent on charity. ${ }^{\prime 69}$ Gesner claimed that

although their outward appearance has undergone alteration, and necessity has compelled them to conform more or less to the present condition of the country, in their social state they remain unchanged, and every effort to bring them to a state of civilization has proved abortive. ... They have been instructed in the arts and in agriculture; but no sooner were they liberated from their masters, than they returned to the haunts and habits of their forefathers, and became the most depraved of all their race. ${ }^{70}$

The historian Alexander Monro informed his readers that from 1763 onward

every possible encouragement has been held out to these people by the local governments; large tracts of land have been set apart for their use in different parts of both Provinces, and the Legislatures 
have, whenever their necessities have required it, granted large sums ... for their relief . . . some of them have been induced to settle.... They are sometimes employed in the lumber woods. . . But the predilections for hunting, basket making, and the wigwam, prevent them from pursuing other avocations for any length of time. ${ }^{71}$

There were times when the British were not so inclined to afford full responsibility for the demise of the native community to the Mi'kmaq themselves, but were also reluctant to attribute it to their own community, and at these moments they identified the ultimate causes as "civilization" and "progress," as though these had some subjective existence apart from their imagination. So Perley claimed, when he wrote, "the survivors of the ancient possessors and lords of the country ... are fastly yielding to the calamitous fate which so often befalls uncivilized man." 72 The incompatibility of aboriginal peoples with civilization was a recurrent myth, and one that Huygue explored in the conclusion of his book, Argimou: A Legend of the Micmacs. At their parting, the British officer Edward Molesworth implored his friend Argimou (a Mi'kmaq chief) to accompany him back to England, but the chief declined the invitation. Although the two men had been friends in a context of separation from their respective societies, this could not continue outside that context: "Brother, said [Argimou] with pathos-it can never-never be. When you take the moose from the woods and keep it among the settlements of the pale-faces, it will pine away and die. ${ }^{\prime 73}$ The moose motif was a common device in nineteenthcentury writing dealing with the Mi'kmaq. The Reverend John Sprott, for instance, made use of the motif in an article published in the Nova Scotian, April 6, 1846: "The approach of the white man, and the march of improvement, have sealed their doom. ... Now we seldom see a moose or an Indian." 74

Whether it was considered to be the fault of the Mi'kmaq themselves or of progress, the fact that the Mi'kmaq were facing annihilation was rarely considered to be a result of the attempt by this specific group of Europeans to re-create an equally specific region of the New World. At this level, the native community was acknowledged as having once had meaning in the world it inhabited, but that world had given way to one of greater significance, and native peoples were unavoidably victims of this human movement. At another level, however, the link between the process of colonization and the physical destruction of the Mi'kmaq could not be dismissed so easily, and as a consequence, many colonials sought to reconcile the fact of dispossession with the idea of civilization on which they were suspending their own notion of meaningful existence. They suggested that the $\mathrm{Mi}^{\prime} \mathrm{kmaq}$ could be saved from their impending destruction through a concerted effort on the part of the British to re-make them, just as they were 
re-making the land. For many, this appeared not just as a possible course of action but a responsibility.

It is important to recognize that for the colonial British, the Mi'kmaq were essentially part of the wilderness and were possessed of the same qualities attributed to "wild" Acadia. When the landscape of Acadia was first encountered, it had been a country "wrapped in the gloom of perpetual fog, ${ }^{\prime 75}$ and had subsequently been re-made as a place of "calm contentment, with an Angel's air." 76 The Mi'kmaq had been discovered in the margins of the darkness that had been Acadia, and had remained a part of it. As the poet Thomas Daniel Cowdell wrote in the first years of the nineteenth century,

From shores, where howls the savage bear,

And tawney tribes of Indians are;

Where quiet, endless forests grow,

That never felt the woodman's blow;

A continent rul'd by extremes

Of frigid cold and flaming beams;

Far distant from Europa, fam'd,

And which, like her, may yet be tamed. ${ }^{77}$

John West echoed Cowdell's sentiments when he noted, "Nothing was to be seen but a few huts erected on the margin of a dark, immense wilderness, and occasionally some of the natives, clothed principally with the skins of animals."78 Their association with the wilderness was consistently emphasized throughout the colonial period, as they were variously characterized as "sons of the forest," "red brethren of the wilderness," ${ }^{80}$ or "children of the forest." 81 On one occasion, the Nova Scotian described them as "nature's gentlemen," and on another referred to "Isodore, the chief of Musquodoboit," who had recently died, as "this venerable old hemlock, through whose branches the storms of ninety years had whistled." 82

Yet the Mi'kmaq were not only part of the wilderness; they also shared in its sinister qualities. Thus, Howe's Indians in the poem "Acadia" emerged from the "forest depths" to embark upon a savage massacre of a family of settlers. ${ }^{83}$ Moses Perley identified the Mi'kmaq as "formerly a very fierce and powerful tribe" of people who were also "deceitful," 84 and Alexander Monro recalled for his readers a time when

Their ferocious habits, their physical strength, their warlike propensities, their agility and skill in the use of their weapons, and their deadly opposition to every other race, rendered it an extremely hazardous undertaking for a European to land on their shores, much more so to penetrate into the country ${ }^{85}$ 
Oliver Goldsmith, the first Acadian colonial poet to receive serious international critical acclaim, identified the Mi'kmaq with "beasts of prey" lurking at the peripheries of his "Rising Village." 86 Gesner described what he considered to be prototypical $\mathrm{Mi}^{\prime} \mathrm{kmaq}$ behaviour during a massacre of eighteenth-century white settlers in the following manner:

In the dark and silent hours of the night, when the peaceful inhabitants of the villages were wrapt in slumber, or when the sentinel trusted to the distance between himself and the enemy, the savages were creeping upon them like serpents, sometimes drawing their bodies on the ground, at other times standing erect and imitating the appearance of trees or other common objects, until the warwhoop was raised, when all rushed forward to the indiscriminate and diabolical slaughter of men, women, and children. These fiendish acts and terrible tortures they inflicted on their prisoners, formed the dark pages of Indian history. ${ }^{87}$

Although the British took some pride in having subdued the savage tendencies of the "Indians," many remained uncomfortable with the fact that the Mi'kmaq were situated at the margins of civilizationthey had not shared in the "smiling joys" that the land itself had acquired ${ }^{88}$ In fact, they were languishing as a result of progress, rather than reaping its benefits. The potential ambiguity of civilization was obvious in the demise of the native community, and this rendered the value of the notion at least questionable.

The solution for some was to re-fashion the $\mathrm{Mi}^{\prime} \mathrm{kmaq}$ in the image of European colonials. The premise was that if they could be "civilized" and so, made to think and act like whites, the value of progress would remain intact. Thus, the Nova Scotia government was told by its Commissioner of Indian Affairs in 1848 that throughout the preceding century of colonization little effort had been made "to civilize the race, now brought to the lowest depth of misery and despair," and that the Mi'kmaq had been subjugated "not to redeem but to destroy." ${ }^{89}$. During the same period, the New Brunswick legislature was warned by its own commissioner:

If the scattered remains of the once proud and mighty, possessors of the whole land are allowed to continue in a state of degradation or ruinous decay, a mountain of reproach will rest on those who have supplanted them as lords of the soil without imparting any equivalent, therefore supplanting only to destroy instead of to civilize and save. 90

In a letter published in the Christian Messenger in 1855, the missionary Silas Rand likewise bemoaned the fact that whites had turned away from their "obligations" to the Mi'kmaq, who 
eats and sleeps in the midst of confusion-bundles, blankets, kettles, papooses and dogs tumbelled pell mell, and huddled together amongst smoke and filth and vermin. ... We seize upon their country. We rob them of their lands. We drive them from their homes.91

The idea of rendering native culture obsolete through the imposition of European culture existed as a possibility because of the nature of human progress. European culture was regarded as a stage in the development of humanity that had logically proceeded from earlier forms, and the $\mathrm{Mi}^{\prime} \mathrm{kmaq}$ were viewed as simply having had the misfortune of not yet progressing to that stage. Hence, they were underdeveloped humans who could be induced to engage in the process of progress. As one writer noted late in the period, "We chide them and wonder at them, because they cannot learn in a few years what we have gathered from the experience of many centuries. We might as well expect infancy to join the rigourous sports of boyhood." ${ }^{\prime \prime 2}$ The myth of the $\mathrm{Mi}^{\prime} \mathrm{kmaq}$ as childlike was employed frequently throughout the period. The Free Press, for example, described them as "infants as regards defect of knowledge in their new situation, ${ }^{\prime \prime 3}$ and Moses Perley suggested that they should be "treated as wards of the sovereign." Perley also wrote of Mi'kmaq guides in the London Sporting Review of 1839, and described them as "lynx-eyed, active, half amphibious Indian boys, ${ }^{\prime 95}$ and the Halifax Reporter, commenting on the city's reception for the Prince of Wales in 1860, defined those whites who had been present on the occasion as "ladies and gentlemen," while referring to the Mi'kmaq as "children of the forest."

For the British, the "advancement of cultivation in the wilderness ${ }^{\prime 97}$ was an indication of progress in colonial Acadia. It was logical, then, that the "civilization" of aboriginal peoples would require their adoption of agricultural modes of subsistence, and many whites called for a concerted effort on the part of their contemporaries towards educating the $\mathrm{Mi}^{\prime} \mathrm{kmaq}$ in agricultural methods and technology (as well as the English language). New Brunswick's provincial secretary announced early in the period, "If they are willing to learn, we are ready to teach them ... all the methods of agriculture by which an unfailing Subsistence is secured to all civilized and industrious Planters. ${ }^{\prime 98}$ The government of Nova Scotia passed an "Act to Provide for the Instruction and Permanent Settlement of the Indians," in 1842, ${ }^{99}$ and in 1864, the province's commissioner Samuel Fairbanks recommended that any Mi'kmaq who settled permanently "should be treated in every respect as a British subject ... he should be allowed to vote at elections." 100

Despite the ostensible desire to see the native population "civilized," the historical situation of the Mi'kmaq during the period points to a fundamental discrepancy between the British language of inclusion 
and their practice. Far from striving to provide native peoples with access to the "comforts of refined society," the colonials appear to have been engaged in their absolute dissolution. With the advent of substantial immigration into Acadia in the mid-eighteenth century came rapid and dramatic changes in the world inhabited by the $\mathrm{Mi}^{\prime} \mathrm{kmaq}$. The loss of land has been noted already. It should be noted, however, that a good deal of this land had been prime hunting and fishing areas on which the $\mathrm{Mi}^{\prime} \mathrm{kmaq}$ supported their communities prior to the influx of settlers. After 1750, native peoples were increasingly alienated from these regions, and a general depletion of game (especially moose) occurred throughout the colonies. ${ }^{101}$ As early as the 1760 s, segments of the $\mathrm{Mi}^{\prime} \mathrm{kmaq}$ community were beginning to suffer from deprivation, ${ }^{102}$ and by the turn of the century a majority had become impoverished. ${ }^{103}$ Relief payments to offset this forced situation of privation began around 1800, but were insufficient or offered only in times of crisis. During the first year of relief payments in Nova Scotia, for instance, one government agent reported that despite the distribution of goods, the community at Antigonish was in a "miserable condition," and many were without any clothing whatever. ${ }^{104}$ In 1812 , rumours of a possible alliance between the St. John $\mathrm{Mi}^{\prime} \mathrm{kmaq}$ and the Penobscot on the American side of the border compelled the New Brunswick Council to make relief payments in return for assurances of $\mathrm{Mi}^{\prime} \mathrm{kmaq}$ neutrality. Money for supplies continued to be provided on an ad hoc basis until 1814, when the crisis appeared to have subsided. ${ }^{105}$

The physical state of the Mi'kmaq degenerated continually throughout the first half of the nineteenth century. Government documents consistently demonstrated that they were without food and clothing and were suffering from endemic disease. In the 1840s, Moses Perley informed the New Brunswick Assembly that

I learned on enquiry from many elderly people, who stated themselves to be childless, that they had had from 8 to 12 Children each, who had died in infancy from Measles, Whooping Cough, Scarlet Fever, Croup, Typhus, Small Pox, and a variety of other Diseases, to which Children are subject. ... During my visit to the Miramichi the Children were suffering dreadfully from Dysentery, and while at Burnt Church Point a death occurred almost daily. ${ }^{106}$

In 1831 , the Mi'kmaq at Rawden, Nova Scotia, possessed ten blankets for fifty people and in 1834, those of Windsor were naked and without shelter. ${ }^{107}$ Between 1846 and 1856 , the $\mathrm{Mi}^{\prime} \mathrm{kmaq}$ at Digby were said to be dying "for want of food and sustenance," those in Cape Breton and at New Glasgow were "ready to drop from hunger," and those at Pictou were "actually starving [and] crying for food."108 
Nova Scotia Mi'kmaq Population ${ }^{109}$

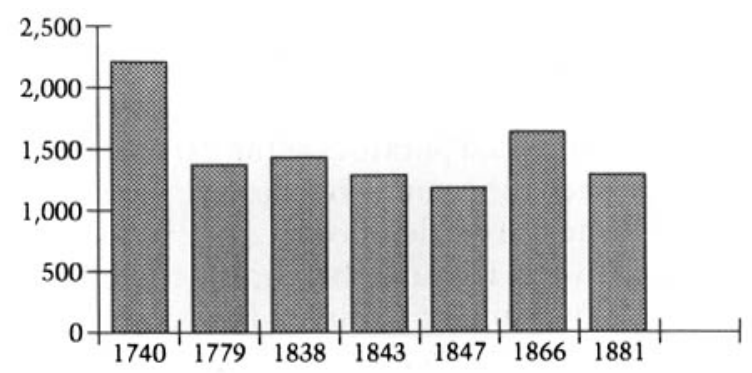

Nova Scotia White Population ${ }^{110}$

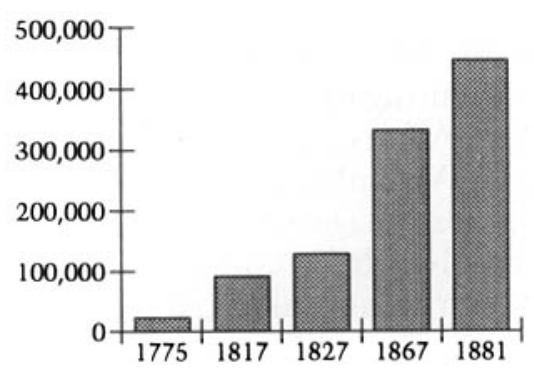

While whites were calling for their "civilization" in order to share in the benefits of progress, they appear to have been doing pitifully little to promote the possibility. In the 1790 s, the Mi'kmaq were encouraged by the Nova Scotia government to produce "baskets, axe-handles, shingles, and staves"-products that the majority of recent immigrants were unable to buy. ${ }^{111}$ In New Brunswick, where logging was a more lucrative enterprise than farming, ${ }^{112}$ very few employers chose to hire native labourers despite the fact that they were reputed to be "excellent axemen." Walter Bromley reported in 1822, that at Chedabucto Bay in Nova Scotia,

where the Indians have been in constant habit of fishing and supplying the white fishermen with their manufactures, peltry \&c. for several years, they have been expelled in the most brutal manner from that fishing ground by the white people, who entered their camps, defiled their women, abused and beat the men, and, in fact, conducted themselves in such a manner as to prevent the possibility of their remaining any longer. ${ }^{113}$ 
Those $\mathrm{Mi}^{\prime} \mathrm{kmaq}$ who wanted to farm in Prince Edward Island could not obtain land, and elsewhere, encroachment and an inability to secure credit from agricultural suppliers weakened the possibility. ${ }^{114} \mathrm{Up}$ to 1840 , relatively little government assistance was provided for potential farmers, and after 1840, such aid was inconsistent. Little technical advice was provided, and seed potatoes often arrived too late in the season for planting or had to be eaten by the starving prospective farmers. ${ }^{115}$ When the Prince of Wales donated fifty pounds to assist the Mi'kmaq of Prince Edward Island in beginning to farm, the money was used by the colonial government to buy old muskets. ${ }^{116}$ In a near fitting finale to the period, William Chearnley decided to abandon the notions of civilization and settlement, and spent his entire grant of 1859 on blankets (of which he bought twelve hundred and eighty-six). A year later, he boasted of how many second-hand greatcoats he had purchased with that year's allotment. ${ }^{117}$

Perhaps the colonial figure who appeared most committed to the actual welfare of the $\mathrm{Mi}^{\prime} \mathrm{kmaq}$ during the period was Moses Perley, who was Commissioner of Indian Affairs in New Brunswick during the 1840s. In his 1841 report to the Assembly (from which many references have already been drawn), Perley suggested that the "civilization" of the Mi'kmaq could be achieved without undue difficulty if sufficient funds were channelled into their communities and if contact with British settlers were promoted. ${ }^{118} \mathrm{He}$ recommended that the office of superintendent be created to oversee the education and settlement of native peoples in the province, that government-funded health care be provided for the disease-ridden population, that land be held communally on reserves, that unused land be leased to pay for education in trades and for health care, and that native settlements be located in close proximity to those of the colonials so that schools might be integrated. ${ }^{119}$ These very tangible suggestions were not welcomed by the colonial government, and most were ultimately ignored. In 1844, the government decided to attempt to sell reserve land to settlers who were illegally squatting, and announced that

the monies annually arising from the sale and leasing of the said Reserves, and also from the rents, issues and profits thereof, after payment of expenses aforesaid, shall be applied to the exclusive benefit of the Indians. ${ }^{120}$

Perley was intensely critical of the scheme, warning that squatters would never be induced to pay for the land on which they were settled, but his concerns were disregarded. The plan failed, as Perley had predicted. By 1848, he had been silenced by the government and was informed that he was no longer in their employ. ${ }^{121}$ It appears that the 
services of one who-regardless of motivation-actively promoted the welfare of the Mi'kmaq and their interaction with whites had probably never been required at all by the colony of New Brunswick.

\section{Notes}

1. Jeanne Guillemin notes that the settlement of Nova Scotia substantially followed the expulsion of the Acadians that began in 1755. It was at this point that the British government systematically embarked upon drawing settlers into the region in order to exploit the land that had been cleared by the removal of the French population. Although Guillemin suggests that the number of Acadians involved in the expulsion was about thirteen thousand, estimates in this respect vary. Naylor and Reid have each claimed that only about ten thousand individuals were involved, while Griffiths has placed the number between twelve and seventeen thousand, tending toward the latter. See Guillemin, Urban Renegades, 52-53; Naylor, Canada in the European Age, 131; Reid, Six Crucial Decades, 44; and Griffiths, The Contexts of Acadian History, 89.

2. See MacDonald, Rebels and Royalists, 10, 28-33. MacDonald notes that the first group of New Englanders to move into Acadia "were descendants of English families who had come to America in the 1630s [and most] were Congregationalists" (33). Cf. Stewart, Documents Relating to the Great Awakening in Nova Scotia, xxi, and Moir, The Church in the British Era, 17-18.

3. Stewart, Documents, xv.

4. Bumsted, Henry Alline, 66.

5. See Rawlyk, "The 1770s," 31. Rawlyk suggests that "the Great Awakening of Nova Scotia may be viewed as an attempt by many inhabitants to appropriate a sense of identity. Religious enthusiasm in this context ... was symptomatic of a collective identity crisis." Cf. Stewart and Rawlyk, A People Highly Favoured by God, 190-192. Henry Alline was born in Rhode Island in 1748, and moved with his Puritan family to Falmouth, Nova Scotia, at the age of twelve. Cf. Bumsted, Henry Alline, 3.

6. See Stewart and Rawlyk, A People Highly Favoured by God, 166; Rawlyk, Wrapped Up in God, 16, 53; and Rawlyk, "The 1770s," 31: "God was passing New England's historical role of Christian leadership to Nova Scotia. With two powerful Protestant nations furiously battling one another, the whole course of events since the Reformation seemed to be ending in a meaningless tangle ... it could only indicate one thing, that the entire Christian world, apart from Nova Scotia, was abandoning the way of God"; and Rawlyk, "New Lights, Baptists, and Religious Awakenings," 53.

7. Rawlyk, "New Lights, Baptists, and Religious Awakenings," 48.

8. See Cogswell, "The Maritime Provinces," 71-72. New Brunswick was formed at the request of Loyalist settlers in 1784. Cf. Upton, Micmacs and Colonists, 98, and Cumming and Mickenberg, Native Rights in Canada, 103.

9. Fingard, The Anglican Design in Loyalist Nova Scotia, 43, notes, "The majority of the Loyalists arrived in the province as destitute immigrants . . . they had shared the misfortune of losing their property." She refers to the "Minutes of the Port Roseway Associates for 1782" that listed settlers by occupation, and demonstrated a large proportion of "artisans, farmers, and tradesmen" (Public Archives of Nova Scotia). Cf. MacNutt, The Making of the Maritime Provinces , 94.

10. Kline, Beyond the Land Itself, 54-59. 


\section{Gesner, New Brunswick, With Notes for Emigrants, 3.}

12. Stephen Hornsby has suggested that in respect to the Highland Scots, in particular, "Rising prices for wool and meat during the Napoleonic Wars encouraged clan chiefs to clear many of the agricultural villages ... . and to lease the land to large, progressive sheep farmers. ... Neither the destruction of the traditional agricultural economy nor its replacement by crofting and kelping [an industry that emerged as a result of a French embargo on alkali] were readily accepted. .. Fearing that they might lose land, rights, and status ... many preferred to emigrate, hoping to re-create overseas something of the life that was being destroyed in Scotland" I"Scottish Emigration and Settlement in Early Nineteenth Century Cape Breton," 49-54). Cf. Campbell and MacLean, Beyond the Atlantic Roar, 7-17.

13. Walter Johnstone's letter of October 23,1821, quoted in Harvey, Journeys to the Island of St. John or Prince Edward Island, 143.

14. Gesner, New Brunswick, 1.

15. Much of the following discussion is based upon a work by Donald Levine called The Flight from Ambiguity. In respect to the nature of pre-seventeenth-century European discourse, Levine suggests, "the language used to represent human affairs was valued for being vivid and evocative more than for its denotational precision. Metaphor, irony, and analogies of all sorts were the stock in trade" (1).

16. Levine, The Flight from Ambiguity, 2. Cf. Morrison, The Embattled Northeast, 43-44: "Greater literacy-itself the hallmark of civility-also strained social relations.... While scholars were discovering that European vernacular languages possessed an admirable vitality, the folk were condemned as quickly as they came to literate consciousness. Study of rural oral traditions led to efforts to eradicate vulgar speech."

17. From an essay written in 1690 entitled "On the Abuse of Words," quoted in Levine, 3 .

18. Cited in Bell, Defoe's Fiction, 11. Levine focusses particularly on the influence of mathematical language upon the writing and thought of Descartes, Leibniz, and Hobbes (2), and suggests that Samuel Johnson's dictionary represented an apex of this trend toward linguistic purity, as he sought to establish "univocal meanings in perpetuity" (4). Ernest Campbell Mossner points out that the "Edinburgh Circle" of the mid-eighteenthcentury that included David Hume, William Robertson, and Adam Smith called for the absolute rejection of vernacular languages. The circle had a substantial influence on the contemporary European intellectual climate. See The Forgotten Hume, 16-17.

19. Levine, The Flight from Ambiguity, 8.

20. Taylor, The Ethics of Authenticity, 102. Frye discussed the cogito ergo sum as a product of a desire "to derive human existence from human consciousness, and to see that consciousness as being in a different world from the nature which for Descartes was pure extension in space" (Divisions on a Ground, 169). We might add that, a century after Descartes, Kant's understanding of the ego was essentially an expansion on the foundation laid by the cogito ergo sum. This notion effectively separated consciousness from the empirical world. See Smith, A Commentary to Kant's Critique of Pure Reason, $211 \mathrm{ff}$. , and Mauss, Sociology and Psychology, 89.

21. Howe, Poems and Essays, 32.

22. See Condon, The Loyalist Dream for New Brunswick, 175.

23. Cogswell, "Literary Activity in the Maritime Provinces," 104.

24. Quoted in Heik, History and Myth, 300.

25. Heik, History and Myth, 301. 
26. Howe's letter is cited in Bliss, Canadian History in Documents, $68-69$

27. Tuan discusses the presence of these primordial symbols in the Bible, which begins with the chaos of Genesis and ends, for Christians, with the heavenly city of Revelation. "In the beginning," as described in Genesis, the entire earth existed in a wilderness state. "The waters represented the primordial undifferentiated flux, the chaos out of which was to emerge, first, dry land, then culture. ... On the dry land [God] 'planted a garden eastward in Eden.' God acted the role of the divine gardener" (Man and Nature, 24-26).

28. See Sparling, "The British Vision in Nova Scotia," 9. Cf. McGregor, The Wacousta Syndrome, 11. McGregor points out that there appears to have been a common tendency among early Canadian colonials to avoid "having to focus on nature . . . at all" (29).

29. For more general discussion of the negativity of wilderness in Canadian art and literature see Marcia Kline, Beyond the Land Itself. Kline points to a fundamental difference in attitude toward nature between American and Canadian writers, noting that Americans were often able to look upon nature as something very positive (though no less founded in the imagination). The "frontier" in American literature has signified a notion of the natural world as something about which human beings can feel some confidence despite any experience of terror. "No such thing was possible in Canada. The wild state was too terrifying. ... Schematically, this means that the Canadian skips the frontier and looks east-east to the landscapes of Gloucestershire and the all-protective Union Jack. But the American ... never goes East, instead he confidently 'lights out for the West' and the home of Natty Bumpo" (40-52); McGregor, The Wacousta Syndrome, 5-10; Frye, The Bush Garden, 141-142, 225. Frye admits that he has "long been impressed in Canadian poetry by a tone of deep terror in regard to nature."

30. West, A Journal of a Mission to the Indians of the British Provinces, 226.

31. Burtis, New Brunswick as A Home for Emigrants, 6.

32. Howe, Poems and Essays, 24.

33. Howe, Poems and Essays, 32.

34. Haliburton, The Old Judge, xiv, 3.

35. The term was not actually used by colonials until the late eighteenth-century, when it began to be employed as a descriptive term for certain cultural processes at work in France and England. See Long, "Primitive/Civilized: The Locus of a Problem," 49. Jennings has also noted that "civilization is rarely conceived of in terms of empirical data. .. It implies not only technical but moral superiority over the stages assumed to be lower on the evolutionary scale" (The Invasion of America, 8-10).

36. Antonio De Luca, quoted in Johnson, A History of the Catholic Church in Eastern Nova Scotia, vol. 2, 176.

37. Burtis, New Brunswick as a Home for Emigrants, 36-37. Writing in a similar vein, another nineteenth-century historian claimed, "The removal of such large bodies of the human family from one country, climate, and government, to other regions so entirely different, is one of the most remarkable social phenomena of the present century. There appears to be little reluctance, in this age, to leave one's country, the land of one's childhood, and the home of early associations. The great desideratum with the emigrant is the improvement in his social, moral, political, and pecuniary condition; an object undoubtedly highly important to the welfare of our race." See Monro, New Brunswick with a Brief Outline of Nova Scotia and Prince Edward Island, 376.

38. West, A Journal of a Mission to the Indians of the British Provinces, 216. 
39. See Cumming and Mickenberg, Native Rights in Canada, 96-97; Upton, Micmacs and Colonists, 37, Dickason, "Frontiers in Transition," 24; and Morrison, The Embattled Northeast, 166.

40. The proclamation was issued on May 4, 1762, and is filed at the Public Archives of Nova Scotia. It is also reprinted in its entirety in Gould and Semple, Our Land: The Maritimes, 177.

41. See Letter of Jonathan Belcher to the Lords of Trade, July 2,1762, quoted in Cumming and Mickenberg, 286-287. Cf. Jennings, Empire of Fortune, 185; Upton, Micmacs and Colonists, 59-60.

42. Reid, in Six Crucial Decades, notes that Lawrence's proclamation "promised land grants with no rents payable for the first ten years, government structures similar to those of the New England colonies, military protection from any possible Indian attack, and full religious freedom for all Protestants" (50).

43. See MacNutt, The Making of the Maritime Provinces, 15; Upton, Micmacs and Colonists, 116, 119-120; Titley, A Narrow Vision, 6.

44. Letter of Lieutenant-Governor Charles A. Fitzroy to Lord Glenelg, October 8, 1838, and Journals of the Legislative Assembly of Prince Edward Island, 1840, appendix N, 111-113. Cited in Upton, Micmacs and Colonists, 114.

45. See Petition of the Tabusintac Indians, September 26, 1801, MGH54, Harriet Irving Library Archives (HILA), University of New Brunswick. Cited in Upton, Micmacs and Colonists, 99.

46. Indian Agent William Chearnley to Joseph Howe, March 4, 1854. Journals of the Legislative Assembly of Nova Scotia (JLANS), 1854, appendix 26, 211-212. Cited in Whitehead, The Old Man Told Us, 252. Cf. Patterson, The Canadian Indian, 116.

47. Agreement of July 29,1807, University of New Brunswick Archives, cited in Cumming and Mickenberg, Native Rights in Canada, 103.

48. See William Chearnley's report cited in Whitehead, The Old Man Told Us. Cf. JLANS, appendix 45,1849, cited in Ralston, "Religion, Public Policy, and the Education of Micmac Indians," 187; Patterson, The Canadian Indian, 117; Upton, Micmacs and Colonists, 95, 101.

49. See William F. Odell to G. Sproule, September 16, 1808, MGH54, HLA, cited in Upton, Micmacs and Colonists, 99. Cf. Gould, Our Land: The Maritimes, 49.

50. See Bromley, An Account of the Aborigines of Nova Scotia, 10.

51. Bitterman, "Economic Stratification and Agrarian Settlement," 85.

52. Gesner, New Brunswick, 116. Cf. Upton, Micmacs and Colonists, 114; Patterson, The Canadian Indian, 117.

53. Murdoch and Rogers to Herman Merivale, October 14, 1848, Colonial Office Series (CO) Public Records Office, London 386/83, 146-153, cited in Hamilton, "Indian Lands in New Brunswick," 19. In 1859, the Nova Scotia legislature passed "An Act Concerning Indian Reserves" that required, in the words of Crown Lands Commissioner Samuel Fairbanks, that "squatters must either go or pay to remain." The bill, however, was never enforced. See Gould, Our Land: The Maritimes, 52.

54. Hamilton, "Indian Lands," 17. The article appeared in the Royal Gazette, September $25,1844$.

55. Journals of the Legislative Assembly of New Brunswick (JLANB), March 29, 1843, 235-236, cited in Upton, Micmacs and Colonists, 101.

56. Gesner, New Brunswick, 246, 383. 
57. This reference to The Nomands of the West appears in Huygue, Argimou, introduction, iv.

58. See Gesner's Reports on Indian Affairs, JLANS, 1847 and 1848, cited in Cumming and Mickenberg, Native Rights in Canada, 104, and Upton, Micmacs and Colonists, 139.

59. Huygue, Argimou, 4. The report to the Nova Scotia legislature was presented on July 13, 1801. Public Archives of Nova Scotia (PANS), MSS. Documents, vol. 430, document $721 / 2$, cited in Hutton, "Indian Affairs in Nova Scotia," 46-47.

60. West, A Journal of a Mission, 252.

61. Nova Scotian, May 7, 1840, cited in Upton, Micmacs and Colonists, 136.

62. Gesner, New Brunswick, 108.

63. Perley's Report of 1841, quoted in McGee, The Native Peoples of Atlantic Canada, 83, 89.

64. Perley's Report of 1841, cited in Hamilton and Spray, Source Materials Relating to the New Brunswick Indian, 93.

65. Hardy, Sporting Adventures in the New World, 40.

66. Jennings has suggested that this may be a common thread in a more generalized American "conquest Myth ... that the savage creatures of the wilderness, being unable to adapt to any environment other than the wild, stubbornly resisted God or fate, and thereby incurred their suicidal extermination" (The Invasion of America, 15).

67. Nova Scotian, April 6, 1846, cited in Upton, Micmacs and Colonists, 139.

68. See Upton, Micmacs and Colonists, 103.

69. ILANS, appendix 20, 2, 1854, 211 , cited in Ralston, "Religion, Public Policy, and the Education of Micmac Indians," 188. Patterson, The Canadian Indian, 118.

70. Gesner, New Brunswick, 113, 114.

71. Monro, New Brunswick, 277.

72. Perley's Report of 1841, cited in McGee, The Native Peoples of Atlantic Canada, 82-83.

73. Huygue, Argimou, 171. The book was published initially in serial form in the New Brunswick newspaper The Amaranth between May and September 1842. Huygue wrote it under the pseudonym "Eugene" (Argimou, ii).

74. Quoted in Whitehead, The Old Man Told Us, 228, and Upton, Micmacs and Colonists, 137.

75. From the Memoir of Governor John Parr, Collections 14 (Nova Scotia Historical Societyl, 1909: 51; quoted in MacKinnon, This Unfriendly Soil, 69. Parr added, "it is the most inhospitable climate that ever mortal set foot on ... and the land is covered with a cold, spongy moss."

76. From Howe's "Acadia," in Poems and Essays, 32.

77. Cowdell was a Halifax Methodist preacher who published his poetry in Dublin, Ireland, to pay for a trip to England in 1809. The poem is quoted in Chittick, Thomas Chandler Haliburton, 193.

78. West, A Journal of a Mission to the Indians of the British Provinces, 226.

79. Howe, in "The Song of the Micmac," referred to the Mi'kmaq as "Free sons of the forest." See Lochhead and Souster, 100 Poems of Nineteenth Century Canada, 2. In "The Old Hunter," a piece on the exploits of William Chearnley, Hardy referred to a 
sleeping Mi'kmaq guide as "the slumbering son of the forest." See Hardy, Forest Life in Acadia, 103, cited in Whitehead, The Old Man Told Us, 270.

80. See West, A Journal of a Mission to the Indians of the British Provinces, 229. Walter Bromley, in An Account of the Aborigines of Nova Scotia, referred to the $M i ' k m a q$ as "forlorn brethren of the woods" (5).

81. William Thomas Baird, in Seventy Years of New Brunswick Life, 113, wrote, "Within my own time and recollection I have seen some of these children of the forest exhibit an ease and freedom of manner and a nobility of character becoming to true princes of the land."

82. The Nova Scotian, April 6, 1846, quoted in Upton, Micmacs and Colonists, 138; Whitehead, The Old Man Told Us, 229.

83. Howe, Poems and Essays, 25.

84. Perley, Camp of Owls, 88.

85. Monro, New Brunswick, 276.

86. See Monkman, A Native Heritage, 9, and Cogswell, "Literary Activity in the Maritimes," 121.

87. Gesner, New Brunswick, 115. Cf. 49.

88. Howe, Poems and Essays, 32.

89. Gesner's Report on Indian Affairs for 1848, ILANS, appendix 24, 114-125, cited in Ralston, "Religion, Public Policy, and the Education of Micmac Indians," 186. Gesner's goal was to see the Mi'kmaq brought to an enjoyment of "the comforts of refined society."

90. From his Report of 1841, cited in McGee, The Native Peoples of Atlantic Canada, 83, Perley felt certain that "with the exercise of a sound discretion, and under proper and careful supervision, the Indians of New Brunswick may be gradually led to adopt Agricultural pursuits, and acquire habits of settled industry-that instructed by Masters of competent knowledge, and of strictly moral and religious character, they would readily acquire every species of useful information, and that thus ... [they] would be preserved from utter annihilation, and in progress of time become useful and respectful members of society." From his report, cited in Hamilton and Spray, Source Materials Relating to the New Brunswick Indian, 98, and McGee, The Native Peoples of Atlantic Canada, 89.

91. "The Claims and Prospects of the Micmacs," Christian Messenger, March 15, 1855, cited in Upton, Micmacs and Colonists, 168.

92. Elder, "The Aborigines of Nova Scotia," 3.

93. March 11, 1817, cited in Upton, Micmacs and Colonists, 138.

94. McGee, The Native Peoples of Atlantic Canada, 88.

95. We should note that he was speaking here of grown men. Upton, Micmacs and Colonists, 129 , and 215 , note 17 .

96. Halifax Reporter, August 11, 1860, 2, quoted in Whitehead, The Old Man Told Us, 262.

97. Gesner, New Brunswick, 250.

98. Jonathan Odell to Gervas Say, May 11, 1789, Provincial Archives of New Brunswick (PANB), Rex/Pa, Indians, I, 71, cited in Hamilton and Spray, Source Materials Relating to the New Brunswick Indian, 70. 
99. See Statutes of Nova Scotia, 1842, cited in Ralston, "Religion, Public Policy, and the Education of Micmac Indians," 183. Cf. Upton, "Indian Policy in Colonial Nova Scotia," 9 .

100. ILANS, appendix 37, 1864, in Ralston, 189.

101. See Miller, "The Decline of the Nova Scotia Micmac Population," 111; Gould and Semple, Our Land: The Maritimes, 39; Miller, Skyscrapers Hide the Heavens, 87-89; Upton, Micmacs and Colonists, 129. Miller notes that, because of the relative lack of cattle in the colonies, colonists were prone to killing moose for which New Englanders, in particular, had a taste. Upton adds that moose were also valued for their skin, and whites killed them rather indiscriminately for this reason in the early years of settlement. In 1789, for instance, estimates place the number taken from Cape Breton alone at nine thousand.

102. Dickason, "Frontiers in Transition," 28.

103. Forty Mi'kmaq families "belonging to the District of Antigonishe, Pomquet and Tracadie in the Gulf of St. Lawrence" were reported to be "in a starving condition, and almost destitute of Clothing," in 1800, JLANS, April 2, 1800, cited in Whitehead, The Old Man Told Us, 184. Cf. Miller, "The Decline of the Nova Scotia Micmac," 111; Ralston, "Religion, Public Policy, and the Education of Micmac Indians," 479.

104. PANS, RG1, vol. 430 , doc. 60 , cited in Miller, "The Decline of the Nova Scotia Micmac," 112.

105. See Upton, Micmacs and Colonists, 100.

106. Perley's Report of 1841. Cf. Whitehead, The Old Man Told Us, 223-224; McGee, The Native Peoples of Atlantic Canada, 83; Upton, Micmacs and Colonists, 128. Abraham Gesner also noted that "the sufferings of the sick and infirm surpass description, and from lack of a humble degree of accommodation, almost every case of disease proves fatal. In almost every encampment are seen the crippled, the deaf, the blind, the helpless orphans, with individuals lingering in consumption which spares neither young nor old." See Wein, Rebuilding the Economic Base of Indian Communities, 14-15.

107. See PANS, RG1, vol. 430, doc. 176 and vol. 431, doc. 9. Cited in Miller, "The Decline of the Nova Scotia Micmac," 112.

108. PANS, RG1, vol. 431, docs. 1 and 61, and RG1, vol. 431, February 18, 1855 , and March 10, 1856. Quoted in Miller, "The Decline of the Nova Scotia Micmac," 111.

109. Mi'kmaq population figures are difficult to establish, especially for the eighteenth-century. These numbers are based on Miller, "The Decline of the Nova Scotia Micmac," 114; Upton, Micmacs and Colonists, 45; Elder, "The Aborigines of Nova Scotia," 1; Johnston, A History of the Catholic Church in Eastern Nova Scotia, 109; and Wein, Rebuilding the Economic Base of Indian Communities, 14. Figures for 1847 range from 1,166 to 1,461 , and for 1871 from 1,500 to 1,666 .

110. These figures have been variously arrived at on the basis of statistics contained in Upton, Micmacs and Colonists, 32 and 45; Guillemin, Urban Renegades, 53; and MacNutt, The Making of the Maritime Provinces, 13.

111. PANS, MSS, Documents, vol. 430, doc. 149 1/2. Cf. Hutton, "Indian Affairs in Nova Scotia," 42-43.

112. During the late eighteenth and early nineteenth centuries, England had a large domestic market for wood products. Charcoal was the country's most sought-after industrial fuel, lumber was the building material of choice for houses, factories, and furniture, and the British navy constantly required masts for its ships. The American colonies supplied most of the wood required by Britain until the revolutionary war severed 
this relationship, and at this point, New Brunswick timber became a commodity of value in the British market. By 1825 , Britain was importing twice as much timber from New Brunswick than from all the other North American colonies combined. See Naylor, Canada in the European Age, 177-180.

113. Bromley, An Account of the Aborigines of Nova Scotia, 9.

114. Upton, Micmacs and Colonists, 101, 130.

115. Wein, Rebuilding the Economic Base of Indian Communities, 17.

116. Lieutenant-Governor George Dundas to the Duke of New Castle, October 15, 1860, CO. 226/92, 331-332, in Upton, Micmacs and Colonists, 119.

117. He was able, in 1860 , to shave the going price on greatcoats from three shillings to two shillings, sixpence by buying used ones. Ralston, "Religion, Public Policy, and Education of Micmac Indians," 189.

118. Perley's desire to have the $\mathrm{Mi}^{\prime} \mathbf{k m a q}$ share in the comforts of civilization was previously considered in respect to the colonial effort to eradicate a sense of cultural guilt. I might add here that he undoubtedly carried a similar personal sense of transgression since he and a friend had killed a Mi'kmaq man while target-shooting when he was nineteen. Interestingly, Perley was fined ten pounds for this offense in the early years of the nineteenth century. Another young man who was found guilty of the same crime in the latter part of the eighteenth century was executed because of an outcry from the native community. The strategic significance of the Mi'kmaq was significantly changed within the space of less than forty years. See Mitcham, Three Remarkable Maritimers, 23. For reference to the earlier shooting, see the Royal Gazette and New Brunswick Advertizer, June 27, 1786, cited in Upton, Micmacs and Colonists, 145.

119. Perley's Report of 1841. Cf. Upton, Micmacs and Colonists, 105; Hamilton and Spray, Source Materials Relating to the New Brunswick Indian, 93-97; Hamilton, "Indian Lands in New Brunswick," 15-17. The relative ease with which Perley promoted interaction between whites and the Mi'kmaq was unusual for the period. His experience as a fur trader when he was a teenager likely had some impact on this. See Mitcham, Three Remarkable Maritimers, 22.

120. Printed in the Royal Gazette, Fredericton, September 25, 1844; cited in Hamilton and Spray, Source Materials Relating to the New Brunswick Indian, 114.

121. Upton, Micmacs and Colonists, 107-110; Hamilton and Spray, Source Materials Relating to the New Brunswick Indian, 116; Titley, A Narrow Vision, 5-6. 


\title{
CHAPTER THREE
}

\section{THE SHROUDING OF AMBIGUITY}

\begin{abstract}
$\mathrm{W}$
HY is it that the British colonial language of inclusion (paternalistic and morally degrading though it was) was at such variance with colonial practice? The answer may lie in the British assertion of cultural purity that sought to create the colonial human being and Acadia itself, and that, paradoxically, constituted the foundation of calls for the civilization of aboriginal peoples. The claim to be firmly British was clearly problematic. These peoples' European identity had been transformed in the process of becoming colonials. Western Europeans, for instance, were not scalpers; the British in eighteenth century Acadia were. After announcing in 1749 that the Mi'kmaq were "Rebels of His Majesty's Government or as so many Banditte Ruffians," the Nova Scotia Council instructed all colonists to "annoy, distress, and destroy the Indians everywhere," and proceeded to place a bounty of "ten guineas" on native prisoners or their scalps. Eight months later, it was raised to fifty pounds. ${ }^{1}$
\end{abstract}

Among Acadia's colonial population, many other changes also occurred, the most obvious being the disintegration of European class structures. The British government's attempt to establish a planter colony in Prince Edward Island, by granting twenty thousand acres of land each to sixty proprietors, failed to produce the society for which they had hoped. With the option of claiming free grants of property in other British North American colonies, few immigrants had any inclination to become tenant farmers. ${ }^{2}$ The availability of land throughout the col- 
onies altered the social character of immigrants and their children in ways that were most striking to European visitors. Joseph Gubbins, a British officer stationed in New Brunswick between 1810 and 1816, reported

The value of land in this part of the world may be said to consist in the labour which the proprietor can bestow upon it ... rather than from its own intrinsic worth. The sons of the officers of rank and of other gentlemen who took refuge here after the American war... are certainly inferior to their parents in every respect that relates to manners and good society. ... There hardly exists any class of Society on this side of the Atlantic. The poor are not educated to respect the rich as in Europe. ... It is remarkable that amongst the immediate descendants of the English, little of British manners or customs are to be found. ... The habits of the people are adverse to subordination, the price of labour is ... high. ${ }^{3}$

This became a society in which for whites

of every rank and degree, the road to wealth and distinction is [free]. ... There are no favoured classes-no exclusive privileges no absurd or depressing monopolies-no checks nor hindrances to landable ambition-no station unattainable by patient industry and honest worth. With nothing to cramp his energies or chide his hopes and aspirations, the intelligent European who seeks this country for a home, may reasonably look forward to comfort, if not wealth and position. ${ }^{4}$

While the hierarchical structure of English society was becoming unfastened in Acadia, recognized sites of cultural authority were also undergoing transformation. Nova Scotia had been consciously constituted by the Crown as an Anglican colony when, in 1758, the Church of England was granted legal privilege with the financial support of the home government. In the wake of the American Revolution, a commitment to solidifying the alliance between church and state in the remaining British North American colonies was reinforced with the intention of securing the loyalty of Acadia's population. Charles Inglis thus became Britain's first colonial bishop in 1787, with a charge to administer church affairs in Nova Scotia and Prince Edward Island for the remainder of his life, and in New Brunswick, Newfoundland, and Canada until such time as another appointment was deemed necessary in those colonies. ${ }^{5}$ Church and state were to function hand in hand in British North America so that the strong sense of allegiance to England that had crumbled in the American colonies might be sustained. For the eighteenth-century English, an Anglican and British identity were necessarily contiguous, and the Church of England faithfully served the principles of order and society recognized as English. So, for instance, Charles Inglis maintained that 
a state of Society is the natural state of man; and by the constitution of his mind and frame is fitted for it ... as nature has thus made us members of Society, without any choice or will of ours; so, whatever happiness or perfection we are capable of, can only be attained in Society. ${ }^{6}$

In respect to the role of the church in society, Inglis confirmed that

Government and Religion are therefore the pillars, as it were, on which society rests, and by which it is upheld; remove these, and the fabric sinks into ruin ... there is a close connection between that duty which we owe to God, and the duty we owe to the King, and to others in authority under him. So intimate is this connection, that they can scarcely be separated. Whoever is sincerely religious towards God, from principle and conscience, will also, from principle and conscience, be loyal to his earthly Sovereign, obedient to the laws, and faithful to the government which God hath placed over him. ${ }^{7}$

Acadian colonials by and large did not share this understanding of their identity. They came, rather, to regard themselves in a very different manner, as people who were ineradicably British while remaining markedly autonomous of the Church of England. Despite the fact that the church was legally established in the colonies, it ultimately represented only a minority of the population. In Nova Scotia, for example, this amounted to about twenty percent of the population in 1816, and about twenty-eight percent of all Protestants in $1827 .^{\circ}$ Overwhelmingly, the Anglican Church became identified with the colonies' political elites during this period. ${ }^{9}$ This had been the case in New Brunswick from the colony's inception, ${ }^{10}$ and had been graphically affirmed in Nova Scotia after 1808, when the bishop was granted a seat on the legislative council. ${ }^{11}$ Aside from this elite class, the general British population had little difficulty imagining themselves as British without an identification with the authority of the Church of England. As an Anglican clergyman noted in 1812, "I do not think the people of this colony are as religious as they are loyal. I think there is much more loyalty than religion among us."12

A related shift occurred in the period that signified an equally, if not more, profound re-interpretation of what constituted ultimate authority in the colonial Acadian's life. To the dismay of the Anglican clergy, a proliferation of dissenting churches occurred from the late eighteenth century onward. Adherents of dissenting Protestantism were disparaged as "enthusiasts" by their Anglican critics who regarded the dissenter as

one who vainly and without grounds, believes that he has such revelations, calls or commission [from the Deity]. In general this 
proceeds from a heated or disordered imagination; the suggestions of which are mistaken for luminous communications from God.13

The enthusiasts were also perceived as posing a threat to the social order:

Swarms of teachers who are ignorant, low \& fanatical to a degree that is scarcely credible, infest every district. . . Their wild notions are imbibed, which militate against Order both in Church \& State. The minds of people are hereby perverted \& prejudiced against our excellent Church. ${ }^{14}$

In spite of these dire predictions of social ruin, colonial society did not fall victim to the rejection of the Church of England in Acadia, though another locus of authority was rather critically redefined in the process of rejection-that of the colonial relationship to God.

The New England colonies were the initial source of immigration in the region, and these settlers were by and large associated with dissenting churches. The majority of New Brunswick's early immigrants, for instance, were Congregationalists descended from the English who had arrived in New England in the 1630s. ${ }^{15}$ Most who arrived in the two decades prior to the revolutionary war came from areas that had participated in the Great Awakening of the 1740s, and they tended to be evangelical Congregationalists ${ }^{16}$ who espoused a firm Puritan morality. It has been noted that with this population

religion was a stern affair, the Puritanism of New England but little softened in passing into Nova Scotia. Dancing and card-playing were condemned, and Sabbath observance was strictly enforced. Heads of families who did not attend church were fined. ${ }^{17}$

These Yankees initially identified strongly with their New England roots. A Congregational meeting house built in Halifax in 1749, for example, was known as "Mather's," in honour of Cotton Mather and the immigrants' Boston heritage. ${ }^{18}$

Throughout the numerous revivals that characterized the period between the 1770s and the 1810s, links with New England's Puritans remained overt. During the initial revival brought about substantially by the preaching of Henry Alline and his contemporary William Black, many older members of the settler population recognized the recurrence of a phenomenon through which they had lived in the New England Great Awakening forty years earlier. Following a sermon that Alline preached in February of 1783, one of these older settlers recorded in his diary, "This is a wonderful day and evening. Never did I behold 
such an appearance of the Spirit of God moving upon the people since the time of the Great Religious Stir in New England many years ago." 19 The churches instituted during this first Nova Scotia awakening were not structurally distinct from their New England forerunners, ${ }^{20}$ and even the sense of charge underlying the identity Alline offered his contemporaries-to become "the salt of the earth, the light of the world, and as CITIES ON HILLS" 21 - was essentially an extension of the Puritan mission articulated by John Winthrop one hundred and fifty years earlier: "For wee must Consider that wee shall be as a Citty uppon a Hill, the eies of all people are uppon us." ${ }^{22}$ Likewise, Nova Scotia's second Great Awakening of 1790-1812 was not an isolated event, but was influenced by a wider contemporary movement sweeping through New England and beyond during the period, and the preachers involved in this revival travelled circuits that were relatively oblivious to the international border. ${ }^{23}$

There was an obvious continuity between the Acadian and New England traditions. Yet, the particular foundations laid by the work of Alline and Black influenced the Protestant profile of the region throughout the colonial period, and these signified a shift in both the language and experience of God within the Acadian British community. Both the New Light churches that emerged from Alline's revival and the evangelical Methodism launched by Black contributed to the development of Maritime Baptist and Methodist churches, ${ }^{24}$ and influenced the Protestant profile of Acadia for a century after their deaths. ${ }^{25}$ As late as 1858, a Presbyterian churchman still asserted that Henry Alline "did more good by his labours than any minister that ever lived in Nova Scotia." 26 This legacy was constructed on a theology that not only assailed the authority of Anglican ritual but the Calvinist substratum of the Puritan vision of God.

New England's Puritans, according to Richard Slotkin, envisioned God as one "whose authority was absolute and arbitrary," and the human being as "utterly depraved and dependent; but through the infusion of divine grace, God might purify man, make him a visible saint. ${ }^{\prime 27}$ Thus every human being was irrecoverably bound by the will of God to an eternity of either salvation or condemnation. ${ }^{28}$ Alline and Black each assailed this fundamental notion of predestination. In his hymn, "Free Grace," Alline told the faithful,

Awake O Guilty World Awake

Behold the Earths foundation shake

While the Redeemer bleeds for you

His Death proclaims to all your race

Free Grace, Free Grace, Free Grace, Free Grace

Too all the Jews and Gentiles too. ${ }^{29}$ 


\section{Black likewise claimed,}

It is affirmed, that "man has nothing at all to do; that if he lift a hand towards his own salvation, he will be damned." But is not this contrary to the words of St. Paul, - "Work out your own salvation, with fear and trembling." If indeed by "towards salvation," they meant, towards purchasing it, they would affirm nothing but the truth; but if they refer to our obtaining salvation, the assertion is utterly false. For though Christ has died for us, he has neither repented nor believed for us; still, therefore, if we repent not, we shall perish-if we believe not, we shall be damned. The Scriptures urge us to turn, seek, knock, strive, wrestle, run, \&c. And is this, I Would ask, doing nothing? absolutely nothing? Is it not for salvation that we are to seek, ask wrestle and run? Does the sinner repent that he may perish, or believe that he may be damned? or rather does he not do both in order to gain salvation? $?^{30}$

The revival movements and churches spawned by these preachers were founded in theologies in which salvation became the choice of the human being, not God. And not only was the onus for salvation placed upon the human, but in some sectors the experience of God itself came to be recognized as humanly generated. Stewart and Rawlyk have suggested that nineteenth-century Baptist preachers, for instance, increasingly regarded the revivals they oversaw as events that they had "willed" into being. ${ }^{31}$ For these colonials, the authority of the Church of England was no longer a necessary condition of a British identity. The "absolute and arbitrary" authority of the Calvinist God was an equally needless postulate for being a dissenting Protestant.

Changes in warfare, social distinctions, church structures, and theology all pointed to the fact that the Acadian British were clearly part of a world that was not England. Over time, it also became a world whose problems the British government did not perceive as its own, so that by 1842, when a group of representatives of the $\mathrm{Mi}^{\prime} \mathrm{kmaq}$ of New Brunswick arrived in London to personally present the Queen with a petition, they were politely asked to go home. The colonial officer told them,

Her Majesty has not been able to grant you an interview, but Her Majesty has signified Her Pleasure that you should each be presented with a Medal in token of the Interest which Her Majesty takes in your welfare. I am further desired to acquaint you that a Dispatch has been addressed to the Governor of Canada recommending you to his protection; and that in future any application which you may have to prefer should be made to that officer, or the Lieutenant-Governor of New Brunswick, by whom your claims will, if necessary, be communicated to the Sct. of State.

The colonial government was subsequently directed to make certain that its problems with the native community did not, in future, cross the Atlantic. ${ }^{32}$ 
Although the colonials spoke of their unbending British identity, in reality they had become very different from Europeans. Yet the need for continuity nourished their denial of a change, and substantial effort was expended upon demonstrating the continuity that they sought. Books were written that extolled the merits of the colonies in order to convince Englishmen of the colonials' thoroughly British identity. Abraham Gesner, for instance, wrote in the opening pages of $\mathrm{New}$ Brunswick, With Notes for Emigrants, "The colony is one of great importance, with regard both to its intrinsic value and the stedfast loyalty of its inhabitants; and to place it in its true light before the British public, will be the chief object of the following pages"; and Thomas Chandler Haliburton's An Historical and Statistical Account of Nova Scotia was written to counter what he regarded as popular English conceptions that pointed to the fact that "this valuable and important Colony was not merely wholly unknown, but misunderstood and misrepresented. Every book of geography, every Gazetteer and elementary work that mentioned it, spoke of it in terms of contempt or condemnation." ${ }^{\prime 33}$

In day-to-day colonial life, the British strove to keep the potentially ambiguous $\mathrm{Mi}^{\prime} \mathrm{kmaq}$ apart from themselves and the Europeanstyled society they were creating. They denied the existence of a relationship between the white and native communities, and from earliest contact avoided situations that contained the possibility of mutuality. When the British government created the colony of Halifax in $1749,^{34}$ local native peoples immediately promised "friendship and assistance" to the colonists, and proceeded during the first winter to supply the newcomers with fish and seafood. ${ }^{35}$ Despite the fact that they initially made no hostile overtures toward the British immigrants, Governor Edward Cornwallis had a thirty-foot strip cleared and fenced around the settlement; in anticipation of native violence, he built a fort and announced, "if the Indians do begin [hostilities] we ought never to make peace with them ... [but] root them out entirely. ${ }^{\prime 36}$ We might note that Cornwallis's stratagem for dealing with the aboriginal population appeared to constitute a form of denial of the possibility of community that harkened to an English model for colonization first set out by George Peckham in the late sixteenth century. In A True Report, of the Late discoveries . . of Newfound Landes, Peckham had cautioned prospective colonizers, suggesting

if after these good and faire meanes used, the savages nevertheless will not be herewithall satisfied, but barbarously wyll go about to practice violence either in repelling the Christians from theyr Portes and safe Landinges or in withstanding them afterwards to enjoye the rights for which both painfully and lawfully they have adventured themselves thether; Then in such a case I holde it no 
breache of equitye for the Christians to defend themselves, to pursue revenge with force, and to doo whatsoever is necessary for attayning of theyr safety. ${ }^{37}$

It was perhaps within the language of treaties that the eighteenthcentury British most blatantly articulated their aversion to mutuality. As already noted, no reference to the $\mathrm{Mi}^{\prime} \mathrm{kmaq}$ had been made in the Treaty of Utrecht, so that from the outset of the British colonial period, the aboriginal population was presumed to be a non-entity. Of course, in reality, it was not so, and for the British to exploit the resources of Acadia or to colonize, the presence of aboriginal peoples had to be reckoned with in some way. The diplomacy employed in earlier FrenchMi'kmaq relations was not considered an option by Englishmen who had acquired the territory under the impression that indigenous peoples would somehow melt into the landscape; so they entered, somewhat reluctantly, into a process of treaty negotiation that aspired to effectively alienate the native population from the white community by removing the $\mathrm{Mi}^{\prime} \mathrm{kmaq}$ from land that appeared to have potential for settlement. ${ }^{38}$ Treaties, which were negotiated only in times of political or military crisis, ${ }^{39}$ had an air of finality about them, as they created boundaries that were intended to keep native peoples from further interaction with whites and their governments, and it came as a surprise to British colonials when the process did not transpire as neatly as anticipated. In a letter to the governor of Nova Scotia in 1760, an apparently exasperated Colonel Frye at Fort Cumberland wrote,

On the 30th of January last, Mr. Manack, a French Priest who has had the charge of the people at Miramichi, Richibucto, and Bucktouche, and a number of the principal men in those places, arrived here. ... With the French Priest came two Indian Chiefs, Paul Lawrence and Augustine Michael. . . . I have received their submissions, for themselves and for their tribe, to his Britannic Majesty, and sent them to Halifax for the terms by Governor Lawrence. I have likewise received the submission of two other Chiefs, who I dealt with as before mentioned, and was in hopes I had no more treaties to make with savages; but he told me I was mistaken, for there would be a great many more upon the same business, as soon as their spring hunting was over; and upon my inquiring how many, he gave a list of fourteen Chiefs ... most of which he said would come. I was surprised to hear of such a number of Indian Chiefs in this part of America ... and that they were all of one nation. ${ }^{40}$

These treaties were not "'negotiated" in the sense that they involved firm long-term contributions from both interested parties. The Treaty of Boston, for instance, was signed by the British, Abenaki, Malecite, and $\mathrm{Mi}^{\prime} \mathrm{kmaq}$ in $1725,{ }^{41}$ and was resurrected sporadically for half a century; yet, even while the St. John River Mi'kmaq were ratify- 
ing the agreement in 1749 , in Halifax Cornwallis was suggesting to the home government that any native resistance to British settlement should be met with a policy of extermination. ${ }^{42}$ The practice of treaty negotiation was ultimately abandoned by the late $1780 \mathrm{~s}$, when the colonial population was of sufficient magnitude to withstand $\mathrm{Mi}^{\prime} \mathrm{kmaq}$ resistance against appropriation. Essentially, from this point onward, the colonial population base proved capable of repelling the native community with far more efficiency than could the structure of treaties.

The possibility of mutuality was assaulted in other arenas as well. Beginning in 1713 and lasting for sixty years, the British government offered bonuses for any colonial who married a native man or woman. In 1719, for instance, Governor Richard Philips of Nova Scotia received instructions from the British government saying,

And as a further mark of His Majesty's good will to the said Indian Nations, you shall give all possible encouragement to intermarriages between His Majesty's British subjects and them for which purpose you are to declare in His Majesty's name, that His Majesty will bestow on every white man being one of His Subjects, who shall marry an Indian woman, native and inhabitant of Nova Scotia, a free gift of the sum of 10 pounds sterling; and 50 acres of land, free of quit rent for the space of twenty years, and the like on any white woman being His Majesty's subject who shall marry an Indian man, native and inhabitant of Nova Scotia, as aforesaid. ${ }^{43}$

Not one of these bonuses was ever claimed, ${ }^{44}$ and, in fact, the notion of white-Mi'kmaq marriage revolted colonials well through the nineteenth century. In a retrospective discussion of French-Mi'kmaq unions of this sort in early Acadia, Gesner scathingly noted that the French "adopted their mode of living, and even some of their barbarous customs. Their Government offered rewards to any who would marry a native, until the two races were so blended together that they could not be separated." 45

The structure of gift exchange also acquired meanings with the British that undermined human relationships rather than solidified them. ${ }^{46}$ For the colonials, gifts became interchangeable with various forms of violence, including threats, hostage taking, and war. In 1793, Nova Scotia's lieutenant-governor wrote to his Superintendent of Indian Affairs, ordering him to mount an investigation into reports of Mi'kmaq-white tension around Windsor. The letter began by ordering that "troublesome" Mi'kmaq were to be taken hostage and held in nearby Fort Edward, but the instructions were subsequently altered within the same dispatch and-in consideration of a current fear of French invasion in which the $\mathrm{Mi}^{\prime} \mathrm{kmaq}$ might become allies of the French-Lieutenant-Governor Wentworth suggested that gifts and 
food be distributed among the disaffected native population in order "that the peace of our scattered inhabitants may not be disturbed by them, and also that they will join us in case of an invasion. ${ }^{\prime 47} \mathrm{~A}$ few years earlier, Lieutenant-Governor Carleton was advised that he might "at a cheaper rate secure their friendship, than repel their hostilities ... [and] presents should be more considerable, before any new concessions of land, so that they may be entirely satisfied with the transaction. ${ }^{\prime 48}$ For the British, giving gifts to the Mi'kmaq was a means of controlling them in order to keep them at a distance from whites. In 1752, for instance, the Nova Scotia Council renegotiated the Treaty of 1725 with representatives of the $\mathrm{Mi}^{\prime} \mathrm{kmaq}$ at Shubenacadie. The Council promised to keep settlers away from reserved $\mathrm{Mi}^{\prime} \mathrm{kmaq}$ hunting grounds and to give gifts to the community on the condition that colonials were permitted to go about their business of settling without resistance from the local native population. ${ }^{49}$

Antipathy toward a relationship between the native and white communities contributed to an inability to realistically perceive native peoples. For the majority of colonials, the Mi'kmaq failed to exist as autonomous beings apart from the British imagination. Consequently, they were frequently depicted in contradictory terms, as well as in terms that obscured their distinctiveness from other colonized peoples the world over. In Acadia-to use a phrase suggested by Eleanor Leacock-the $\mathrm{Mi}^{\prime} \mathrm{kmaq}$ were contained by whites in a structure of images that rendered them "a jumble of opposites. ${ }^{\text {" }}$ "In the late eighteenth century, they were described by one writer as having copper-coloured skin, black hair, and black eyes, as well as being stout. In the next century, writers often saw people with similar physical attributes-copper-coloured skin and black hair, though sometimes with dark brown rather than black eyes. ${ }^{51}$ Yet, during the same period, other writers saw very different people. Moses Perley, for instance, described the Mi'kmaq community at Restigouche as one in which blue eyes and brown hair were increasingly common, as were individuals with skin so pale they could pass as white. ${ }^{52}$ We might wonder at the various shades of glasses these men wore as they peered out at Acadia's native peoples.

Many other contradictory images abounded throughout the period. From the 1840 s onward, commissioners presented colonial legislatures with ambivalent assessments of the state of $\mathrm{Mi}^{\prime} \mathrm{kmaq}$ "civilization." At times they assured their colleagues that progress was slow but that it was certainly occurring, and at other times they reported that native peoples were absolutely resistant and that very little "civilization" had been achieved. ${ }^{53}$ Perley reported in 1841 that "the Indians have already by their own unaided exertions, and their constant inter- 
course with the whites, made very considerable advances in civilization," while in 1861, Chearnley informed his colleagues that the Mi'kmaq "seem destined to live a roving life, almost wholly dependent on charity." ${ }^{54}$ Writers also contradicted one another in their analyses of what they perceived to be problems in the native community. Huygue bemoaned the fact that native men had become drunks as a result of a lack of strong guidance and education from the white population, and the Acadian Recorder grumbled over the fact that each summer "small groups of Indian men and woman, in various stages of intoxication, bearing unfortunate squalid infants, and followed by half-starved dogs, were continually to be met in our streets." Yet, during the same period, Haliburton defended the Mi'kmaq, saying white Cape Bretoners (with the exception of two communities/ were more given to bouts of intoxication than their native contemporaries. ${ }^{55}$ Even within single works, writers often engaged in such contradiction, as in the case of a promotional book, Advice to Emigrants, that described Acadia's aboriginal peoples as friendly, trustworthy, selfish, and dishonest. ${ }^{56}$ Gesner described them similarly, suggesting that "in all their negotiations there is little sincerity," and yet, "they are now a harmless people and ... an honest people. ${ }^{\prime 57} \mathrm{He}$ also believed they were a people with an "unalienable right" to the land that providence had permitted whites to appropriate for the progress of humanity. ${ }^{58}$ The inability to perceive the $\mathrm{Mi}^{\prime} \mathrm{kmaq}$ as coherent historical agents was perhaps most sharply illustrated by various references to the native community that blurred its distinction from other communities of the colonized. In the eighteenth century, the Mi'kmaq were said to share common physical features with "every Indian in North America. ${ }^{159}$ In the 1840s, and within the context of considering how the native population might be sufficiently assimilated, so as to bring "all distinctions between the different races [to] an end," Moses Perley noted,

A recent writer on India maintains, that instruction in the arts is far more likely to effect the intellectual improvement of an uncivilized people, than scholastic education; and he says that it is an aphorism "that an improved plow is an excellent missionary, and a chest of Carpenter's tools worth a dozen School masters, " because the value of education ... cannot be appreciated by the uneducated unless its connexion with material improvement be distinctly shewn. He says that a perception of the vast benefits of knowledge in a material point of view ... would in the natural course of things, introduce a higher order of civilization, and promote the cultivation of knowledge for its own sake. ${ }^{60}$

A letter published in the Christian Messenger in 1850 represented $\mathrm{Mi}^{\prime} \mathrm{kmaq}$ spoken English of the period as a form of near gibberish that sounded strikingly similar to contemporary depictions of other colo- 
nized peoples: "No neber see me one man, all same like dat man."61 For these men, it was obvious that the $\mathrm{Mi}^{\prime} \mathrm{kmaq}$ were not fundamentally distinguishable from other non-Europeans. "Uncivilized" peoples appear to have been uncivilized peoples-in appearance, language, and inclination-and their distinctiveness overwhelmingly lay in the counter-image they provided in respect to the British identity.

Despite the many voices that called for the entry of the Mi'kmaq into civilization, the drive toward a purity of identity negated the possibility. The indigenous population remained arrested at the peripheries of a re-created Acadia, and they were both experienced and perceived by whites as shadows. Like many humans who are relegated to the margins of social patterning, they were at times feared and at times endowed with magical qualities. ${ }^{62}$ In "The Song of the Micmac," Joseph Howe asked (in the present tensel,

Who can follow the Moose, or the wild Cariboo,

With a footstep as light and unwearied as he?

Who can bring down the Loon with an arrow so true,

Or paddle his bark o'er as stormy a sea?

And if the wild war whoop ascends on the gale,

Who can with the Micmac the Tomahawk wield?

Oh! when was he known in the combat to quail?

Whoe'er saw him fly from the red battle field? ${ }^{63}$

The Guardian echoed Howe's fear of the Mi'kmaq when, in 1839, it reported that,

The spirit of revenge is still smothering in their bosoms and although they make their canoes, and their snowshoes, and their baskets ... and are indebted to the inhabitants in whose neighbourhood they live for the sale of them it is only the lack of opportunity, or the settled conviction that their hostility in unavailing, which prevents that spirit from breaking forth in all the fury of its wonted cruelty. ${ }^{64}$

Writers also suggested that the $\mathrm{Mi}^{\prime}$ kmaq were possessed of uncanny facilities, such as the ability to "travel seventy miles in a day without any apparent fatigue," with feats such as this "often performed under heavy burdens, and without any kind of food." It was also said that "the acuteness of the Indian is almost supernatural; he can follow an animal by indications imperceptible to even an American backwoodsman." ${ }^{165}$ Campbell Hardy referred to this greater than human capacity for negotiating the wilderness in his Sporting Adventures, when he declared,

In creeping on moose, too, the Indian displays a thorough knowledge of the method of working the "yard," which is incomprehen- 
sible to the white man.... The powers of woodcraft in all its branches appear, in the Indian, to amount to an instinct not belonging to, and never capable of being attained by, the white man. ${ }^{66}$

Although the British largely avoided interaction with these peripheral figures, in one critical respect they accepted the $\mathrm{Mi}^{\prime} \mathrm{kmaq}-$ indeed, welcomed their presence. There was a place in colonial society for the entertainment value that native culture provided by virtue of its marginal status -its "otherness" - since the fact of its marginality served to affirm British purity. There was a European tradition that incorporated the figure of the wild man into English pageantry (popular particularly in the sixteenth centuryl and it provides a useful context for considering the role ascribed to the $\mathrm{Mi}^{\prime} \mathrm{kmaq}$ in nineteenth-century Acadian public celebrations. In Europe, the wild man was historically absorbed within the notion of wilderness, and he was incorporated into public shows and royal entertainments in England as a figure representing the forces of nature controlled by the Crown. He was placed in relief, as it were, to the power of the monarch; and he appeared dressed variously in animal skins, oak leaves, or ivy. ${ }^{67}$

Despite the fact that British colonials generally evaded contact with the Mi'kmaq of Acadia, they put substantial effort into securing a native presence in their parades. In anticipation of the arrival of the Prince of Wales in Halifax in 1860, the following appeal was placed in the Halifax Recorder:

The Committee for procuring Subscription and managing the affairs of the Indians in the Reception of the Prince of Wales, beg to solicit the contributions of Nova Scotians. The Indians are entirely destitute of suitable National Costume, and without the means to purchase material to make it. ${ }^{68}$

Interestingly, the "national costume" of the $\mathrm{Mi}^{\prime} \mathrm{kmaq}$ during the period was often enhanced a little, as when Chief Louis-Benjamin Peminuit Paul and his wife were placed "in a gentleman's carriage, decked with evergreens," at the Halifax celebration of Queen Victoria's wedding. ${ }^{69}$ The image of the green-decked carriage is more than faintly reminiscent of the wild man of sixteenth-century English pageantry.

In literature, too, the "otherness" of the Mi'kmaq came to play a role in the nineteenth-century. They were, on occasion, created as "exotic set pieces" within narratives. In Mary Eliza Herbert's 1859 novel, Belinda Dalton, for instance, the portrait of a nineteenth-century wedding was brought into sharp relief by the author's insertion of a graphic account of the massacre of New England settlers by eighteenth century "savages." As Leslie Monkman has pointed out, the massacre had no relationship to the story itself, and appeared as no 
more than a "sensational digression. ${ }^{70}$ Native characters were also at times fabricated as instruments of self-criticism. Huygue's Argimou, for instance, employed $\mathrm{Mi}^{\prime} \mathrm{kmaq}$ characters to criticize colonial society, drawing on a tradition of primitivism that had been popular in seventeenth- and eighteenth-century Europe. European primitivism had concerned itself with the possibility of perfecting society, and native American cultures had been imaginatively explored for models on which a happier human community might be constructed. The actual character of these cultures mattered little, as they were imagined to be peopled with beautiful and virtuous "noble savages." 71 The triumph of primitivist modes of critique was perhaps in their successful crossing of the Atlantic, and their re-emergence as American literary forms in a context that contained actual aboriginal peoples whose viability was undermined by colonial interests. ${ }^{72}$ In Argimou, Huygue assumed the inevitability of the cultural destruction of the Mi'kmaq. Nonetheless, he extolled their precontact culture as virtuous and simplistic-qualities that contact with Europeans had eroded:

I love the Indian. Ere the white-man came

And taught him vice, and infamy, and shame,

His soul was noble. In the sun he saw

His God, and worshipped him with trembling awe,

Though rude his life, his bosom never beat

With polished vices, or with dark deceit. ${ }^{73}$

Although Huygue ultimately asserted that the British and the noble Mi'kmaq were absolutely incompatible at the level of society, he also believed that on a personal level Europeans could learn something about simplicity from interaction with native peoples. ${ }^{74}$ That it took until the nineteenth century for an Acadian writer like Huygue to adopt the primitivist mode of critique popular in Europe a century earlier might be explained from two perspectives. First, in their quest for identification with English culture, nineteenth-century British colonial writers tended to adopt outdated European literary forms; ${ }^{75}$ but second, and perhaps more importantly, Huygue's Argimou reflected the assurance with which he and his contemporaries regarded the gulf between colonial society and the Mi'kmaq.

Yi-Fu Tuan has argued that in Western culture, wilderness has generally been the object of a certain level of ambivalence. Although the reaction to wilderness has been primarily negative, it has often been viewed quite sentimentally when it has become less threatening, and when those peering out at it have considered themselves safely within the protection of civilization. ${ }^{76}$ Since Acadia's Mi'kmaq were regarded as part of the wilderness, it is likely that the tendency to become somewhat sentimental over them and their culture at a moment 
in time when the native population was approaching extinction was a product also of this sort of attitude toward landscape.

In the attempt to sustain a sense of continuity of place, British colonials imagined-and endeavoured to create-Acadia in the image of the Old World. Those human beings who inhabited the real Acadia were displaced to the peripheries of the colonial re-creation, for as Tuan has noted, "purity ... requires protection. Fences must be built and guards hired to keep the sacred places pure. ${ }^{\prime 77}$ The Mi'kmaq remained far from view save for when the colonials sought to relieve a nebulous sense of transgression or when they wished to remind themselves of their European identity. The boundaries they constructed between the two communities were highly effective in allowing the British to believe they and their society were culturally pure.

When a delegation of chiefs arrived in Halifax in 1849 , the local press afforded some attention to these men whose parents and grandparents had been interacting with those of the British for a century and a half. They were described as "novel and interesting."

One might think they were speaking of strangers.

\section{Notes}

1. PANS, RG1, vol. 209, October 1, 1749; Miller, "The Decline of the Nova Scotia Micmac," 109-110; Reid, Six Crucial Decades, 37; Guillemin, Urban Renegades, 52. How many bounties were claimed remains somewhat uncertain. Miller says there was only one instance of such a claim, but records of the Nova Scotia Council show that on April 15, 1753, John Conner and James Grace arrived in Halifax harbour with six scalps between them. See Haliburton, An Historical and Statistical Account of Nova Scotia, 154.

2. MacNutt, The Making of the Maritime Provinces, 15. MacNutt notes that the granting of the island to absentee proprietors had been an experimental measure on the part of the British government, aimed at staving off potential difficulties similar to those that were occurring in the increasingly rebellious American colonies. The presence of a "landed aristocracy" was considered to be a possible safeguard in this context.

3. See Temperley, "Frontierism, Capital, and the American Loyalists in Canada," 6-9.

4. Burtis, New Brunswick as A Home for Emigrants, 30. Monro, New Brunswick, 377 , noted: "Here every man possesses a high degree of independence; so much so that, especially among the native born, all aim at being masters; few are willing to remain servants, and none think of continuing in that capacity for more than one or two years."

5. See Fingard, The Anglican Design in Loyalist Nova Scotia, 1-2, and Cuthbertson, The First Bishop, 91-92.

6. MacDonald, "The Sermons of Charles Inglis," 27.

7. Inglis, Steadfastness in Religion and Loyalty Recommended, 6, 28, cited in Fingard, The Anglican Design, 29-30. 
197.

8. Fingard, The Anglican Design, 114, 1974, and Cuthbertson, The First Bishop,

9. Fingard, The Anglican Design, 121.

10. Condon, The Loyalist Dream, 184.

11. Fingard, The Anglican Design, 121.

12. From the Halifax Journal, March 25, 1812, cited in Fingard, The Anglican Design, 121.

13. Charles Inglis, A Charge delivered to the Clergy of Nova-Scotia, at the Triennial Visitation holden in the Town of Halifax, in the Month of June 1791 (Halifax, 1792), cited in Rawlyk, New Light Letters and Songs, 305. Cf. MacDonald, "The Sermons of Charles Inglis," 31-32.

14. From a letter written by Inglis, November 26, 1811, cited in Fingard, The Anglican Design, 31 .

15. See MacDonald, Rebels and Royalists, 33, and Moir, The Church in the British Era, 17-18.

16. See Stewart, Documents Relating to the Great Awakening in Nova Scotia, xxi, and Cogswell, "The Maritime Provinces," 73. Era, 18.

17. Campbell, The History of Nova Scotia. Cf. Moir, The Church in the British

18. Akins, History of Halifax City, 21-22.

19. Harvey, The Diary of Simeon Perkins, 177, cited in Stewart, Documents Relating to the Great Awakening in Nova Scotia, xi, and Bumsted, Henry Alline, 66.

20. Bumsted, Henry Alline, 68.

21. From Alline's Two Mites on Some of the Most Important and much disputed Points of Divinity, quoted in Stewart and Rawlyk, A People Highly Favoured by God, 166. Cf. Rawlyk, Wrapped Up in God, 16, 53.

22. Miller, "Jonathan Edwards and the Great Awakening," 390.

23. Stewart and Rawlyk, A People Highly Favoured by God, 56-61.

24. See Fingard, The Anglican Design, 119. Scoby and Grant have suggested that the Free Baptists of Western Nova Scotia (also known as the Methodist Baptists) were substantially influenced by the "Allinite tradition." See Scoby and Grant, The Contribution of Methodism to Atlantic Canada, 39. Stewart and Rawlyk discern a linear development between the New Light movement and white Baptist churches in the Maritimes. See Stewart and Rawlyk, A People Highly Favoured by God, 55.

25. Rawlyk, "New Lights, Baptists, and Religious Awakenings," 48.

26. From "Henry Alline," in Christian Instructor and Missionary Register of the Presbyterian Church of Nova Scotia, March, 1859, 74, quoted in Rawlyk, New Light Letters and Songs, 25.

27. Slotkin, Regeneration through Violence, 37-38.

28. Cogswell, "The Maritime Provinces," 73.

29. Henry Alline, Hymns and Spiritual Songs (Boston, 1786), 115, cited in Rawlyk, New Light Letters and Songs, 190.

30. Richey, A Memoir of the Late Rev. William Black (Halifax, 1839), 160, cited in Rawlyk, New Light Letters and Songs, 190.

31. Stewart and Rawlyk, A People Highly Favoured by God, 68. 
32. Colonial Officer A. Blackwood to Chief Joseph Ithobeitch, François le Bobe, and Pierre Basquet, February 1, 1842; PRO CO 188/80, 446-447. Cited in Hamilton and Spray, Source Materials Relating to the New Brunswick Indian, 111.

33. Gesner, New Brunswick, 7, and Windsor, "Historical Writing in Canada to $1920, " 209$.

34. This was the first permanent British settlement in Acadia, as well as the first colony that Britain established as part of public policy. See MacNutt, The Making of the Maritime Provinces, 7; MacNutt, The Atlantic Provinces, 53-54; Upton, Micmacs and Colonists, 47, Naylor, Canada in the European Age, 137.

35. Thomas Akins, in History of Halifax City, noted that an unnamed British periodical referred in October of 1749 to a Halifax settler's report, "We have received the like promise of friendship and assistance from the Indians" (12). In his History of Nova Scotia or Acadie, Beamish Murdoch referred to a letter written by one of the early Halifax settlers in which he informed relatives in England that "when we first came here, the Indians, in a friendly manner, brought us lobsters and other fish in plenty, being satisfied for them by a bit of bread and some meat" (vol. 2, 185). Cf. Miller, "The Decline of the Nova Scotia Micmac," 109.

36. PANS, RG1, vol. 209, September 11, 1749, quoted in Miller, "The Decline of the Nova Scotia Micmac," 109.

37. George Peckham had been present on Humphrey Gilbert's 1583 voyage to Newfoundland. See Quinn, "The Voyages and Colonizing Enterprises of Sir Humphrey Gilbert," 453, and Nash, Red, White and Black, 42.

38. Upton, Micmacs and Colonists, 37.

39. Cumming and Mickenberg, Native Rights in Canada, 95.

40. Colonel Frye, to His Excellency the Governor, March 7, 1760, cited in Fisher, The First History of New Brunswick, 113-114.

41. See Upton, Micmacs and Colonists, 42.

42. Hamilton and Spray, Source Materials Relating to the New Brunswick Indian, 23; Murdoch, History of Nova Scotia, vol. 2, 169.

43. See Kaplan, "Historical Efforts to Encourage Indian-White Intermarriage," 128.

44. Ibid.

45. Gesner, New Brunswick, 113. The ease with which the early French and Mi'kmaq married or entered into amorous affairs with one another is considered in chapter four. We might note here, however, that under Louis XIV, French settlers were encouraged to "dispose them [native Americans] to come and settle them in community with the French," and to take native American spouses "in order that ... they may form only one people and one blood." See Nash, Red, White and Black, 105. The French Minister of Marine, in 1713, suggested, "The French and Indians of Acadia must look up to the Sun and the Stars from the same land; they must stand shoulder to shoulder on the battlefield ... live together in peace and harmony; and when the time comes, sleep side by side beneath the same sod of their common country." Minister of Marine to Baron de St. Castin, April 8, 1713, MGI, series 2, B series, transcripts, 35:3, 188-189, PAC, cited in Upton, Micmacs and Colonists, 32.

46. Joel Martin's discussion of gifts in respect to the relationship between the United States government and the nineteenth-century Muskogee community is useful for comparison. Martin argues that white America "was determined to force on the Muskogees an ideology that not only repressed the logic of gifts and the egalitarian society 
that it nurtured but also asserted that the Muskogees could become 'civilized' only by becoming identical to Anglo-Americans" (Sacred Revolt, 84).

47. Letter of Wentworth to Monk, October 18, 1793, PAC Monk Papers, 295-298, quoted in Upton, Micmacs and Colonists, 83.

48. Lord Dorchester to Lieutenant-Governor Carleton, January 3, 1787. See Raymond, Winslow Papers, 339.

49. Upton, Micmacs and Colonists, 54.

50. Leacock and Laurie, North American Indians in Historical Perspective, 3.

51. See Hollingsworth, The Present State of Nova Scotia, 74, and Gesner, New Brunswick, 108.

52. Perley's Report of 1841, quoted in Hamilton and Spray, Source Materials Relating to the New Brunswick Indian, 93.

53. Patterson, The Canadian Indian, 117.

54. Hamilton and Spray, Source Materials Relating to the New Brunswick Indian, and $/ L A N S$, appendix 34, 1861, 2, cited in Ralston, "Religion, Public Policy, and Education of Micmac Indians," 189, and Patterson, The Canadian Indian, 118.

55. Huygue, Argimou, 4. The Halifax newspaper is quoted in Upton, Micmacs and Colonists, 131. Haliburton, An Historical and Statistical Account, 250. Haliburton noted, "intoxication is not general, a fact that cannot be affirmed of the population of Cape Breton generally, whose chief enjoyment appears to be derived from the latter source, with the honorable exception of the St. Ann's settlers, and in some measure of the French." 137.

56. Atkinson's Advice to Emigrants is cited in Upton, Micmacs and Colonists,

57. Gesner, New Brunswick, 114, 116.

58. Gesner, New Brunswick, 2: "their final release of the land of their forefathers, and their almost utter annihilation, are among those momentous events permitted by Providence for the extension of human industry and happiness ... it is [our] bounden duty ... to lessen their pains, and to bring into peace and contentment the Remnants of the tribes [we] have dispossessed of their unalienable rights."

59. Hollingsworth, The Present State of Nova Scotia, 76. Hollingsworth was pointing to a common colonial perception of non-Europeans.

60. Perley's Report of 1841, 7.

61. From a letter to the missionary Silas Rand, printed in the Christian Messenger, October 25, 1850. Cf. Upton, Micmacs and Colonists, 131. We might compare this with Haliburton's attempt at representing African Canadian speech during the same period: "only tink old Scippy see you once more. . . . How's Massy Sy, and Missy Sy. . . Oh I do lub em all." See Winks, The Blacks in Canada, 295.

62. Van Gennep, The Rites of Passage, 26, noted, "An individual or group that does not have an immediate right, by birth or through socially acquired attributes, to enter a particular house . . . is in a state of isolation. This isolation has two aspects, which may be found separately or in combination: such a person is weak, because he is outside a given group or society, but he is also strong because he is in the sacred realm with respect to the group's members. . . . In consequence, some people kill, strip, and mistreat a stranger without ceremony, while others fear him. ... For a great many peoples a stranger is . . endowed with magico-religious powers."

63. Lochhead and Souster, 100 Poems of Nineteenth Century Canada, 2. 
64. The Guardian, January 30, 1839, quoted in Upton, Micmacs and Colonists, 138. This tendency among colonizers to vilify those who are displaced and abused by the colonial process is considered by Michael Taussig, in Shamanism, Colonialism, and the Wild Man, 217. Taussig refers to a work entitled Voodoo in Haiti, in which Alfred Metraux suggests, "Man is never cruel with impunity; the anxiety which grows in the minds of those who abuse power often takes the form of imaginary terrors and demented obsessions. The master maltreated his slave, but feared his hatred. He treated him like a beast of burden but dreaded the occult powers which he imputed to him. And the greater the subjugation of the black, the more he inspired fear" (15).

65. Gesner, New Brunswick, 112, 116.

66. Hardy, Sporting Adventures, 36-37.

67. See White, "The Forms of Wildness," 7. Cf. Vaughan and Vaughan, Shakespeare's Caliban, 65-66: "Wildmen shot fireworks on the Thames during Anne Boleyn's 1533 coronation procession and frequently appeared in entertainments for Queen Elizabeth. In spectacles designed to celebrate the monarch's power, wisdom, and beauty, the wild man represented the natural forces she controlled. Her civilizing presence could tame the savage beast, just as her armies could tame the wilderness and her seamen could tame Spain's fleets." Robert Withington noted in the early part of this century that the figure of the wild man was a common participant in sixteenth-century drama and seventeenth-century Lord Mayor's shows in London. He was "dressed up to excite the interest which is provoked by a combination of terror and amusement" (English Pageantry: An Historical Outline, 72-74). For a description of the wild man's attire in public shows, see Strutt, The Sports and Pastimes of the People of England, 203. 260.

68. Halifax Recorder, July 26, 1860, 3, cited in Whitehead, The Old Man Told Us,

69. From Charles Churchill, Memorials of Missionary Life in Nova Scotia (1845), 188-189, cited in Whitehead, The Old Man Told Us, 216.

70. Herbert, Belinda Dalton. Cf. The introduction to Huygue's Argimou, iv, and Monkman, A Native Heritage, 168 n. 14.

71. See Pearce, Savagism and Civilization, 136, 138. Herri Baudet provides an excellent and extensive discussion of the development of the noble savage in the European imagination, in Paradise on Earth. He notes, for example, that in the eighteenth century, "the good savage was regarded not so much as a wholly 'noble' creature ... [as] instead the absolute criterion, a perfect example to be emulated" (43). Interestingly, the tradition of primitivism continues even today in "hobby clubs" of some European countries such as Germany, Italy, and Poland.

72. Pearce noted that in the American transcendentalist tradition, the destruction of aboriginal culture was regarded as inevitable, while, at the same time, the "natural life" of native peoples remained something to be upheld as valuable (Savagism and Civilization, 136, 147).

73. Huygue, Argimou, 1.

74. Huygue, Argimou, vi.

75. See Cogswell, "Literary Activity in the Maritime Provinces," 104.

76. Tuan, Man and Nature, 34.

77. Tuan, "Sacred Space," 92.

78. Acadian Recorder, February 24, 1849, quoted in Whitehead, The Old Man Told Us, 239. 
This page intentionally left blank 


\section{CHAPTER FOUR \\ THE BOUNDARIES OF PURITY}

OLONIAL Acadia posed a different problematic for the Mi'kmaq. The influx of peoples of British ancestry that began around the turn of the eighteenth century threatened, first, the native community's claim to be rightfully at home on the land desired by colonials and, subsequently, its liberty to exist at all in Acadia. For the Mi'kmaq, the problem was one of how to retain a sense of continuity of place and rootedness when these were placed in jeopardy by others' denial of the fundamental human significance of aboriginal peoples.

Like their British contemporaries, the $\mathrm{Mi}^{\prime} \mathrm{kmaq}$ experienced eighteenth-century Acadia in terms of ambiguity. A substantial ingress of Europeans did not begin until midway through the century, although settlers from Yorkshire, as well as the colonies of Massachusetts, Connecticut, and Rhode Island, had arrived prior to this. ${ }^{1}$ After 1750 , more considerable numbers began to arrive so that, by 1765 , five thousand New Englanders, four thousand Irish and Scots, and two thousand English-sponsored Germans and Swiss had settled in Acadia. ${ }^{2}$

Unlike the British, however, the Mi'kmaq did not tend to find ambiguity disconcerting. From at least as early as the mid-sixteenth century, they had been involved in a trade of furs with Frenchmen in which the French had been obliged to acquiesce to established $\mathrm{Mi}^{\prime} \mathrm{kmaq}$ modes of negotiating human ambiguity. ${ }^{3}$ Trade during this period was incorporated into an intricate system of reciprocity whereby the $\mathrm{Mi}^{\prime} \mathrm{kmaq}$ compelled the French to coalesce economic activity with 
exchanges of gifts, feasts, dancing, and mutual assertions and demonstrations of friendship. In 1606, for example, the French writer Marc Lescarbot ${ }^{4}$ described a feast attended by the Mi'kmaq chief Membertou and a French entrepreneur by the name of Jean de Biencourt de Poutrincourt, at which Membertou demanded that the Frenchman respect his community's established mode of doing business:

\begin{abstract}
During this gathering of people, it behoved to make presents unto him, and gifts of corn and beans, yea, some barrel of wine, to feast his friends. For he declared to Monsieur de Poutrincourt in these words: "I am the Sagamos of this country, and am esteemed to be thy friend and of all the Normans [Frenchmen] and that you make good reckoning of me. It would be a reproach unto me if I did not show the effects of this love. ${ }^{5}$
\end{abstract}

In a similar vein, the Jesuit Pierre Biard noted in 1613 that

gifts must be presented and speeches made to them, before they concede to trade; this done, they must have Tabagie, i.e. the Banquet. Then they will dance, make speeches, and sing ... that they are good friends, allies, associates, confederates, and comrades. ${ }^{6}$

The practice of exchange was the mode by which contact with other human beings was mediated. It assured that an element of mutuality would override experiences of human alterity and, so, constituted a constructive approach to the problem of ambiguity. It has been suggested that, "exchanges have a direct constraining effect: to accept a gift is to be bound to the giver. ${ }^{17}$ The $\mathrm{Mi}^{\prime} \mathrm{kmaq}$ entered into reciprocal relationships with others to ensure that human encounters with alterity could transpire without threat of violence. As Marcel Mauss once noted, "In order to trade, man must first lay down his spear ... it is only then that people can create, can satisfy their interests mutually and define them without recourse to arms. ${ }^{18}$

In this particular instance, the call for reciprocity appears to have functioned successfully. Numerous early Acadian traders, for instance, married native women, and chose to live alternately between their own and their wives' communities, ${ }^{9}$ and records exist of a number of French women who were fluently bilingual in French and Mi'kmaq. ${ }^{10}$ Clearly the $\mathrm{Mi}^{\prime}$ kmaq were not accustomed to turn away from human diversity; rather, they perceived in such diversity the potential for new relationships that could extend the boundaries of community, so long as there was an affirmation of the common significance of all people encountering one another. ${ }^{11}$

Beginning in the late seventeenth century, they encountered a new sort of European who refused to acknowledge their meaningful 
presence and, consequently, to enter into reciprocal relationships with them. For the Mi'kmaq, the significance of this foreign influx was rendered all the more incomprehensible by the rapidly evident disparity between colonial practice and the language of treaties. On paper, the British often affirmed the legitimate presence of Acadia's aboriginal peoples, but these, as noted earlier, were employed in the service of erecting boundaries between the two peoples. The Royal Proclamation of 1763 , for instance, declared:

The several Nations or Tribes of Indians with whom We are connected, and who live under our Protection, should not be molested or disturbed in the Possession of such Parts of our Dominions and Territories as ... reserved to them, or any of them, as their Hunting Grounds. ... We do hereby strictly forbid, on Pain of our Displeasure, all our loving Subjects from making any Purchases or Settlements whatever, or taking Possession of any of the Lands above reserved, without our special leave and License for that Purpose first obtained. ${ }^{12}$

In the idioms of both proclamation and treaty, the Mi'kmaq were promised "favour, Friendship, and Protection from His Majesty's Government, ${ }^{13}$ yet in the reality of the colonization process, no dictate could have been so meaningless. As one settler noted during the initial period of settlement, "our soldiers take great pains to drive the Indians away and clear the country of them."14

Attempts to "clear the country" of $\mathrm{Mi}^{\prime} \mathrm{kmaq}$ were varied. Throughout the 1830s until well into the 1850 s, colonial administrations employed companies of Boston Rangers /comprised of white volunteers and Mohawk retainers) to hunt the $\mathrm{Mi}^{\prime} \mathrm{kmaq}$. The value placed on the services of the Rangers was considerable, as Major Paul Mascarene, president of the Annapolis Council, pointed out in a letter to the Lords of Trade in 1744:

This shews how much the preservation of this place is owing to the Reinforcement we have received from the Province of the Massachusetts Bay, \& how necessary it is to set Indians against Indians; for tho' our men out do them in Bravery yet being unacquainted with their sculking way of fighting and Scorning to fight under cover, expose themselves too much to the Enemy's shot. ${ }^{15}$

Among the earliest victims of the Rangers were five Mi'kmaq women, two of whom were pregnant, and their three children. They were all massacred, and the pregnant women had "their bellies ripped open."16

Aside from the work of the Rangers, the local governments also took measures toward the extermination of the Mi'kmaq. A policy of poisoning the native population, for instance, can be traced to as early 
as 1712, when a group of $\mathrm{Mi}^{\prime} \mathrm{kmaq}$ were served poisoned food at a gathering sponsored by the British. ${ }^{17}$ In 1746 , two hundred Mi'kmaq died as a result of disease contracted from contaminated woollen cloth they had purchased from the British, ${ }^{18}$ and this strategy for their extermination was at least considered once again in 1763, when General Amherst suggested to one of his colonels, "Could it not be contrived to send the Small Pox among the disaffected tribes of Indians?" The answer to Amherst's query was "I will try to inoculate [them] with some blankets that may fall into their hands, and take care not to get the disease myself." The general in turn replied, "You will do well to try to inoculate the Indians by means of blankets." Whether their plan was ever actually realized is not known. ${ }^{19}$

As noted in the previous chapter, bounties on the $\mathrm{Mi}^{\prime} \mathrm{kmaq}$ and their scalps were in effect from at least as early as 1749 , when premiums were set at "Ten Guineas for every Indian Killed or Taken Prisoner," and were increased steadily until 1756, when Lawrence raised the bounty to "Thirty Pounds for every male Indian Prisoner, above the Age of Sixteen Years, brought in alive; for a Scalp of such Male Indians, Twenty-five Pounds." ${ }^{20}$ While the number of premiums actually claimed is unclear, it is certain that scalping of $\mathrm{Mi}^{\prime} \mathrm{kmaq}$ did occur during the period. In 1753, for instance, two whites arrived in Halifax with six scalps, and a year later, a crew of shipwrecked British privateers claimed their premiums for scalps they had removed from the Mi'kmaq who had saved their lives. ${ }^{21}$ Akins, in his History of Halifax City, also made a reference to the decapitation and scalping of three $\mathrm{Mi}^{\prime} \mathrm{kmaq}$ in the Dartmouth area during the same period. ${ }^{22}$

As long as the colonial population remained limited in size, the native community attempted with some success to arrest colonial expansion. In the early part of the century, British shipping and fishing were hampered, and, to a certain extent, settlement was impeded. ${ }^{23}$ In 1715 , a Mi'kmaq raid on the settlement of Canso resulted in the death of one Englishman, and the removal of all remaining settlers from the area. ${ }^{24}$ In 1732, the $\mathrm{Mi}^{\prime} \mathrm{kmaq}$ drove a group of New England settlers off the land near Minas, ${ }^{25}$ and according to an early nineteenth-century history of New Brunswick, early colonials who attempted to claim land along the St. John River were compelled by the resident native population to "retire further down the river." 26 The Mi'kmaq were also able to substantially control the expansion of Halifax beyond its initial boundaries until $1753 .{ }^{27}$ Despite these early successes, however, resistance to the British incursion slowed noticeably in the 1740s as French military strength in the region waned, and, after the fall of Louisbourg in 1758, all such resistance effectively ceased because the $\mathrm{Mi}^{\prime} \mathrm{kmaq}$ had lost their supplier of ammunition. ${ }^{28}$ 
Peace with Acadia's Mi'kmaq population was a consequence of their being outnumbered and militarily overwhelmed by a colonial population that had, from earliest contact, refused the possibility of reciprocity or mutual co-existence with aboriginal peoples. To the violence of dispossession, the $\mathrm{Mi}$ 'kmaq had responded in kind ${ }^{29}$ Although they had been successful for a period of time, they were ultimately trammelled in their attempt to assert themselves as significant and autonomous agents with a corresponding prerogative to claim Acadia as home. Arresting British expansion became an impossibility. By the time the $\mathrm{Mi}^{\prime} \mathrm{kmaq}$ were forced to accept this fact, they had been substantially alienated from their traditional modes of subsistence ${ }^{30}$ and compelled to petition colonial governments for land. In addition, the native population was becoming increasingly impoverished. In 1800, for example, the $\mathrm{Mi}^{\prime} \mathrm{kmaq}$ of Antigonish, Pomquet, and Tracadie were described as being "in a starving Condition and almost destitute of clothing." 31

As the possibility of stopping the British became less of an option, withstanding colonial pressure toward extinction became a necessity. One important mode by which the threat of annihilation might have been mitigated could have been the inducement of British colonials into recognizing the diverse human composition of Acadia as a context for new relationships. For aboriginal peoples, this was a traditional option that had not disappeared despite a century of conflict. In fact, the human devastation that had accompanied conflict served to demonstrate that the colonial notion of what constituted community in the New World was fundamentally flawed. Nineteenth-century Mi'kmaq consequently sought to acquaint the British with the diversity that characterized their world, in the hope of creating an authentic community in which all peoples might be afforded freedom from alienation. To do this, it was critical that they sustain a notion of the value of their own identity, and a sense of themselves as people who belonged in Acadia in spite of the historical experiences of marginalization and extermination. The symbols that permitted such a balancing act were the land and community.

The land was a foundation upon which the Mi'kmaq could assert the primordial fact of rootedness in Acadia. They possessed a relationship with place that preceded the arrival of Europeans, and so rendered meaningless those British valuations that sanctioned $\mathrm{Mi}^{\prime} \mathrm{kmaq}$ dispossession. This relationship with the land not only upheld the peoples' sense of identity, but constituted a vantage point for shaping a language about ambiguous meanings directed at the colonial population. The native community consequently availed itself-as often as was possible-of this reality of rootedness in their discourse with whites. In the 
eighteenth century, the $\mathrm{Mi}^{\prime} \mathrm{kmaq}$ had intermittently asserted a primordial relationship with the land when confronted with initial intrusions from British colonials. A group of elders and chiefs, for example, informed the colonial government early in the century that:

The place where you are building dwellings, where you are now building a fort, as it were, to enthrone yourself, this land of which you wish to make yourself now absolute master, this land belongs to me. I have come from it as certainly as the grass, it is the very place of my birth and of my dwelling, this land belongs to me ... it is God who has given it to me to be my country forever. ${ }^{32}$

During the same period, a man who had been captured for his part in a raid at Minas Basin declared, "This land here that God has given us .. . cannot be disputed by anyone. ${ }^{33}$

In the nineteenth century the $\mathrm{Mi}^{\prime} \mathrm{kmaq}$ became more vocal as they reminded colonials that the Mi'kmaq community possessed an intimacy with the landscape that whites did not share, and that this association derived of both the peoples' ancestors and the Creator. This continuity of place was asserted in arenas as varied as petitions to the colonial government, letters to the British Crown, and personal confrontations with settlers. In Prince Edward Island, a petition signed by five men in 1832 pleaded with the Assembly to return "a part of that land once our fathers, whereon we may raise our wigwams without disturbance. ${ }^{\prime 34}$ In 1840, London's Colonial Office received a letter addressed to the Queen, in which Chief Peminuit reminded her that the Acadian woods had all once belonged to the $\mathrm{Mi}^{\prime} \mathrm{kmaq}-$ "Our Fathers possessed them all"35 - and a petition from the Mi'kmaq at Burnt Church, New Brunswick, noted a few years later that "God did give [the Mi'kmaq] the land first. ${ }^{\prime \prime 66}$ In 1846, a white farmer attempted to reprimand an unidentified $\mathrm{Mi}^{\prime} \mathrm{kmaq}$, accusing the latter of damaging one of his trees. The man was said to have pointed to a five-hundredyear-old tree, saying,

If you raise a calf or a cabbage you may call it your own, but you can have no claim on that tree. . . That tree was planted by the Great Spirit for the [Mi'kmaq] before you and your fathers escaped from your murkey shells and crossed the great waters. ${ }^{37}$

Alongside this primordial relationship with land, commitment to the principle and actuality of community was a bulwark against extermination; it also contributed to a notion of human meaning that was quite distinct from the British tendency to marginalize human beings on the basis of their non-meaning. Ceremonies such as the celebration of St. Ann's Day consolidated resistance to British pressure for extinction and, at the same time, confirmed an identity born of human 
relationships. The annual gathering of $\mathrm{Mi}^{\prime} \mathrm{kmaq}$ peoples to celebrate the feast of St. Ann-the Grandmother-was, throughout the colonial period, a space in which the goals and values of the native community were expressed. Leaders' opinions came under public scrutiny, and they were expected to affirm their fidelity to the peoples' aspirations. ${ }^{38}$ The celebration was marked by feasting and song, as well as dancing that was regarded as a link between the $\mathrm{Mi}^{\prime} \mathrm{kmaq}$ and their ancestors. In 1850, a white observer, Silas Rand, remarked,

Part of the ceremonies of their great annual religious festival of St. Ann's day consists of the wigubaltimk and neskouwadijik, the feast and mystic dance of the sakawachkik, the Indians of olden times. At the proper time a chief comes out of a camp, sings ... dances ... and is responded to by ... the assembled crowd. They assert that during the ceremony the body of the dancer is impervious to a musket-ball. ${ }^{39}$

The relationship with a past that foreran the arrival of Europeans was, presumably, regarded as a more powerful source of identity than that which accompanied the violent onset of the colonial period, and it was this sense of meaning that permeated the celebration and the strategies for survival that the assemblage engendered. As one writer has noted, the annual gathering of the $\mathrm{Mi}^{\prime} \mathrm{kmaq}$ was a forum for exercising control in a historical situation in which the people were surrounded by forces of hostility. ${ }^{40}$

Integrity with respect to the welfare and values of the community was demanded always of those recognized as chiefs. It has been suggested that "only a forthright declaration of his intentions on behalf of his community's welfare could render a leader competent, in his band's estimation, to handle power." ${ }^{\prime 41}$ When, for instance, Chief Louis Benjamin Peminuit was given farm implements by the philanthropist Walter Bromley in $1817,,^{42}$ his authority was called into question by his community, and he was required to publicly recite a Profession of Faith at St. Ann's Day, whereby he affirmed his loyalty to the community he served. In a similar vein, a former chief from Bouctouche, New Brunswick, was obliged to spend the money he had made in a land sale on an ox for St. Ann's Day to demonstrate that he was innocent of alleged misconduct. ${ }^{43}$

The cultural weight afforded commitment to community was underscored in a great many of the peoples' stories. ${ }^{44}$ The primordial figure Gluskap, for instance, who will be considered at greater length below, was said to have been quite uncomfortable with human beings who were motivated by self-interest:

Three brothers came to [Gluskap], and they prayed him to make them tall, and give them great strength and long life exceeding that 
of men, and [Gluskap] was vexed with them, and said, "Probably you desire great strength and size that you may help others and benefit your tribe; and long life, that you may have much opportunity to do good to men." And they said, "We care not for others, neither do we seek the good of men; long life and strength and height are what we seek." Then he said, "Will you take for these success in fight, that you may be glorious in your tribe?" And they answered, "Nay, we have told you what we seek." Then he said, "Will you have, instead thereof, knowledge, that you may know sickness and the property of herbs, and so gain repute and heal men? ... Will you have wisdom and subtlety that you may excel in council?" And they answered him, "We have told thee what we seek. If thou will grant it, give. ..." Then [Gluskap] waxed angry, and said, "Go your ways; you shall have strength, and stature and length of days." And they left him rejoicing. But before they had proceeded far, their feet became rooted to the ground, and their legs stuck together, and their necks shot up, and they were turned into three cedar-trees, strong and tall, and enduring beyond the days of men, but destitute $\ldots$ of all use. ${ }^{45}$

In a similar story recorded by Leland in the 1880 s, four men sought out Gluskap in order to have their wishes granted. The first described himself as "a wicked man," who was easily angered, and he asked to be made good. The second asked to be given wealth because, although he worked hard, his poverty was acute. The third man felt alienated from people and wished only to be loved. All three were granted their desires. The fourth man was tall, handsome, and vain, and he asked that he be made the tallest man on earth, that he be permitted to live a very long time, and that his existence would never take him from the earth. This man was transformed into the first pine tree. ${ }^{46}$

Another story, related to the sportsman Campbell Hardy, spoke of a similar estrangement from other human beings that resulted from a concern only for one's own welfare. Michael Thom, a native guide employed by Cambell Hardy in the mid-nineteenth century, told Hardy of an old woman, the bear, who was blind and relied upon her companion, a handsome fisher, for food. He was a very astute moose-hunter, and each time he killed a moose he gave the old woman only the worst meat. One day, grandmother took a knife and cut deeply into the flesh over her eyes, restoring her sight, and subsequently discovering that Fisher had set all the fattest meat from his latest kill in a pile beside himself. She dissolved their partnership, and was shortly thereafter joined by another bear-"an able-looking man [who was] so strong he could catch anything at all." Fisher, however, was doomed to remain alone. $^{47}$

The significance afforded both the relationship with land and with community suggested a mode of valuation in absolute opposition 
to the colonial values that gave rise to alienation and devaluation of human beings. For many people, the possibility of inducing the British to alter these values appeared to be contingent upon simply pointing out their failure to function reciprocally. The Mi'kmaq knew that without mutuality, human life was problematic. They also knew that, unless the British were made aware of this fact, their own existence would become increasingly precarious. Thus, they persistently called the British to confront the incongruity of their behaviour, and the flawed valuational framework from which such behaviour emerged. They pointed in some instances to the inequity of relations between the native and white communities, such that, as one man noted in 1846, "We never injure your pigs nor cows; but the other day your men frightened a bear, and prevented him from going into my trap. ${ }^{\prime 48} \mathrm{At}$ other times, the fundamental injustice of British expectations was criticized, as when Chief Peminuit told the Queen:

When I was young I had plenty; now I am old, poor, and sickly too. My people are poor. No hunting Grounds-no Beaver-no Otterno nothing. ... All these woods once ours. ... Now we cannot cut a Tree to warm our Wigwam in Winter unless the White Man please. ${ }^{49}$

Still in other instances, the Mi'kmaq hoped that by demonstrating their commitment to the principle of reciprocity, the British might be moved to do the same. The petitioners from Burnt Church (noted previously) did precisely this in their correspondence with the colonial government:

[The Mi'kmaq] have never broken their word, but have been true and Loyal Subjects and therefore trust that you the Representatives of their Great Mistress the Queen will never consent to break their Location or abridge their privileges in any manner whatever. ${ }^{50}$

Throughout the period in question, native affirmations of identity not only constituted a means of withstanding pressure for extinction, but demonstrated an astute understanding of the diverse character of Acadia. This clarity of vision ultimately pervaded all aspects of their contest with the colonial world. Indeed, their survival depended upon it. Despite frequent British disparagement to the contrary, the $\mathrm{Mi}^{\prime} \mathrm{kmaq}$ vigorously sought modes of subsistence that could accommodate the changes that the European presence had provoked in Acadia; they adapted as much as the British would permit to the demands of a colonial economy. From the late eighteenth century onward, entire communities often relocated near white settlements in the summers in order to sell crafted items to the white population. Women supplied whites with a variety of such items, including woven baskets, quill 
boxes, and brooms. Men pursued various occupations in addition to their traditional-although vastly attenuated-practices of hunting and fishing. They constructed wooden barrels and butter tubs, as well as ax handles to supply to whites. ${ }^{51}$ Moses Perley noted in his Report of 1841 that at the Eel Ground Reserve "some work as Coopers and make very good articles. ${ }^{\prime 52}$ In other areas, they worked in the logging and lumbering industries, ${ }^{53}$ and a substantial number hired themselves out as guides for European and American game hunters and tourists who began arriving in relatively substantial numbers in the $1840 \mathrm{~s}$. The influx of sportsmen into Acadia began largely as a result of the publication of a letter written by Moses Perley in the London Sporting Review in 1839 , in which he extolled the region's potential for game hunting. ${ }^{54}$

Porpoise hunting was also an alternative pursued by the $\mathrm{Mi}^{\prime} \mathrm{kmaq}$ throughout the century, and remained a viable undertaking until the turn of the twentieth century, when petroleum oils replaced that derived from porpoise blubber as a principal industrial lubricant. This work was extremely difficult. Porpoise hunting in Digby County, for instance, lasted for about two and a half months each summer, during which time entire communities relocated themselves in areas along the coast. Each canoe brought in about six porpoises per day during the season, although adept fishermen could often bring in as many as twelve. The blubber of the animals was removed and allowed to dry before being boiled into oil and kegged. When there was sufficient oil to fill a canoe, the load would be taken either to Digby or to wholesalers in St. John. ${ }^{55}$

The understanding of Acadia's altered character extended beyond Mi'kmaq modes of subsistence. Again, despite an ineffectual colonial response, frequent expressions of a desire for access to English literacy and agricultural expertise occurred throughout the nineteenth century. As early as 1804 , Edward Winslow was informed that the $\mathrm{Mi}^{\prime} \mathrm{kmaq}$ of New Brunswick

are at present discontented and discouraged. There is a school established at Sussex Vale, but what is that, as they observe, to their numerous tribe and the distribution of their nation; they are scattered and dispersed to several parts on this river for the sake of supporting their distressed families, and if schools were to be established once more, it would . . be the means of bettering their condition. $^{56}$

Legislative reports from the early 1840 s onward pointed especially to the fact that many $\mathrm{Mi}^{\prime} \mathrm{kmaq}$ were inclined to regard an English education as a positive thing, ${ }^{57}$ and some communities went so far as to request the construction of schools and the provision of white teachers. ${ }^{58}$ 
The desire to enter into agricultural production was asserted more vociferously. Early in the century, Chief André Muis (whom the missionary John West called Adelah/ travelled to London to have a land grant confirmed so that his community might begin to farm extensively. ${ }^{59}$ In 1838, Chief Oliver Thomas Le Bone wrote to the Colonial Office from Prince Edward Island stating that, as a result of an acute shortage of game, his community was prepared to attempt agriculture as a means of supporting themselves. ${ }^{60} \mathrm{~A}$ few years later, Perley reported that the $\mathrm{Mi}^{\prime} \mathrm{kmaq}$ with whom he had recently spoken "seemed quite willing to become farmers provided they had some persons to ... teach them in the first instance, and provided also, they could raise enough from the land to support them. ${ }^{\prime \prime 1}$ In 1844, Joseph Howe's report to the Nova Scotia Legislative Assembly related how,

Early in the spring, two Indians from Queen's County had visited me in Halifax, representing their anxiety to settle and become Farmers, if they could get land. .. John Jeremy informed me that he had selected a spot on the Fairy Lake, but was afraid to improve or build, unless he was assured that he would not be disturbed.62

And when, in 1860, the Prince of Wales visited Charlottetown, he was met by a delegation of $\mathrm{Mi}^{\prime} \mathrm{kmaq}$ requesting assistance for establishing themselves as farmers. ${ }^{63}$

Despite all these attempts to adjust to Acadia's settler economy, the Mi'kmaq continued to starve. The British population itself was generally uninterested in the reality of the devastation that settlement was causing, and so the Mi'kmaq tried consistently to elicit a response from governing bodies. Their petitions, worded in English and issued through proper administrative channels, were an attempt to fashion their pleas for recognition in conformity to the expectations of those who supposedly exerted some influence over the settlers. When these initiatives failed to move colonial administrators, the $\mathrm{Mi}^{\prime} \mathrm{kmaq}$ often circumvented colonial governments entirely, and addressed their communication to the British government or the Crown. They understood the nature of the bureaucracy they faced, and when formal channels floundered, they sought out the administrator's superiors.

The colonial British attempted from earliest contact to alienate aboriginal peoples, and to deny the possibility of a mutually created community. As a consequence of this attempt to render them invisible, the $\mathrm{Mi}^{\prime} \mathrm{kmaq}$ perceived the importance of visibility in respect to bringing about a British recognition of the diversity that defined the Acadian community. Thus, they appeared in public celebrations in which, as we noted earlier, they were appreciated by whites for little more than their entertainment value. Regardless of white motives for seeking their 
inclusion on these occasions, visibility was still visibility; alienation of the $\mathrm{Mi}^{\prime} \mathrm{kmaq}$ was a dismal reality, and the native community consequently exploited all opportunities for potential discourse with the white population. When Queen Victoria's marriage was commemorated by Nova Scotia in 1840 , a group of $\mathrm{Mi}^{\prime} \mathrm{kmaq}$ walked in procession through the streets of Halifax. One newspaper noted that they were adorned "with badges, ribbons, flowers and Indian ornaments . . . boys with bows and arrows and badges ... female Indians with their picturesque costume of high peaked caps, and various ornaments." Following the parade, its organizers set up tables and served a meal to the aboriginal participants, who ate under the watchful eyes of interested observers. ${ }^{64}$

The Mi'kmaq were impelled, in their struggle against extinction, to come face to face with the profile of colonial Acadia. In their pursuit of modes of subsistence, they exploited every niche in the settler economy that had not been closed to them. They adopted modes of formal communication that the British expected, and they recognized the authority of those who constituted the colonies' political elites. Aware that invisibility would render impossible the task of bringing the colonials to a consciousness of Acadia's diverse profile, the Mi'kmaq even exploited opportunities for public exposure that whites perceived as spectacle. Survival required of native peoples a clear understanding of the reality of a changed homeland. Acquiescing to reality, however, did not signify an acceptance of the cultural meanings that had nourished the changes.

The Mi'kmaq had to eat. Adjustment to structures of power in Acadia was consequently absolutely necessary. But these adjustments were not regarded by any stretch of the imagination as modes of becoming British or of adopting the identity of a human community that wandered about the globe wreaking cultural and physical destruction. Native peoples accommodated themselves to colonial valuations in order to live, but their accommodation always contained an element of critique that pointed to the symbols of land or community as the measure of ultimate meaning and, consequently, of being $\mathrm{Mi}^{\prime} \mathrm{kmaq}$.

They took part, for instance, in colonial exhibitions in the interest of gaining visibility, but they had no respect for the lens of exoticism through which the white population regarded them. A story told to Silas Rand in the late nineteenth century demonstrated an intensely critical analysis of the orchestrated spectacle of events such as Queen Victoria's parade.

Shortly after the country was discovered by the French, an Indian named Silmoodawa was taken to Planchean (France) as a curiosity. 


\begin{abstract}
Among other curious adventures, he was prevailed upon to exhibit the Indian mode of killing and curing game. A fat ox or deer was brought out of a beautiful park and handed over to the Indian; he was provided with all the necessary implements, and placed within an enclosure of ropes, through which no person was allowed to pass, but around which multitudes were gathered to witness the butchering operations.... He shot the animal with a bow, bled him, skinned and dressed him, sliced up the meat, and spread it out on flakes to dry; then he cooked a portion and ate it, and in order to exhibit the whole process, and to take a mischievous revenge upon them for making an exhibition of him, he went into a corner of the yard and eased himself before them all. ${ }^{65}$
\end{abstract}

For the man in this story, the land was intricately entwined in human life; it could not be made into a backdrop for life as performance. ${ }^{66}$

In addition to public appearances, it is also true that the $\mathrm{Mi}^{\prime} \mathrm{kmaq}$ often expressed interest in learning the English language, as well as learning agricultural skills, from the white community; but these were pragmatic means pursued to alleviate their extreme destitution, not overtures (as some colonials like Moses Perley presumed) toward a colonial identity. ${ }^{67}$ As noted earlier, Edward Winslow was informed at the turn of the nineteenth century that New Brunswick's Mi'kmaq population was "discouraged" and "distressed," and very much desired access to British-sponsored education. ${ }^{68}$ John West noted in his Journal of a Mission to the Indians of the British Provinces that André Muis had told him he wished to begin farming in order to "see his Indians, with their families, in better circumstances. ${ }^{169}$ Despite the desire for access to some aspects of white culture (eating being a principal one), the nineteenth-century $\mathrm{Mi}^{\prime} \mathrm{kmaq}$ exercised extreme caution when considering the potential impact of these actions upon their sense of community. Thus, although in many cases they wished to undertake agriculture, for instance, they would not conform to a colonial style of farming in which people were no longer responsible for the welfare of any but themselves; and they persistently opposed colonial plans to subdivide their land for the use of individual families. ${ }^{70}$ Similarly, while they expressed interest in learning the English language, many resisted the notion of educating their children in white schools. The utility of a British education was regarded with skepticism, as a process that would undoubtedly echo the values of people who were adverse to acknowledging their interrelationship with others. Children inculcated with such values could well have proven to be destructive agents within their own communities. This caution was reflected in a letter received by Joseph Howe in 1842 from a colleague who had been told by a man named John Lupin that his community

disapproved of their children being educated in the white man's schools, because when so educated it would break off the natural 
ties of affection and association between them and their tribes, and mutual contempt and dislike would be the result. ${ }^{71}$

This duality of meanings was also reflected in the writing of formal petitions. While acknowledging the fact that a particular form of correspondence was best suited to dealing with colonial governments, these petitions nonetheless contained calls for mutual respect and reciprocity not present in colonial European culture.

All this is to say that for aboriginal peoples, colonial Acadia was a fact; it was no longer the world the Mi'kmaq had known. Their task was to deal with the reality of a historical situation while maintaining a sense of identity that was distinct from the experience of alienation. In potential service of the world in which they lived, they not only accomplished this task but, in so doing, reimagined a colonial society that could take account of both historical experience and the fundamental value of all human beings. This world was given life in the stories they told that were constructed on a motif of cultural contact.

Rand learned, for instance, that there had once been a very poor young man who left his home in search of relief from his poverty. $\mathrm{He}$ made his way to a royal city where he found employment with the king's grooms. After two years of service, he introduced himself to the king who was so impressed with the young man's aristocratic demeanour that he hired him as his personal attendant, believing the groom was of royal lineage. The king's daughter fell in love with the man the moment they met and they were subsequently married. No one in the entire city (least of all the king) ever suspected that the young man was anything but royalty. ${ }^{72}$ Mutuality, it appears, was regarded as a fundamental way of dealing with human diversity, and economic and social distinctions were clearly no more than the stuff that obscured that reality.

Rand was also told of two brothers who set out in search of a new home following the death of their parents and five siblings. When they reached a city, they were asked by passers-by from where they had come, what they did for a living, and their reason for being in the city. They explained that they were very poor, that the younger brother knew medicines and could heal, and that the elder brother was a labourer who desired only to work. The king, whose son was very ill, heard of the two brothers and summoned them to his home. The younger brother cured the child and was given half the territory ruled by the appreciative father. As his only desire was to spend the remainder of his life teaching others to heal, the young man gave his gift to his brother, and they both went on to become very rich men who used their wealth for the good of the people who resided in their new county. 
The relationship between the two parts of the region was harmonious, with the elder brother ruling both segments following the death of the old king, and when the young son was sufficiently mature to bear the responsibility, the brother passed the king's half back to him. ${ }^{73}$ This was, in a sense, what might have been in Acadia. It was a story of encounter with alterity that led to a reciprocal relationship in which all people were recognized as significant human beings with responsibility for the welfare of all others. And all lives were consequently enriched by the encounter.

Re-imagining the world so as to concede to history its reality as well as its potential as a context for the affirmation of human significance was possible for the $\mathrm{Mi}^{\prime} \mathrm{kmaq}$ because they did not regard identity as self-generated. There was a primordial construction to their sense of meaning that, like the British identity, was rooted outside the colonial world, but it was structured in such a way as to remain somehow contingent upon human experience. In many respects, it was summarily framed in the figure of Gluskap-the primordial man who had been born before other human beings "knew themselves, in the light before the sun." ${ }^{174}$ Gluskap had come to earth from the realm of the spiritual, ${ }^{75}$ but his relationship with the land was of profound intimacy. His family included some of the earth's creatures (his uncle, for instance, was Turtle $\mid{ }^{76}$ his canoe was a granite island, ${ }^{77}$ and he enjoyed an affinity with animals that brought bears and wolves to lick his hands and moose and caribou to wander about his home like domestic animals. According to Michael Thom, Gluskap

charmed [the animals] with his pipe. Sometimes he would go out into the stillness of a summer's evening, and play upon his shrilltoned instrument. The music could be heard at an immense distance.... Charmed with the melody, all the animals within hearing would immediately set off for his dwelling. ${ }^{78}$

In the context of the forest, he fasted and dreamed, and in so doing, acquired a form of power not available within the realm of pure earthly existence. Charles Leland, in his interpretation of stories of Gluskap collected in the late nineteenth century, wrote that "to gain tremendous power ... as man had never won," Gluskap was obliged to "dwell in the wilderness, and fast and pray and dream. ${ }^{779}$ In the wake of these experiences, he was able to bring his two closest companions-Grandmother and Marten-back from death. ${ }^{80}$ It was Gluskap who was said by many to have named everything on earth, and to have given life to human beings. ${ }^{81}$

The Mi'kmaq were thus born of an intimacy between the physical and cosmic worlds. ${ }^{82}$ Identity was not internally generated but was a 
product of the encounter of the world of the spirit with the world of experience. The latter portion of the equation situated human meaning in relation to historical processes. Consequently, for the nineteenthcentury $\mathrm{Mi}^{\prime} \mathrm{kmaq}$, their identity had come into existence before colonialism, but it could not exist apart from the historical reality of the colonial world. In fact, the New World itself came to be afforded a primordial basis that conceded the reality of the changes initiated by the European movement across the Atlantic.

Gluskap had spoken of the future arrival of Europeans in Acadia, and had prophesied the baptism of the Mi'kmaq. ${ }^{83} \mathrm{~F}$. G. Speck was told by Chief Joe Julien and John Joe (of Sydney and Whycogamagh, respectively) that Gluskap and Christ had toyed with Acadia's landscape long before the Christians themselves left Europe:

[Christ] took Gluscap to the ocean, and told him to close his eyes. Then Christ moved close to the shore an island which lay far out to sea. When Gluscap opened his eyes, he saw it. Christ asked him if he could do as much as that. Then Gluscap told Christ to close his eyes a while. When Christ opened his eyes, he found that Gluscap had moved it back to its place again. ${ }^{84}$

Gluskap's people were firmly Mi'kmaq, but this did not preclude the historical reality of becoming also New World people.

Eighteenth- and nineteenth-century Acadia was very much a new place for its aboriginal peoples. Unlike the British, the $\mathrm{Mi}^{\prime} \mathrm{kmaq}$ did not deny this fact. They did, however, recognize that the changes that had occurred had a devastating impact on a large measure of Acadia's human profile, and so they sought new possibilities for being New World humans that would take account of the reality of change while affirming the integrity of all peoples. Where the British regarded diversity as destructive to their pattern of meaning, the Mi'kmaq saw it as a context for extending a pattern. The fundamental divergence here was between a notion of identity as something self-generated, and a recognition of power other than the human, which shaped both experience and meaning. The colonial as purely British was a construction of the imagination, an internal structuring of identity that was projected outward and imposed upon a historical reality that itself rendered such a construction an impossibility. The land, other humans, indeed history itself became incidental to the meaning of the colonial, for this person could be shaped and defined by little beyond its own conceptions. The ambiguities of experience-whether they involved the situation of the colonial on land three thousand miles removed from England or the existence of other communities of human beings who called Acadia "home"-were not permitted to enter into the arenas of 
colonial definition, because these would invariably have confronted the British with an identity imposed by something other than themselves.

For aboriginal peoples, on the other hand, a relationship with land and community sustained a sense of identity that was $\mathrm{Mi}^{\prime} \mathrm{kmaq}$-an identity brought to life in the meeting of the physical and spiritual worlds. A relationship with Europeans gave rise to a sense of identity that was "New World," and this was born in the historical encounters of the post-Colombian period. For the Mi'kmaq, both identities coexisted. Being $\mathrm{Mi}^{\prime} \mathrm{kmaq}$ did not signify a rupture with the reality of being entrenched in a colonial world, but neither could being New World people negate the notion of humanity contained in being Mi'kmaq. ${ }^{85}$

This duality afforded aboriginal peoples a vision of themselves with which they could withstand the pressure to become extensions of the British imagination that sought to make of them either British clones or dead $\mathrm{Mi}^{\prime} \mathrm{kmaq}$. It also gave rise to an understanding of the British that the colonials themselves failed to achieve. The stories of Gluskap's prophesies, and of his primordial contest with Christ, for instance, were articulations of this understanding, for these suggested that the British did not know themselves. Their adamant contentions of cultural purity were lies that obscured their ability to recognize that they were part of a structure of meaning that was much greater than they imagined. The Mi'kmaq knew that the world of the British was not all there was. They also knew that while there might well be power in coercion and violence, there was another form of power in knowing that humans do not create themselves nor the world about them.

In ascribing names to everything, Gluskap had conferred upon the creation inhabited by the $\mathrm{Mi}^{\prime} \mathrm{kmaq}$ a structure of meaning not governed by the human agents within the world. To name something is to control its significance and since, for the $\mathrm{Mi}^{\prime} \mathrm{kmaq}$, this power was located in the primordium, human beings who sought to exercise this sort of prerogative in Acadia were deluded in their sense of self-importance. In the latter part of the colonial period, a story was told that underlined this form of self-deception. It described the meeting of the first colonial priest and a shaman, in which the European asked,

"What name would you like to have?" "Mary." "No; that is a woman's name. Try again." "God." "No; God has charge of us all." "Devil." "No; he takes care of Hell." Finally the priest left him, for he could not get any satisfaction. ${ }^{86}$

The world, for the Mi'kmaq, was not a human creation. Further, any power the human possessed was likewise not self-engendered. 
Gluskap once travelled across the Atlantic and landed on an island off the coast of England.

The King ordered a man to try to find the man who was in charge there. A ship was sent out ... they found a man there and asked him, "Where are you from?" "I am from out there," said Gluskap, pointing westward. "Do you intend to remain here?" "To be sure, I shall stay here...." The English began cutting wood, to put in their ship. He told them not to do so-"All the wood on the island belongs to me." The King sent the ship back to get the man. The Captain went ashore and said to him, "Come aboard; the King wishes to see you. We will put you ashore." "No; go back; tomorrow morning I shall be there." They reported his words to the King. On the following morning it was found that the island was close to the shore.... The King threatened to kill [Gluskap] when he did come ashore ... accordingly, the King built a big pile of wood and had ready for use a huge flask of oil. .. . Two officers took him, handcuffed him, and put him on the pile of wood. Fire was placed to it. It blazed high, and finally the pile was burned to the bottom. When it had burned out, Gluskap was found sitting in the midst of it, just as they had placed him, smoking his pipe.... Gluskap walked out and asked, "Where is the King?" The King was called. He went to Gluskap and wished to shake hands with him. Gluskap said, "I cannot touch your hand, for it is of no account-it is like yourself. You, too, are no good; you are a very hard-hearted man. ... When you called me from out there, I thought you would accord me better treatment than I have received..." The King then knelt before him. "Get up," said Gluskap; "I don't want that. But do not treat people in such manner as you have treated me. .. You may be the Master of this world, but there is another who is Master over you. I shall leave you now. If I had not shown myself more powerful than you, you would have killed me. But even I, as well as yourself, have a Master. ${ }^{187}$

In failing to acknowledge a power greater than himself, the "King of England" existed in a world of illusion that Gluskap exposed. The Mi'kmaq shared Gluskap's experience of the destructive potential of self-generated identity.

In the war that was the greater part of the eighteenth century, they chose violence only after the possibility of reciprocity was rejected by the British. As human beings they imagined their identity in relation to forces beyond themselves and, consequently, possessed the power to encounter diversity without resorting to violence. This was the power to experience the freedom that originates in the extension, rather than the constraint of human meaning.

\section{Notes}

1. See MacDonald, Rebels and Royalists, 10; Moir, The Church in the British Era, 17-18; Stewart, Documents Relating to the Great Awakening, xv. 
2. For references to the New England immigration, see Reid, Six Crucial Decades, 50. The Irish, Scottish, and German influx is considered by Guillemin, in Urban Renegades, 52-53; Collections of the Nova Scotia Historical Society vol. 8 (1892-1894): 251; Reid, 50, MacNutt, The Atlantic Provinces, 55.

3. Morrison notes that trade in the region was being conducted at least as early as the 1550s from Tadoussac on the Saguenay River (see The Embattled Northeast, 18). However, it may well be that it began earlier than this. By the time Jacques Cartier arrived in 1534, the native population was sufficiently familiar with French commercial interests to greet the Frenchman with "frequent signs to us to come ashore, holding up to us some furs on sticks." See Biggar, The Voyages of Jacques Cartier, 49. For discussion of the early trade period see Eccles, The Canadian Frontier, esp.16-20; Innis, The Fur Trade in Canada, 9-12; Jennings, The Invasion of America, 95-96; Guillemin, Urban Renegades, 23; Bailey, The Conflict of European and Eastern Algonkian Cultures, 6ff.; Trigger, The Indians and the Heroic Age of New France, 9ff.; Leacock and Laurie, North American Indians in Historical Perspective, 350-351.

4. Lescarbot was a disillusioned French lawyer who sailed to Acadia in 1606 to satisfy his curiosity about the New World. Along with the Jesuit Relations of the period, his work, Nova Francia, remains the most comprehensive early European document concerning the early period of European-Mi'kmaq contact in the region. See Sauer, Seventeenth Century North America, 84.

5. Lescarbot, Nova Francia, 129-130.

6. Thwaites, The Jesuit Relations and Allied Documents, vol. 2, 81.

7. Van Gennep, The Rites of Passage, 29. Marcel Mauss also suggested that this property of the gift permits it to exert a "religious hold over the recipient." See The Gift, 10.

8. Mauss, The Gift, 80 .

9. See Upton, Micmacs and Colonists, 26. References to actual marriages recorded in the Quebec archives are provided in Griffiths, The Acadians, 3. Nash, Red, White and Black, suggests that intermarriage in Acadia was a particularly pervasive phenomenon, so that by the late seventeenth century almost every French family established in the region could claim lineages that included native peoples (104-105). The notion of intermarriage remained a relatively innocuous one throughout the colonial period, as the $\mathrm{Mi}^{\prime} \mathrm{kmaq}$ did not share the British repulsion of the practice. In fact, in the mid-nineteenth century, Michael Thom told Campbell Hardy a story that appeared to poke fun at the colonial aversion to ethnic mixing: "That rabbit queer fellow! He got married at last. He marry the Martin. He thought she very good woman at first; for he marry in winter, you know. But ... when the warm weather come on, she change colour, and then he shocking angry. He find he been and married coloured woman. Poor Ablegemuich" (Sporting Adventures, 258).

10. See Bailey, The Conflict of European and Eastern Algonkian Cultures, 121. Bailey refers to the wife of an army officer stationed on the St. John River in 1699. Dickason, "From One Nation in the Northeast to 'New Nation' in the Northwest," 9. Dickason points out that the wife of Louis Du Pont Duchambon lan acting governor of Louisbourg from 1744 to 1745 ) worked as an interpreter.

11. The nineteenth-century historian Thomas Akins referred in his History of Halifax City to "a little work, now a scarce book, published during the second siege of Louisburg," in which the French author (probably Thomas Pichon) noted: "force will never do; they [the Mi'kmaq] will yield to nothing but persuasion . . you must gain their esteem, for they never confide in a person whom they do not value." Akins, 35; Pichon, Letters and Memoirs, 115. Cf. Chute, "Ceremony, Social Revitalization, and Change," 52. 
12. The proclamation appears in Miller, Skyscrapers Hide the Heavens, 71 . Subsequent instructions to Governor Murray in December of 1763 reiterated much of this: "Whereas We have, by Our Proclamation dated the seventh day of October in the Third Year of Our Reign, strictly forbid, on Pain of Our Displeasure, all our Subjects from making any purchases or settlements whatever ... no private person, Society, Corporation, or Colony [may] be capable of acquiring any Property belonging in Lands belonging to the Indians." Instructions to Murray, December 7, 1763, printed in Smith, Canadian Indians and the Law, 5-11. Smith deals with the proclamation itself in the preceding pages.

13. From the Treaty of 1752 , quoted in Battiste, "An Historical Investigation of the Social and Cultural Consequences of Micmac Literacy," 139.

14. See Murdoch, History of Nova Scotia, vol. 2, 201, and Miller, "The Decline of the Nova Scotia Micmac," 110.

15. Governor Mascarene to the Lords of Trade, September 25, 1744, cited in Akins, Selections from the Public Documents of the Province of Nova Scotia, 133-134. In his History of Halifax City, Akins claimed that "During the Indian hostilities, opposition on the part of the Colonists was altogether of a defensive nature. The regular troops, as well as the undisciplined militia, proving unfit for such warfare, it was found necessary to employ the New England Rangers. These were volunteers from the New York provinces, accustomed to Indian warfare, many of them Indians and half-bloods. They ascended the rivers, penetrated into the heart of the province, and attacked the enemy in their strongholds" (35). Cf. Upton, Micmacs and Colonists, 45-47.

16. See Maillard, An Account of the Customs and Manners of the Micmakis and Maricheets, 62-63. Cf. Whitehead, The Old Man Told Us, 102; Upton, Micmacs and Colonists, 46-47; Miller, "The Decline of the Nova Scotia Micmac," 108-109.

17. Miller, "The Decline of the Nova Scotia Micmac," 108.

18. For references to this instance of poisoning, see Johnston, A History of the Catholic Church, 67-68; Miller, "The Decline of the Nova Scotia Micmac," 109; and Pichon, Letters and Memoirs, 164.

19. See Johnston, A History of the Catholic Church, 68. Cf. Miller, "The Decline of the Nova Scotia Micmac," 110.

20. The 1749 rewards were set in Premium for Dead Indians; Supplies to be Purchased, tabled at a council meeting, October 1, 1749; quoted in Whitehead, The Old Man Told Us, 115. Cf Reid, Six Crucial Decades, 37; Patterson, The Canadian Indian, 63. Lawrence's subsequent directive is quoted in Murdoch, History of Nova Scotia, 308, and Hamilton and Spray, Source Materials Relating to the New Brunswick Indian, 23. Bounties on the scalps of other native peoples in the Northeast were in effect from the late seventeenth century onward. The colony of Massachusettes was paying bounties in 1694, and that of Connecticut, in 1746. See McLennan, Louisbourg from Its Foundations to Its Fall, 424-425; Dickason, "Louisbourg and the Indians," 99-100.

21. Haliburton referred to the two men by name-john Connor and James Grace-in An Historical and Statistical Account, 154. Cf. Whitehead, The Old Man Told Us, 129, and Upton, Micmacs and Colonists, 55.

22. Akins, History of Halifax City, 18.

23. See Dickason, "Frontiers in Transition," 27, and Reid, Six Crucial Decades, 36.

24. Upton, Micmacs and Colonists, 40.

25. Upton, Micmacs and Colonists, 45.

26. Fisher, The First History of New Brunswick, 115-116. 
27. Reid, Six Crucial Decades, 36-37. Dickason notes, for example, that the Mi'kmaq responded to Cornwallis's formal statement of antagonism with a similar declaration of war. See "Frontiers in Transition," 27, n. 18.

28. See Patterson, The Canadian Indian, 63; Hamilton and Spray, Source Materials Relating to the New Brunswick Indian, 22; Jennings, Empire of Fortune, 185; Upton, Micmacs and Colonists, 57 . For specific references to subsequent treaty negotiations, see Hamilton and Spray, 23, 35; and Upton, 58.

29. Francis Jennings has suggested that Abenaki, Mi'kmaq, Iroquois, and Ohio violence during this stage of colonization was clearly a response to colonial encroachment (Empire of Fortune, 219, The Invasion of America, 37). Cf. Patterson, The Canadian Indian, 61.

30. For a discussion of the cyclical pattern of subsistence carried on by the $\mathrm{Mi}^{\prime} \mathrm{kmaq}$ prior to the arrival of the British, see Father Pierre Biard's account in Thwaites, The lesuit Relations, vol. 3, 79-83; Denys, The Description and Natural History of the Coasts of North America (Acadia), 428-435; and Upton, 2-3.

31. From a petition made by David Marc Antoine, ILANS, April 2, 1800, cited in Whitehead, The Old Man Told Us, 114. In reference to the depletion of the Mi'kmaq subsistence base, see Dickason, "Frontiers in Transition," 28.

32. From a letter transcribed by Maillard from the Mi'kmaq representatives to the governor at Halifax, October 18,1749, translated by Upton, Micmacs and Colonists, 201-202.

\section{Reid, Six Crucial Decades, 36.}

34. Petition of Louis Francis Alguimou, Piel Jacques, Oliver Thoma, Peter Tony, and Michael Mitchel; in the Journals of the Legislative Assembly of Prince Edward Island, 1832, 11, cited in Whitehead, The Old Man Told Us, 208.

35. Petition of Chief Pemmeenauweet, CO.217/179, 406-408, cited in Upton, Micmacs and Colonists, 134.

36. Provincial Archives of New Brunswick (PANB), Rex/Px, vol. 40, 167, quoted in Hamilton and Spray, Source Materials Relating to the New Brunswick Indian, 126.

37. This was reported by the Reverand John Sprott, and printed in The Nova Scotian, April 6, 1846, 10, cited in Whitehead, The Old Man Told Us, 228.

38. See Chute, "Ceremony, Social Revitalization, and Change," 58.

39. Rand, A Short History of Facts, 14. Cf. Webster's introduction to Rand's Legends of the Micmacs, xxxi. The sportsman Charles Halleck described what he saw of the festivities at St. Ann's Day, in "The Restigouche," 431-432.

40. Chute, "Ceremony, Social Revitalization, and Change," 54.

41. Ibid., 55 .

42. Walter Bromley, a British military officer who retired to Nova Scotia in 1813, was considered by his white contemporaries to be "one of the greatest philanthropists of the age." He involved himself in initiatives intended to demonstrate the feasibility of teaching the $\mathrm{Mi}^{\prime} \mathrm{kmaq}$ trades, farming, the Protestant faith, and the English language. His pilot project was located at Shubenacadie and was run much like a military operation in which families were threatened with losses of rations if they failed to cultivate sufficient land. See Fingard, "English Humanitarianism and the Colonial Mind," 127-149.

43. Chute, "Ceremony, Social Revitalization, and Change," 55-56.

44. These have often been designated as legends or folklore by whites who recorded them; but I prefer to consider the stories under the rubric of myth, in recognition 
of their primordial structures of meaning (as noted in chapter one). In choosing to avail ourselves of the evidence they contain, we must acknowledge that much of this is undoubtedly perverted to some extent. As Sam Gill has aptly noted, "in collections of texts or in ethnographies ... the oral component is completely lost as is the original language ... the text is stripped of the tradition, separated from its cultural context. In this form it can only speak to our own sense of meaning and value." See Native American Religious Action, 51. I might also note that many of the stories to which reference will be made in the following discussion were collected after the close of the colonial period, that is, after 1866. In every case, however, the material cited was shared with those who recorded it by individuals who were living in the first generation after Confederation.

45. Recorded by Gorden, in "Wilderness Journeys in New Brunswick," 518.

46. Leland, The Mythology, Legends, and Folk-Lore of the Algonkins, 75-76.

47. Hardy, Sporting Adventures, 259-262.

48. Printed in The Nova Scotian, April 6, 1846; cited in Whitehead, The Old Man Told Us, 229.

49. Petition of Chief Pemmeenauweet, CO. 217/179, 406-408; cited in Upton, Micmacs and Colonists, 134, and Whitehead, The Old Man Told Us, 218.

50. PANB, Rex/Px, vol. 40, 167; quoted in Hamilton and Spray, Source Documents Relating to the New Brunswick Indian, 126.

51. See Perley's Report of 1841, 3; Upton, Micmacs and Colonists, 128-129; Patterson, The Canadian Indian, 117; Wien, Rebuilding the Economic Base of Indian Communities, 19.

52. Perley's Report of $1841,3$.

53. Halleck, "The Restigouche," 430-431, noted that the Mi'kmaq at Mission Point, New Brunswick, were doing limited agriculture, with a more substantial emphasis on hunting, fishing, and lumbering. Cf. Patterson, The Canadian Indian, 117.

54. Wien, Rebuilding the Economic Base of Indian Communities, 18-19; Upton, Micmacs and Colonists, 129.

55. See Leighton, "The Twilight of the Indian Porpoise Hunters," 411 . Leighton notes that "without further refinement [the oil] was suitable for machinery and leather." Cf. Wein, Rebuilding the Economic Base of Indian Communities, 19.

56. Thomas Costin to Edward Winslow, March 23, 1804; cited in Raymond, Winslow Papers, 514. Winslow, a direct descendant of the first governor of Plymouth by the same name, had been dispatched by the British government to supervise the demobilization of Loyalist troops in Nova Scotia after the revolutionary war. He was one of the founders of the colony of New Brunswick. Cf. Raymond, $x, 5$.

57. Battiste, in "Micmac Literacy and Cognitive Assimilation," 33, notes that Nova Scotia's Annual Reports of the Department of Indian Affairs between 1843 and 1873 "indicated Micmacs' growing interest in learning to read." In his 1841 report, for instance, Perley claimed that the Mi'kmaq at Burnt Church "appeared very desirous of having schools" (4).

58. The Mi'kmaq at Eskasoni, Nova Scotia, for example, made such a request in 1845. ILANS, appendix 16, 1845, 69-71, and appendix 18,1846,66; cited in Ralston, "Religion, Public Policy, and Education of Micmac Indians," 186.

59. West, A Journal of a Mission to the Indians, 245-246.

60. Upton, Micmacs and Colonists, 116.

61. Perley, Report of 1841, 4. 
62. ILANS, appendix 50, 1844, 123-125, cited in Upton, Micmacs and Colonists, 226.

63. Upton, Micmacs and Colonists, 119.

64. The Nova Scotian, May 7, 1840, cited in Upton, Micmacs and Colonists, 136. Cf. Whitehead's reference in The Old Man Told Us, 216, to Charles Churchill, Memorials of Missionary Life in Nova Scotia, 1845. 1870.

65. Rand, Legends of the Micmacs, 279. The story was related to Rand in May of

66. Gill has suggested that, for many native Americans, food "is never isolated as a necessary but otherwise meaningless aspect of life. Food is never seen as simply 'for the body.' Whether the way of life is hunting, fishing, gathering, or farming, it is inextricably bound with a religious view of the world. ... It is this religious foundation that makes the killing of a bear, the gathering of herbs and acorns, the corn planting activities more than simple necessities for feeding the body. This religious foundation makes such activities crucial to the ongoing creation of the world." See Native American Religions, 138. For a discussion of the respect accorded food in the late seventeenth-century Mi'kmaq communities, see Le Clerq, New Relations of Gaspesia, 225-227.

67. Cardinal has pointed to this fundamental divergence in attitude toward white education between European and native American cultures. He suggests that native Americans "recognize that education is one of the major tools that will help us strike off the shackles of poverty and, incidentally, the tyranny of government direction. But the white man apparently believes that education is a tool for the implementation of his design of assimilation" (The Unjust Society, 51). In regard to the attitude among whites such as Perley of believing that the Mi'kmaq wanted to become "civilized," I refer to Thornton's suggestion that during the process of colonization, "many natives have accepted the detail of European civilization, but not its motive force . . . and it is this attitude which gives Europeans the impression that the native is ready enough to mimic them." See Thornton, For the File on Empire, 340.

68. Costin to Winslow, March 23, 1804, cited in Raymond, Winslow Papers, 514.

69. West, 246.

70. See, for example, Hemdry to Fairbanks, February $25,1863, J L C N S$, appendix $16,1863,3-4$, cited in Upton, Micmacs and Colonists, 95.

71. James Dawson's letter to Joseph Howe, June 25, 1842, PANS, Indian mss. RG1, vol. 432, 136-137, cited in Ralston, "Religion, Public Policy, and Education of Micmac Indians," 185.

72. See "The King's Daughter and the Man-Servant," in Rand, Legends of the Micmacs, 440-442.

73. See "The Doctor," in Rand, Legends of the Micmacs, 424-427.

74. Leland, The Algonquin Legends of New England, 106.

75. On the basis of what his guide, Michael Tom, told him, Campbell Hardy described Gluskap as "a denizen of heaven, who came down to examine the wonders of the earth" (Sporting Adventures, 248).

76. See Leland and Prince, Kuloskap the Master, 116.

77. Elder, "The Aborigines of Nova Scotia," 13.

78. Hardy, Sporting Adventures, 248-249.

79. Leland and Prince, Kuloskap the Master, 164-165. Grim and St. John suggest that dreams have generally functioned as conduits between the physical and spiritual 
worlds within northeastern American native cultures. They are "a vehicle for contacting power and thus gaining guidance for political and military decisions. New songs, dances, and customs were often received by the dreamer and were used to energize and reorder cultural life; dreams channeled power as consolation and hope during times of crisis and often initiated contact between visionary power and the shamans" ("The Northeastern Woodlands," 119).

80. See Leland and Prince, Kuloskap the Master, 157, Elder, "The Aborigines of Nova Scotia," 14; and Leland, The Algonquin Legends of New England, 61.

81. Leland and Prince, Kuloskap the Master, 116.

82. Battiste, in "An Historical Investigation," has noted that in traditional $\mathrm{Mi}^{\prime} \mathrm{kmaq}$ epistemology, two interrelated worlds are acknowledged to exist: "beyond the immediate world of perception, memory, imagination, and feelings exists another world from which knowledge, power, or medicine is derived and which the traditional native peoples have been taught in their oral tradition will aid them in their survival. The process of knowing is thus derived first from the immediate world through personal and tribal experiences, and secondly from one's interaction with the spiritual world. . . Since both worlds have a common base, a time when they were both one, they interact with one another to provide harmony between land and the life it supports" (46-47). "The road to the spirit world was one of following tribal custom and ritual, of fasting, prayer, and suspending the physical world" (79).

83. See Speck, "Some Micmac Tales," 60.

84. Speck, "Some Micmac Tales," 60-61.

85. This duality of meanings has been shared by many of the New World's displaced peoples. In speaking of the African American community, for instance, Charles Long has noted that the religious project of that community has generally been one of figuring "out some way by which we accepted the sheer facticity of our situation ... but did not accept it as the definition of who we were." Jones and Hardy, "From Colonialism to Community," 583.

86. Wallis and Wallis, The Micmac Indians of Eastern Canada, 470. For a good discussion of the implications of naming or renaming human beings, see Boskin, Sambo, 18. Boskin's analysis focusses upon the renaming of African American slaves by colonial Americans.

87. Wallis and Wallis, The Micmac Indians of Eastern Canada, 333-334. This story was recorded sometime between the summers of 1911 and 1912. 


\section{CHAPTER FIVE}

\section{AT HOME IN COLONIAL ACADIA}

\section{$\mathrm{W}$}

ITHIN both British and $\mathrm{Mi}^{\prime} \mathrm{kmaq}$ communities, the need for a sense of rootedness and continuity of place fuelled religious imaginations, giving rise to religious symbols that confronted the necessities of place while accounting for particular experiences. The lives that revolved around these were encrusted with myths that articulated specific instances of the unity provided by the symbols. In this sense, the religious imagination of all Acadia's people struggled with the problem of identity and origins in a new world. Yet the problem was resolved in a critically divergent manner by each community so that, overwhelmingly, two distinct visions of human meaning emerged: one that sought reconciliation with historical reality, and one that endeavoured to reject it.

Those people whose vision rejected historical reality were, in the first instance, confronted with a fundamental problem. The colonial need to be rooted in Acadia was frustrated by the fact that a sense of continuity of place was an impossibility-they were not at home. In response to the problem, they recoiled from the place itself and assumed the task of re-creating Acadia in the image of Britain, a place with which they felt some sense of continuity. The land that they recreated became meaningful space and a standard of measurement by which all else was judged to be chaotic; and the humans they imagined themselves to be were possessed of an identity carried over from another place and time. Identity itself became self-generated as the colonials affirmed their capacity to create themselves, uninfluenced by 
historical experience. Civilization and human progress became the symbols that reconciled the reality of discontinuity with their sense of being British. The Acadia they had fixed upon was wild, and so, profane. The necessity that it become civilized-and sacred-space justified the retention of a sense of meaning founded in another space.

Yet the vision of a British Acadia and of colonial peoples who were purely British required that any experience of alterity be avoided, for such experience constituted the nucleus of a potentially transformative process into which they had little desire to enter. As Kenneth Burke once suggested, "it is in the areas of ambiguity that transformations take place; in fact, without such areas, transformation would be impossible. ${ }^{1}$ Within the orb of this colonial vision, aboriginal peoples were situated in space that was profane. Like the uncultivated land that was without meaning, the $\mathrm{Mi}^{\prime} \mathrm{kmaq}$ were regarded as lacking human significance, and so were ignored altogether or imagined to be material for further acts of transformation. Even the desire to "civilize" the $\mathrm{Mi}^{\prime} \mathrm{kmaq}$ in order that they think and act like white colonials, no matter how much it was motivated by a recognition of their suffering, constituted a denial of their basic humanity. "In order to be determined... by an external factor," said Merleau-Ponty, "it is necessary that I should be a thing." ${ }^{2}$

Mutuality, and hence the experience of alterity that accompanies it, were incompatible with a British identity in Acadia. The myths that ran through this meaning of being in the New World gave a primordial structure to the reality of dispossession. At times, these demonstrated that the Mi'kmaq were fundamentally barbaric peoples who had been induced to less rude conduct through the progress of English culture. At other times, they attributed the near-annihilation of the $\mathrm{Mi}^{\prime} \mathrm{kmaq}$ to their own incompatibility with human progress. And at other times still, they sought to justify the appropriation of $\mathrm{Mi}^{\prime} \mathrm{kmaq}$ land and their modes of subsistence on the basis of their ultimate inclusion in the natural progression of human beings from primitive to European culture.

The $\mathrm{Mi}^{\prime} \mathrm{kmaq}$ were relegated to the peripheries of colonial society, tethered by the manipulation of incoherent messages from the white community. Just as Shakespeare's Prospero orchestrated the lives of other characters through the "artful manipulation of anxiety," 3 British colonials curtailed Mi'kmaq access to arenas of British meaning through the use of contradiction. As a Mi'kmaq petition to the Nova Scotia government explained in 1840:

Some people say we are lazy, still we work. If you say we must go and hunt, we tell you again that to hunt is one thing and to find meat is another. They say catch fish, and we try. They say make 
baskets, we do but we cannot sell them. They say make farms, this is very good, but will you help us till we cut away the trees, and raise the crop? We cannot work without food. The potatoes and wheat we raised last year were killed by the poison wind. ... All your people say they wish to do us good, and they sometimes give, but give a beggar a dinner and he is a beggar still. We do not like to beg. As our game and fish are nearly gone and we cannot sell our articles, we have resolved to make farms, yet we cannot make farms without help. We will get our people to make farms, build houses and barns, raise grain, feed cattle and get knowledge. ... What more can we say ${ }^{4}$

Of course, there was little to be said about any ambiguity in the Acadian experience that could have truly touched the colonial British. Their relationship with the native community was entangled in disparity, and it was virtually unassailable.

The most obvious form assumed by this ambivalence on the part of whites was the proliferation of discourse on allowing the Mi'kmaq access to the benefits of civilization and the virtual absence of tangible efforts in this respect. To make sense of such contradiction might require that we return to the issue of meaningful or civilized space in the colonial vision of Acadia. Both the British person and the re-created place constituted a pattern of significance surrounded by the chaos of wilderness (of which the Mi'kmaq were part|. As noted previously, margins are perilous constructions and conceptions, since any alteration of their shape brings about a shift in the structure of the pattern they contain..$^{5}$ If, therefore, what is peripheral were to be permitted to enter into a pattern of meaning, the matrix itself would have to be redefined to account for the change. Turning to the British in Acadia, we must begin by noting that they were not British. Coming to Acadia, settling in Acadia, dispossessing Acadia's people, encountering quantities of land and resources previously unknown had all contributed to the formation of a colonial population that was peculiar to its time and place, and although on some level they were aware of this, on another more critical level they clung tenaciously to their purity of identity. It may well be, then, that aboriginal peoples remained suspended at the peripheries of colonial society in order to ensure that the society could stand fast as an identifiable pattern in which colonials might continue imagining their British identity. Perpetuating what they perceived to be a qualitative distinction between themselves and the aboriginal population constituted a means of re-enforcing and preserving their notion of purity.

The experience of Moses Perley would certainly support this suggestion. Regardless of his motives for advocating the amelioration of the socio-economic condition of the Mi'kmaq, by actively pursuing his 
intention he clearly overstepped the limits of what the colonial government of New Brunswick expected of him; his suggestions and proposals were rarely, if ever, considered in more than a cursory fashion before being thrown aside. In addition to this, his recognition by the native community situated him squarely on the margin dividing the two communities, and that was a defiant and threatening position to occupy. The administration he served had little alternative but to release him, for as Mary Douglas noted, "any structure of ideas is vulnerable at its margins. ${ }^{16}$

The strength of the British sense of purity of origins was so profound that, when pressed to find some mode of portraying the distinctiveness of the colonies to the European community, the colonials looked to the Mi'kmaq community. At London's Great Exhibition of 1851, for instance, Nova Scotia represented itself with a display constructed overwhelmingly around items manufactured by the native population: "a canoe, paddles, a dress, cradle, chairs, mats, cigar cases, fans, purses, hoods, moccasins, [and] baskets." New Brunswick's exhibit was similarly arranged around three men in state attire with a canoe. $^{7}$

The conception of Acadia as an extension of another place thus abrogated the ability of colonials to acknowledge the distinct character of themselves and of the world in which they dwelled. Yet their proclivity for defining themselves in terms of the other place raises another issue with somewhat stark implications. The colonial British did not regard their identity as derivative of their historical experience of crossing the Atlantic Ocean and settling in a different continent. Nor did they consider it to be related to the palpable form of Acadia itself, for that form was overwhelmingly subsumed by their imagination. And they vehemently denied the impact on their meaning of the new human relationships Acadia engendered. These colonials perceived their identity to be internally generated. Yet, as Charles Taylor has noted, a sense of identity that evolves in this manner is problematic:

I can define my identity only against the background of things that matter. But to bracket out history, nature, society, the demands of solidarity, everything but what I find in myself, would be to eliminate all candidates for what matters. Only if I exist in a world in which history, or the demands of nature, or the needs of my fellow human beings, or the duties of citizenship, or the call of God, or something else of this order matters crucially, can I define an identity for myself that is not trivial. ${ }^{8}$

Taylor's reflection is astute, but his notion of triviality may underestimate the consequences of self-generated identity. The British creation of themselves was inextricably entwined in their re-creation of the 
world; Acadia as a British society was regarded as sacred space. As Joseph Howe la man described by an early twentieth-century historian as "Nova Scotia Incarnate" $\mid \rho$ demonstrated in his description of a colonial farmer who had spent his day working the land, the British flag signified hallowed space:

He lifts his eye and sees his flag unfurl'd,

The hope-the guide - the glory of a world,

Surveys the fabric, splendid and sublime,

Whose arch, like Heaven's, extends from clime to clime. ${ }^{10}$

The colonials, whom Howe believed had been initially recognized as gods by the $\mathrm{Mi}^{\prime} \mathrm{kmaq}^{11}{ }^{11}$ were burdened with a sense of guilt over the dispossession of aboriginal peoples. ${ }^{12}$ Yet, they exonerated themselves by either affirming the intrinsic value of the processes of civilization and progress in which they were involved, or by seeking to re-create the Mi'kmaq. They claimed the capacity to absolve themselves of their own transgression.

The British could create themselves and other human beings; they could confer absolution upon themselves; and they could sacralize the world about them by creating it. But in striving to create a garden of Acadia they refused, it seems, to believe that there had been anything of meaning in that space before. ${ }^{13}$ They were "the children of light" ${ }^{\prime 14}$ of another time and place who had made sail across the Atlantic waters to plant for the first time in the "virgin soil"15 that was the wilderness of Acadia. All this, one might consider, comes flagrantly close to resembling the story of the great planter of Genesis:

And the earth was without form, and void; and darkness was upon the face of the deep. And the Spirit of God moved upon the face of the waters. And God said, Let there be light: and there was light. And God saw the light: that it was good: and God divided the light from the darkness. ${ }^{16}$

Were the colonial British "gods," as Howe intimated? God, as Northrop Frye has noted, is at root simply "a process fulfilling itself." 17 The British regarded themselves as the embodiment of the process of human progress in the New World--the mode by which "civilization" (the fulcrum of their own identityl "advanced." 18 Their identity was an idea that sought to realize itself in someone else's space. As the Mi'kmaq of the nineteenth century might well have affirmed, when one regards oneself as God, the rest of creation may find itself to be in a precarious position.

The human beings in Acadia who sought reconciliation with historical reality were, like their colonial contemporaries, confronted with a basic problem. The Mi'kmaq were rooted in Acadia, but their sense 
of continuity of place was rendered tenuous by the ingress of Europeans who failed to recognize their presence as meaningful. In response to the problem, they strenuously asserted their established relationships with place and with each other, in the hope of surviving the onslaught of European advancement and of persuading the British to enter into relationships that would engender a new form of community appropriate to the human composition of Acadia. Meaningful space was consequently space in which various forms of interrelationships were acknowledged and nurtured, and the source of relationships themselves was the land and community. These assumed symbolic significance as they negotiated the chasm that lay between the conception of being meaningful and rooted people, and the experiences of both disregard and dispossession. Their vision of Acadia revolved around the imperative for mutuality, and their myths variously drew on the symbols of land and community to affirm $\mathrm{Mi}^{\prime} \mathrm{kmaq}$ significance and rootedness. Yet, unlike those of the British, Mi'kmaq myths did not assert a meaning of the human that rested on the non-meaning of others. Rather, they conferred a primordial structure upon the New World, and this structure contained sufficient space for all human beings-aboriginal or European-who acknowledged and respected their interrelationships with one another.

Human meaning, for the native community, emerged from a context of relationships. Identity originated in the experience of alterity rather than from an internal ordering of consciousness, so that ambiguity and diversity pervaded both the field in which human meaning was generated and identity itself. The Mi'kmaq regarded themselves as Mi'kmaq who were also New World peoples. Being New World peoples was a necessity for survival insofar as colonial oppression could not be avoided, and the threat of dispossession, illness, or starvation required that native peoples continually acknowledge and contend with the British presence in Acadia. Yet acknowledgment was made in $\mathrm{Mi}^{\prime} \mathrm{kmaq}$ terms. Being $\mathrm{Mi}^{\prime} \mathrm{kmaq}$ signified a fundamental valuation of the mutual and reciprocal nature of human existence. This valuation stood in marked contrast to the nature of European colonial existence, and so contained both a critique of contemporary society and a vision of more authentic community in a colonial world. ${ }^{19}$

Historians have generally regarded the nineteenth-century Mi'kmaq as a "powerless" people. ${ }^{20}$ Upton, for instance, described $\mathrm{Mi}^{\prime} \mathrm{kmaq}$ strategy for dealing with the intrusion of Europeans in terms of "a determination to hold onto what shreds of the old life remained while steadfastly refusing to accept the new values. Only too frequently this response shaded off into a resignation so complete that white observers refer to it as a state of utter moral demoralization. ${ }^{21}$ 
"Power" in this context has focussed on the incapacity of the native community to resist the devastation caused by European incursion into Acadia. This definition disregards a different modality of power that emerged from a people who were able to acknowledge the diversity of meanings contained by the New World. The Mi'kmaq survived the oppression of the nineteenth century. And they carried with them a vision of Acadia that negated British notions of meaning, while remaining fully aware of the character of the society itself. A few years ago, Charles Long suggested that

passive power is still power. It is the power to be, to understand, to know even in the worst historical circumstances, and it may often reveal a clearer insight into significant meaning of the human venture than the power possessed by the oppressors. ${ }^{22}$

The Mi'kmaq possessed this power.

British colonials in Acadia spoke of a purity of origins and a world of meaning devoid of human ambiguity. This discourse afforded them the power to claim Acadia as their home. The Mi'kmaq accepted Acadia's ambiguous human composition as unavoidable, but they knew that the colonials' sense of identity existed only in their language about themselves-that it had no more substance than the paper on which they wrote their treaties and legislative acts:

[Christ] made a man then, took the earth and made a man. The earth was black, when he got the man to walk, he was dark. This man went hunting all the time. He gave him a bow and arrow, to shoot with. One time he saw this man was getting lonesome. He went and made another man. He got white clay, and this man was a white man. His hair was red. Man-made-first, God was speaking to him, saying, "That is your own, will be with you all the time." Second-man had a sack, with papers in it. He was named Hadam. ${ }^{23}$

The Mi'kmaq afforded the diversity of the New World a primordial structure that rendered it a reality. Within that diversity there existed two modes of being: one in terms of a relationship with place and one in terms of the printed word. In this sense, the $\mathrm{Mi}^{\prime} \mathrm{kmaq}$ may well have understood the British better than the British understood themselves. The colonials' sense of meaning did not derive of an authentic relationship with Acadia, but neither could it constitute the unity with Europe that they supposed. Their identity was consequently a product of language, not of place. In this sense, the myth of Hadam is curiously reminiscent of Caliban's injunction in the third act of The Tempest:

\section{remember}

First to possess his books; for without them He's but a sot [and] hath not 
One spirit to command: they all do hate him

As Rootedly as I. Burn but his books. ${ }^{24}$

British and Mi'kmaq experiences and understandings of colonial Acadia were divergent, to say the least. With this in mind, we might return to one of the historical issues raised in chapter one-that of the relationship between history and multiple meanings. Colonial Acadia was a reservoir of such multiplicity. Its shores presented themselves to the European imagination as a "new creation" 25 - as far as aboriginal peoples were concerned, Europeans might well have landed on the Stygian Shore. For whites, Acadia was a place of hope where, with sufficient and appropriate effort, anyone could achieve what was desired. For the Mi'kmaq, it was a place of terror where, regardless of effort, survival itself became a tenuous undertaking. Creation and destruction were bedfellows in colonial Acadia, and it was from their coalescence that a new society emerged. ${ }^{26}$

Subsequent meanings of the human enterprise were as ambiguous as was the new society. The British confronted the world with an eye for its "improvement," regarding as significant those sectors of the wilderness that they had refashioned. Their notion of meaningful space pivoted on a compulsion to re-create the world they inhabited, and their sense of identity rested in a capacity to imagine the self apart from historical or geographical reality. For the British, the actual situation of the human being in history relinquished its constitutive significance to the interests of future possibilities. ${ }^{27}$

The Mi'kmaq encountered the world not as brute matter upon which to impose meaning, but as an arena of transactions that required human adjustment. Identity emerged as a consequence of one's ability to recognize the creative power of human, historical, geographical, or cosmic contexts in which the human being was situated. For the $\mathrm{Mi}^{\prime} \mathrm{kmaq}$, the historical situation of the person constituted a matrix out of which notions of significance derived. ${ }^{28}$

Acadia was fundamentally a place of ambiguity. Within its sphere, those who sought to create also destroyed; those whose experience was one of profound hope were often oblivious to those who lived in terror. Notions of meaning were likewise ambivalent-in one instance, defying the reality of history; in another, conceding to it. Clearly the place was not possessed of the social or individual purity the British imagined. In.terms of both experience and identity, it was riddled with diversity. By insisting that they commanded a purity of identity, white colonials denied themselves the option of appreciating the true character of their world and of exploring the very new possibilities for human community it contained. Rather, in the interest of 
sustaining their sense of purity, they sought to remove ambiguity from their field of vision-an exercise that had a horrific effect on the other humans in Acadia. To imagine their identity as unaltered, whites were compelled to adopt modes of existence founded in violence and selfdeception. Their corner of the New World was a place of diversity but much of it was lost to them.

Although the diversity threatened the survival of the native community, the Mi'kmaq did not have the luxury of pretending it was not real. From the 1790 s onward, day-to-day existence required constant vigilance; options for continued survival were assessed and reassessed, and then pursued in concrete terms. Of these, one option that found continual expression was the necessity to induce the British to not only acknowledge the human constitution of Acadia, but to allow their actions and notions of meaning to reflect the historical reality of their world.

The multiplicity of meanings tells us principally that Acadian history is about ambiguity and human destruction beneath a dominant veneer of purity and human progress. Perhaps the most striking ambiguity has to do with the fact that colonial Acadia itself was born of a particular European motion in time and space that forced upon nonEuropeans the exigency of dealing with colonial peoples. In the wake of "discovery," these Europeans failed to come to terms with the human and historical dynamic of the world that they had inaugurated. Indeed, in Acadia, it was the $\mathrm{Mi}^{\prime} \mathrm{kmaq}$ who confronted this reality, variously calling their British contemporaries to do the same. In this case, Europeans discovered very little. It was the $\mathrm{Mi}^{\prime} \mathrm{kmaq}$ who discovered the New World.

\section{Notes}

1. Burke, A Grammar of Motives, xix.

2. Merleau-Ponty, The Phenomenology of Perception, 434-435. This reference to Merleau-Ponty's work appears in Alverson, Mind in the Heart of Darkness, 6.

3. Greenblatt, Shakespearean Negotiations, 143.

4. Written February 8, 1840, reprinted in The Acadian Recorder, February 24, 1849, cited in Whitehead, The Old Man Told Us, 241.

5. Michael Taussig, in Shamanism, Colonialism, and the Wild Man, writes: "Wildness also raises the spectre of the death of the symbolic function itself. It is the spirit of the unknown and the disorderly, loose in the forest and encircling the city and the sown land, disrupting the conventions upon which meaning and the shaping functions of images rest. Wildness challenges the unity of the symbol. . . Wildness pries open this unity and in its place creates slippage and a grinding articulation between signifier and signified" (219). 
6. Douglas, Purity and Danger, 121.

7. Official Descriptive and Illustrated Catalogue of the "Great Exhibition of the Work of Industry of all Nations, 1851," 969-970, cited in Upton, Micmacs and Colonists, 140. Upton reflected, "Faced with the need to represent themselves to the outside world, the colonists could find little that was original in their own society. . . To display something distinctive, emblematic in its way, they had to turn to the crafts of the native people."

8. Taylor, The Ethics of Authenticity, 40-41.

9. Grant, The Tribune of Nova Scotia, 1.

10. From "Acadia," quoted in Kline, Beyond the Land Itself, 38-39.

11. Howe wrote, in "Acadia," "When first the Micmac's eye discerned the sail / Expanding to the gentle southern gale, / . . As the bark drew nigh, / He thought some spirit of the deep blue sky / Had, for a time, forsook its peerless home / With the red Hunter o'er the wilds to roam; / Or that a God had left his coral cave, / To breathe the air and skim along the wave" (Poems and Essays, 15).

12. I would suggest that even the quantity of discourse that focusses on justifying this violence demonstrated a sense of transgression.

13. I first considered the whole complex of "planting for the first time" during a lecture given by Charles Long, in which he was discussing the synchronic language of origins in European America. The lecture was in the context of the course "World History of Religion," at Syracuse University, during the winter of 1991.

14. Burtis, New Brunswick as A Home for Emigrants, 37.

15. Gesner, New Brunswick, 4.

16. Genesis 1:1-4.

17. See Frye, "The Ideas of Northrop Frye," The Canadian Broadcasting Corporation transcript of "Ideas," February 19 and 26, and March 5, 1990, 21: "there is no such thing as 'God,' because God is not a thing. He's a process fulfilling itself. That's how he defines himself: I will be what I will be."

18. Gesner, New Brunswick, 4.

19. In considering this duality of meaning within colonized peoples, I am reminded of W. E. B. Du Bois's reflections on the nature of the self for African Americans: "One ever feels his twoness, - an American, a Negro; two souls, two thoughts, two unreconciled strivings; two warring ideals in one dark body, whose dogged strength alone keeps it from being torn asunder. ... The history of the American Negro is the history of this strife,-this longing to attain self-conscious manhood, to merge his double self into a better and truer self. In this merging he wishes neither of the older selves to be lost. He would not Africanize America, for America has too much to teach the world. He would not bleach his Negro soul in a flood of white Americanism, for he knows that Negro blood has a message for the world. He simply wishes to make it possible for a man to be both a Negro and an American, without being cursed and spit upon by his follows, without having the doors of Opportunity closed roughly in his face" (The Souls of Black Folk, 3).

20. Trigger, "The Historians' Indian," 37. This tendency to regard aboriginal peoples as powerless has been longstanding in Canadian historiography. Jacqueline Gresko has discussed this problem in "White 'Rites' and Indian 'Rites," 163. She points to such historians as J. M. S.Careless who have propagated the notion of native submissiveness. Cf. Careless, Canada: $A$ Story of Challenge, esp. 22.

21. Upton, Micmacs and Colonists, xii. 
22. Long, Significations, 195.

23. See Parsons, "Micmac Folklore," 88-89. Parsons has noted that the stories she collected for this article had been told by.May Ducet Newell, who died in 1895 (55).

24. Shakespeare, The Tempest, 3. 2.91-95, in The Works of William Shakespeare.

25. Gesner, New Brunswick, 1.

26. In respect to the experience of terror, Guy Carleton received a letter from a Loyalist officer at the close of the eighteenth century, in which the officer noted: "They [the Mi'kmaq] consider the English as having taken away from them their hunting and fishing grounds, which is their only means of support. They are not favourably disposed towards us, and have been only kept in order by terror." Extracts from "Remarks on the Province of New Brunswick" by Daniel Lyman (1792), PANB, PRO, CO. 188/4, vol 63, 39 , cited in Hamilton and Spray, Source Materials Relating to the New Brunswick Indian, 61.

27. Barre Toelken explores this European American sense of future orientation in "Folklore, World View, and Communication," 269: "Anglo-American tradition deals with time and space in terms which insist that they can be, and ought to be, ordered, measured and planned ... [there is a] belief that indeed time is a lineal reality the ends of which can be conceived of and discussed [and hence] our fascination with New Frontiers of any sort, new directions, future promises, and so on."

28. Toelken goes on from his discussion of "Anglo-Americans" to say, "the central interests of Indian life are largely served through mutual concerns, human interactions, and reciprocating responsibilities among men and between man and nature. The Indian sees himself as in nature, surrounded by it, not placed over it in position to impose a plan" ("Folklore, World View, and Communication," 273-274). 
This page intentionally left blank 


\section{CONCLUSION}

\section{Still Strangers}

$I$ BEGAN this inquiry by noting that one or another form of alienation appears to have been the experience of all Acadia's peoples. The bulk of this work has concerned itself with a search for the historical roots of alienation, but it may not have constituted a historical analysis in any familiar sense of the term, since it has consciously focussed upon human religiosity as that which gives meaning to history. History, like religion, is very much a product of the scholar's own historical context as well as of the scholar's purpose for writing. In that sense, this historical work is no different from those of George Heriot and John William Dawson. Heriot spoke of Indians in positive terms at a time when the loyalty of native peoples was desired as a bulwark against American aggression. Dawson regarded them as innately people of reason who were underdeveloped because of circumstance, at a time when assimilation of the aboriginal population appeared to support a general vision of a white Canada. I have likewise focussed upon native peoples as strong and independent agents at a time when aboriginal peoples across the nation have forced all but the most stubborn to recognize them as so.

This work is also similar to recent ethnohistorical research that intends to "free mainstream North American history from its legacy of a colonial ideology." ${ }^{\prime 1}$ Yet where it differs from any of these also rests on the point of purpose. This analysis is the product of a self-conscious 
desire to discover a mode by which our recently "freed" North American history can have a constructive impact on our lives as post-colonial peoples. I have attempted to demonstrate that a way to achieve this may be by recognizing, first, the mythic structures of our conceptions of ourselves in history and, subsequently, the religious power these maintain over us. The issue of native-white relations in the colonial period has thus been interpreted as a pervasively religious issue.

From this vantage point, white alienation has been interpreted as a matter of being estranged from the reality of the place in which they have found themselves, an inability to acknowledge the autonomous meaning of the land and its native population, apart from the creative designs of Europeans. As a consequence, whites have failed in some fundamental manner to come to terms with the impact of the place and its human composition upon their own identities, and so they have failed to recognize themselves as New World peoples. In the process of living out such a denial of reality, colonial and post-colonial Maritime whites have forced the alienation of aboriginal peoples variously from land and food, and from arenas of social valuation imposed upon the Acadian landscape. They have made "strangers" of human beings whose families have lived in the Maritimes for thousands of years, and who have sought throughout the post-Columbian period to live in community with all Acadia's people.

In confronting the problem of alienation, this book began with the question of why it mattered to European colonials that they regard the Mi'kmaq in Acadia as strangers. I would now suggest that it mattered principally because the British sense of identity required a sharp distinction between itself and others in order to be sustained. In this respect, I believe this discussion could well be replicated in respect to many other dated and placed events in the colonial period, although that would clearly involve many other projects of this sort. If I might be permitted to bracket further research for the moment, I would like to conclude by taking up the challenge for transformation initially set out in chapter one, that is, in knowing why it was that colonials alienated themselves from particular aspects of Acadia, are we afforded the possibility of confronting our world in a more authentic manner? Can an understanding of our history free us from its constraint?

The necessity for this freedom is vital if we are to seriously confront the implications of alienation contained within Rita Joe's description of her people as "still strangers." In the final analysis, there is an aching sense of continuity in her words. In an 1865 biography of Peter Paul, a Mi'kmaq man from Nova Scotia, the author recorded a nineteenth-century plea that reverberates with the words of Rita Joe. Paul 
said: "white man you got my country; keep 'em good, be kind to poor Indian-he have no country now-call'em stranger here." ${ }^{2}$ In 1865, Peter Paul and his contemporaries had been drawn into a colonial recreation of Acadia that had resulted in their sense of having no place in which to meaningfully dwell. Whites had come to regard only those lives that were lived within this new creation as significant, and access to that arena was restricted to the descendants of Europeans. In 1991, Rita Joe pointed to the same social dissonance. In some critical respect, all Atlantic Canadians remain imprisoned by their history.

The alienation of all Acadia's people-of the $\mathrm{Mi}^{\prime} \mathrm{kmaq}$ from white structures of valuation and of whites from ourselves as New World peoples-emerged in the first instance from a European colonial need for a sense of continuity of place. Continuity, of course, was problematic for a group of people settling in a new place. Most had arrived in Acadia with a sense of identity that had been somehow disfigured, as well as a cultural inability to account for experiential ambiguity. Their problem was essentially one of reconstructing an identity that affirmed a sense of continuity-of truly being "at home"-within an environment that was brazenly unfamiliar. The solution to this problem lay in their imagining a British identity and re-creating Acadia in the image of English society. As a result of these creative acts, the land and people who could not be contained by the idea of English culture remained outside "civilization," at times invisible, at times emblems variously of the achievements of human "progress" or of its unfortunate but unavoidable ascendancy over other cultures. Always, however, colonials clung to the symbols of civilization and progress to justify their presence in Acadia and their British identity. Confronted with the actuality of both their historical situation and a collective identity that had been substantially recast by that situation, these colonials burrowed more deeply into their imaginations, and they constructed boundaries between themselves and non-Europeans in order to protect the purity of the cultural pattern on which their sense of meaning rested. The Mi'kmaq as "other" than civilized pointed to the distinctiveness of the white population. Colonials could consequently affirm their British identity by ensuring that the $\mathrm{Mi}^{\prime} \mathrm{kmaq}$ remain strangers.

As a mode of dealing with the world, alienation was a product of the human religious imagination as it was exercised in another time. Yet the problem of identity in eighteenth- and nineteenth-century colonial Acadia was a problem that we do not share with our progenitors. For better or for worse (depending upon one's cultural point of view|, white Maritime Canadians now possess a measure of continuity in their place. Unquestionably, it is not a continuity with the depth of millenniums that first peoples command, but the fact remains that 
whites are here and will not likely leave: on this planet, at least, there are no more worlds to be discovered.

The novelty of the New World lies foremost in its ambiguity and diversity. When Europe moved into the Atlantic, it initiated a shift in world culture in which all the world's peoples were to touch one another in a previously unknown fashion. ${ }^{3}$ Something very new did indeed emerge from the context of colonial contact, but it had little relationship with the languages of cultural purity that enveloped colonial Europeans such as the Acadian British. It had very much more to do with the presence of canoes and quill boxes at London's Great Exhibition, with the conferral of the title of honorary chief upon a white man who had earlier been fined ten pounds for killing a native American, with white soldiers claiming bounties on the scalps of aboriginal peoples, and with aboriginal peoples scaling the channels of colonial bureaucracies. The New World had also to do with farming and logging and unlimited possibilities for social mobility, and with hunger and disease and fifty people sharing ten blankets. From its inception, this world was simultaneously about hope and despair, life and death, creation and destruction. Those who lived in the sphere of hope and creation saw little more than these, yet those who were forced to withstand the aspirations of colonial Europeans recognized the fundamental ambiguity of the New World-that discovery was an act of creation that wrought overwhelming destruction.

In this sense our reputation, as the heirs of colonizers, is sealed, and we are consequently stuck where we are. As Lévi-Strauss reflected near the end of Tristes Tropiques,

our adventures into the heart of the New World have a lesson to teach us: that the New World was not ours to destroy, and yet we destroyed it; and that no other will be vouchsafed to us. ${ }^{4}$

Given the fact that we have nowhere else to go, it would appear that the time is upon us to seriously come to terms with the world in which we live. This investigation has constituted a possible point of departure for this task. We must understand that our modes of valuing the other people with whom we share our world are not related to the reality of the people themselves, but to a human need as it was experienced two hundred years ago. We must also realize that despite the fact that the "other" people had the same need, they emerged with very different valuations. In striving to remain "at home" in Acadia, for instance, the Mi'kmaq imagined a New World in which human diversity could constitute the foundation for new relationships and communities. Within such relationships, all human beings might be afforded significance and, consequently, the freedom to live, and to live as 
autonomous agents. Christ and Gluskap were primordial colleagues who jousted with the Acadian landscape, and who gave an originary structure to the meeting of Europeans and native Americans that rendered the diversity of the New World a reality from which the aboriginal peoples could not turn away. The $\mathrm{Mi}^{\prime} \mathrm{kmaq}$ response to ambiguity was a profound effort to extend the boundaries of community and to call the British to do the same, so that Acadia might become a space in which all people could reside in mutuality.

The necessity for spatial continuity in their existence compelled the British to re-imagine and reconstruct the land and its human component in such a way that aboriginal peoples became alienated from even the most basic necessities of life. The Mi'kmaq, on the other hand, confronted the need for continuity by imagining a mode by which the same land might concede the presence and significance of all its people. This diversity of meanings points us to the primary ambiguity of creation and destruction that others like the $\mathrm{Mi}^{\prime} \mathrm{kmaq}$ have known and withstood for a long time, and knowing this affords us some option for transformation. Lévi-Strauss also suggested that, "In grasping these truths, we come face to face with ourselves." 5 Yet what is it that really confronts us, except our own "otherness" ${ }^{6}$ We can claim no identity founded in another place and time for we have become who we are because of our new location on the globe. We are other than we have too long imagined ourselves to be, for we are nothing other than New World peoples, with identities founded in the ambiguity that defines our world.

We are, then, faced with a choice: to continue to live within a mythology that reflects the instability of early colonial peoples, or to recognize another field of meaning that does justice to the tenor of our world. As the literary critic Gaile McGregor has warned, "to be oblivious to the duplicity of one's own myths is to be fooled by them, condemned, in a sense, to act them out over and over again. ${ }^{17}$ To turn away from our own otherness will condemn us to an alienated mode of being in which we will continue to shroud our identity from ourselves and continue to make strangers of the very people who can tell us most about the nature of our world and our significance. "The captor," wrote A. P. Thornton, "is held as firmly by the chain as the captive."

Situating ourselves within another arena of meaning is not so herculean a transformation as it might appear. As humans, we have the capacity to live in many worlds of thought and action:

we live in several worlds, each more true than the one within it, and each false in relation to that within which it is itself enveloped. ... Truth lies in the progressive expansion of meaning. . . History, politics, the social and political universe, the physical world, even the 
sky-all surround me in concentric circles, and I can only escape from those circles in thought if I concede to each of them some part of my being. ${ }^{9}$

We know that whites have situated all New World peoples in an essentially mythical world. If this world, this field of meaning, in which we now find ourselves to be is perceived as a vestige of some past reality that is not appropriate to our time and place, we have, on some level, already escaped from its constraint. It remains for us only to open our eyes and to truly discover a much more complex world that surrounds us-a world within which exist hitherto unimagined possibilities for human relationships. Many other peoples have been imagining these relationships for a very long time, for their experience of the New World has not afforded them the option of closing their eyes to diversity. They can tell us much about the larger "circle" of meaning in which we are situated, if we chose to enter it.

When Europe stumbled upon "that time so new and like to no other, ${ }^{\prime 10}$ it inaugurated a situation in which human origins and identity were to become issues particular to its own space, and problems to be borne by all its peoples. In that sense, we are all Columbus's descendants. We are now, as we have always been, confronted with a choice. We can live in a world of meaning that makes strangers of our partners in this enterprise we have called the New World (and strangers of ourselves, tool, or we can situate that world within a larger one in which non-Europeans have been living all along. By moving into this larger context, we would chose to see and hear other meanings of ourselves that have never pierced the smaller circle-meanings that contain an authenticity of identity we have yet to experience. I hope that in this time we might make the choice for authenticity.

If the Indians today

Are not fictitious,

Then know them ...11

\section{Notes}

1. Trigger, "The Historians' Indian," 337.

2. Quoted in Whitehead, The Old Man Told Us, 267.

3. Long made this point in his introduction to Baudet's Paradise on Earth, especially on page $x i$.

4. Lévi-Strauss, Tristes Tropiques, 392.

5. Lévi-Strauss, Tristes Tropiques, 392. 
6. I have borrowed this term from a lecture given by Long for his course "World History of Religion" (Syracuse University, winter 1991). Long said that in order to formulate a discourse in opposition to that of "conquest," we "must first come to terms with our own otherness."

7. Gaile McGregor, The Wacousta Syndrome, 53-54.

8. Thornton, For the File on Empire, 341.

9. Lévi-Strauss, Tristes Tropiques, 396.

10. The quote is attributed to Las Casas and is quoted in Todorov, The Conquest of America, 5.

11. Joe, Poems of Rita Joe, 2. 
This page intentionally left blank 


\section{BIBLIOGRAPHY}

AkINs, Thomas B. History of Halifax City. Halifax, 1895.

- Selections from the Public Documents of the Province of Nova Scotia. Halifax, 1869.

Albenese, Catherine L. America: Religions and Religion. Belmont, California: Wadsworth Publishing, 1981.

AlVERSON, Hoyt. Mind in the Heart of Darkness: Value and Self-Identity among the Tswana of Southern Africa. New Haven: Yale University Press, 1978.

AXTELL, James. The European and the Indian: Essays in the Ethnohistory of Colonial North America. New York: Oxford University Press, 1981.

- The Invasion Within: The Contest of Cultures in Colonial North America. New York: Oxford University Press, 1985.

BAILEY, Alfred Goldsworthy. The Conflict of European and Eastern Algonkian Cultures, 1504-1700: A Study in Canadian Civilization. 2nd ed. Toronto: University of Toronto Press, 1969. [First published in 1937.]

BAIRD, William Thomas. Seventy Years of New Brunswick Life: Autobiographical Sketches. St. John, New Brunswick, 1890.

Battiste, Marie Ann. "An Historical Investigation of the Social and Cultural Consequences of Micmac Literacy." Ed.D. thesis, Stanford University, 1984.

-. "Micmac Literacy and Cognitive Assimilation." In Indian Education in Canada, vol. 1 "The Legacy," edited by Jean Barman, Yvonne Hebert, and Don McCaskill. Vancouver: University of British Columbia Press, 1986.

BAUDET, Henri. Paradise on Earth: Some Thoughts on European Images of NonEuropean Man. Middleton, Connecticut: Wesleyan University Press, 1988.

BeLL, Ian A. Defoe's Fiction. Totowa, New Jersey: Barnes and Noble Books, 1985 . 
BigGar, H. P. The Voyages of Jacques Cartier. No. 11. Ottawa: Publications of the Public Archives of Canada, 1924.

Bitterman, Rusty. "Economic Statification and Agrarian Settlement: Middle River in the Early Nineteenth Century." In The Island: New Perspectives in Cape Breton History, 1713-1990, edited by Kenneth Donovan, 71-87. Fredericton, New Brunswick, and Sydney, Nova Scotia: Acadiensis and University College of Cape Breton Press, 1990.

Buss, J. M., ed. Canadian History in Documents, 1763-1966. Toronto: Ryerson Press, 1966.

Boskin, Joseph. Sambo: The Rise and Demise of an American Jester. New York: Oxford University Press, 1986.

Braudel, Fernand. Capitalism and Material Life, 1400-1800. Translated by Miriam Kochan. London: Weidenfield and Nicolson, 1967.

-. The Mediterranean and the Mediterranean World in the Age of Philip II, vol. 1. Translated by Sian Reynolds. New York: Harper and Row, 1972.

- On History. Translated by Sarah Matthews. Chicago: University of Chicago Press, 1980.

BREBNER, J. S. "Subsidized Intermarriage with the Indians." Canadian Historical Review, 6, 1 (1925): 33-36.

Bromley, Walter. An Account of the Aborigines of Nova Scotia Called the Micmac Indians. London, 1822.

Bumsted, J. M. Henry Alline, 1748-1784. Toronto: University of Toronto Press, 1971.

BURKE, Kenneth. A Grammar of Motives. Berkeley and Los Angeles: University of California Press, 1969.

BurTis, W. R. M. New Brunswick as A Home for Emigrants: With the Best Means of Promoting Immigration, and Developing the Resources of the Province. St. John, New Brunswick: Barnes and Co., 1860.

CAmpbell, D., and R. A. MCLean. Beyond the Atlantic Roar: A Study of the Nova Scotia Scots. Toronto: McClelland and Stewart, 1974.

CAMPBell, G. G. The History of Nova Scotia. Toronto and Halifax: Ryerson Press, 1948.

CANNY, Nicholas P. "The Ideology of English Colonization. " William and Mary Quarterly, 3rd ser., 30 (1973): 575-598.

CARDINAL, Harold. The Unjust Society: The Tragedy of Canada's Indians. Edmonton: M. G. Hurtig, 1969.

Careless, J. M. S. Canada: A Story of Challenge. Toronto: Macmillan, 1970.

CASSIRER, Ernst. An Essay on Man. 1944. Reprint. New York and London: Yale University Press, 1969.

-. The Philosophy of Symbolic Forms. Vol. 2, Mythical Thought. New Haven and London: Yale University Press, 1955. 
CHARLEVOIX, P. F. X. Histoire et description générale de la Nouvelle France avec le journal historique d'un voyage fait par ordre du roi dans l'Amérique septentrionale. 3 vols. Paris, 1744 .

Снгттіск, V. L. O. Thomas Chandler Haliburton ("Sam Slick"): A Study in Provincial Toryism. New York: AMS Press, 1966.

CHuTE, Jane Elizabeth. "Ceremony, Social Revitalization, and Change: Micmac Leadership in the Annual Festival of St. Anne." Papers of the Twenty-Third Algonquin Conference, edited by William Cowan, 45-62. Ottawa: Carleton University Press, 1992.

Cocswell, Fred. "Literary Activity in the Maritime Provinces, 1815-1880." In Literary History of Canada, edited by Carl F. Klinck, 102-124. Toronto: University of Toronto Press, 1965.

-. "The Maritime Provinces." In Literary History of Canada, edited by Carl F. Klinck, 71-82. Toronto: University of Toronto Press, 1965.

Condon, Ann Gorman. The Loyalist Dream for New Brunswick: The Envy of the American States. Fredericton, New Brunswick: New Ireland Press, 1984.

Crosby, Alfred W., Jr. The Columbian Exchange: Biological and Cultural Consequences of 1492. Westport, Connecticut: Greenwood Publishing Co., 1972.

Cumming, Peter A., and Neil H. Mickenberg, eds. Native Rights in Canada. Toronto: The Indian-Eskimo Association of Canada and General Publishing Co., 1972.

CUtHBertson, Brian. The First Bishop: A Biography of Charles Inglis. Halifax: Waegwoltic Press, 1987.

Davis, Stephen A. The Micmac. Tantallon, Nova Scotia: Four East Publications, 1991.

Dawson, John William. Fossil Men and Their Modern Representatives. London, 1880.

DenYs, Nicolas. The Description and Natural History of the Coasts of North America (Acadia), edited by William F. Ganong. Toronto: The Champlain Society, 1908.

Dickason, Olive P. "From One Nation in the Northeast to 'New Nation' in the Northwest: A Look at the Emergence of the Métis." American Indian Culture and Research Journal, 6, 2 (1982).

-. "Frontiers in Transition: Nova Scotia, 1713-1763, Compared to the NorthWest, 1869-1885." In 1885 and After: Native Society in Transition, edited by F. Laurie Barron and James B. Waldram, 23-38. Regina: University of Regina Press, 1986.

-. "Louisbourg and the Indians: A Study in Imperial Race Relations, 17131760." History and Archaeology 6 (1976).

Douglas, Mary. Natural Symbols: Explorations in Cosmology. New York: Vintage Books, 1970. 
-. Purity and Danger: An Analysis of Concepts of Pollution and Taboo. New York: Praeger Publishers, 1966.

Du Bois, W. E. Burghardt. The Souls of Black Folk. New York: Dodd, Mead and Co., 1961.

Eccles, W. J. The Canadian Frontier, 1534-1760. Toronto: Holt, Rinehart and Winston, 1969.

ELDER, William. "The Aborigines of Nova Scotia." North American Review, no. 230 (January 1871): 1-30.

EluADE, Mircea. Images and Symbols: Studies in Religious Symbolism. New York: Sheed and Ward, 1961.

-. Myth and Reality. New York and Evanston: Harper and Row, 1963.

-. Patterns in Comparative Religion. New York: New American Library, 1958.

- The Sacred and the Profane: The Nature of Religion. New York: Harper and Row, 1959.

FINGARD, Judith. The Anglican Design in Loyalist Nova Scotia 1783-1816. London: S.P.C.K., 1972.

-. "English Humanitarianism and the Colonial Mind: Walter Bromley in Nova Scotia, 1813-1825." Canadian Historical Review, 54, 2 (June 1973): 123151.

-. "The New England Company and the New Brunswick Indians, 1786-1826: A Comment on the Colonial Perversion of British Benevolence." Acadiensis, 1, 2 (Spring 1972): 29-42.

FisHER, Peter. The First History of New Brunswick. Saint John, New Brunswick: The New Brunswick Historical Society, 1921. [First published in 1825.]

FisHeR, Robin. Contact and Conflict: Indian-European Relations in British Columbia, 1774-1890. Vancouver: University of British Columbia Press, 1977.

Fogelson, Raymond D. "The Ethnohistory of Events and Nonevents." Ethnohistory, 36, 2 (Spring 1989): 133-147.

FRANCIS, Daniel, and Toby MORANTz. Partners in Furs: A History of the Fur Trade in Eastern James Bay, 1600-1870. Montreal and Kingston: McGill-Queen's University Press, 1983.

Friedman, Albert B. "The Usable Myth: The Legends of Modern Mythmakers." In American Folk Legend: A Symposium, edited by Wayland D. Hand, 37-45. Berkeley: University of California Press, 1971.

FRYE, Northrop. The Bush Garden: Essays on the Canadian Imagination. Toronto: Anansi Press, 1971.

-. Creation and Recreation. Toronto: University of Toronto Press, 1980.

- Divisions on a Ground: Essays on Canadian Culture. Toronto: Anansi, 1982.

-. "The Ideas of Northrop Frye." The Canadian Broadcasting Corporation transcript of "Ideas," February 19 and 26, and March 5, 1990. 
-. Spiritus Mundi: Essays on Literature, Myth and Society. Bloomington and London: Indiana University Press, 1976.

GARDNER, Howard. The Quest for Mind: Piaget, Lévi-Strauss, and the Structuralist Movement. New York: Alfred A. Knopf, 1973.

Garneau, François-Xavier. Histoire du Canada depuis sa découverte jusqu'à nos jours. 3 vols. Québec, 1845-1848.

GEERTZ, Clifford. The Interpretation of Cultures. New York: Basic Books, 1973.

- . "Religion as a Cultural System." In Anthropological Approaches to the Study of Religion, edited by Michael Banton, 1-46. London: Tavistock Publications, 1971.

GESNER, Abraham. New Brunswick, With Notes for Emigrants. London: Simmons and Ward, 1847.

Gill, Sam D. Native American Religions: An Introduction. Belmont, California: Wadsworth Publishing, 1982.

- Native American Religious Action: A Performance Approach to Religion Columbia, South Carolina: University of South Carolina Press, 1987.

- Native American Traditions: Sources and Interpretations. Belmont, California: Wadsworth Publishing, 1983.

GoRDEN, Arthur. "Wilderness Journeys in New Brunswick." In Vacation Tourists and Notes of Travel in 1862-3, edited by Francis Galton. London and Cambridge: Macmillan and Co., 1864.

Gould, G. P., and A. J. SempLe, eds. Our Land: The Maritimes. Fredericton, New Brunswick: Saint Annes Point Press, 1980.

Grant, William Lawson. The Tribune of Nova Scotia: A Chronicle of Joseph Howe. Toronto: Glasgow, Brook and Co., 1915.

GreENBLATT, Stephen. Shakespearean Negotiations: The Circulation of Social Energy in Renaissance England. Berkeley and Los Angeles: University of California Press, 1988.

Gresko, Jacqueline. "White 'Rites' and Indian 'Rites': Indian Education and Native Responses in the West, 1870-1910." In Western Canada: Past and Present, edited by Anthony W. Rasporich, 163-181. University of Calgary: McClelland and Stewart West, 1975.

GrIfFTTHS, Naomi E. S. The Acadians: Creation of a People. Toronto: McGrawHill Ryerson, 1973.

-. The Contexts of Acadian History, 1686-1784. Montreal and Kingston: McGill-Queen's University Press, 1992.

Grim, John A., and Donald P. St. John. "The Northeastern Woodlands." In Native American Religions, North America, edited by Lawrence E. Sullivan, 117-131. New York: Macmillan, 1987.

GroulX, Lionel-Adolphe. La naissance d'une race. Montreal, 1919.

Gunliemin, Jeanne. Urban Renegades: The Cultural Strategy of American Indians. New York and London: Columbia University Press, 1975. 
Hale, Horatio. The Iroquois Book of Rites. Philadelphia, 1883.

HALIBURTON, Thomas Chandler. An Historical and Statistical Account of Nova Scotia. Halifax: Joseph Howe, 1829.

- The Old Judge. Toronto: Clark, Irwin and Co., 1968. [First published in London by H. Colburne, 1849.]

HaLl, Edward T. The Silent Language. Garden City, New York: Doubleday and Company, 1959.

HalleCK, Charles. "The Restigouche." Harpers New Monthly Magazine, 36 (1867-1868): 424-443.

Hamilton, W. D. "Indian Lands in New Brunswick: The Case of the Little South West Reserve." Acadiensis 13, 2 (Spring 1984): 3-28.

Hamilton, W. D., and W. A. Spray. Source Materials Relating to the New Brunswick Indian. Fredericton: Hamray Books, 1976.

HAND, Wayland D., "The Index of American Folk Legends." In American Folk Legend: A Symposium, edited by Wayland D. Hand, 213-221. Berkeley: University of California Press, 1971.

HARDY, Campbell. Sporting Adventures in the New World: or Days and Nights of Moose-Hunting in the Pine Forests of Acadia. 2 vols. London: Hurst and Blackett, 1855.

Harvey, D. C., ed. The Diary of Simeon Perkins, 1780-1789. Toronto: Champlain Society, 1958.

-. Journeys to the Island of St. John or Prince Edward Island, 1775-1832. Toronto: Macmillan, 1955.

Herk, Welf H., ed. History and Myth: Arthur Lower and the Making of Canadian Nationalism. Vancouver: University of British Columbia Press, 1975.

Herbert, Mary E. Belinda Dalton: Or Scenes in the Life of a Halifax Belle. Halifax, 1859.

HERIOT, George. The History of Canada from Its First Discovery. London, 1804.

Hodgson, Marshall G. The Venture of Islam: Conscience and History in a World Civilization. Vol.1, The Classical Age of Islam. Chicago: University of Chicago Press, 1961.

Hollingsworth, S. The Present State of Nova Scotia With a Brief Account of Canada and the British Islands. Edinburgh and London, 1787.

HoRNsBY, Stephen. "Scottish Emigration and Settlement in Early Nineteenth Century Cape Breton." In The Island: New Perspectives in Cape Breton History, 1713-1990, edited by Kenneth Donovan, 49-69. Fredericton, New Brunswick, and Sydney, Nova Scotia: Acadiensis and University College of Cape Breton Press, 1990.

Howe, Joseph. Poems and Essays. Montreal: John Lovell, 1874.

Hutron, Elizabeth. "Indian Affairs in Nova Scotia, 1760-1834." Collections. Nova Scotia Historical Society, 1963. 
HUYGUE, Douglas S. Argimou: A Legend of the Micmac. Mount Allison University, 1977.

INNIs, Harold A. The Fur Trade in Canada: An Introduction to Canadian Economic History. Toronto: University of Toronto Press, 1970.

JANSON, Hugh. "The Esoteric-Exoteric Factor in Folklore." In The Study of Folklore, edited by Alan Dundas, 43-51. Englewood Cliffs, New Jersey: Prentice-Hall, 1965.

Jennings, Francis. Empire of Fortune: Crowns, Colonies, and Tribes in the Seven Years War in America. New York: W. W. Norton, 1988.

-. The Invasion of America: Indians, Colonialism, and the Cant of Conquest. New York: W. W. Norton, 1975.

JoE, Rita. Lnu and Indians We're Called. Charlottetown, Prince Edward Island: Ragweed Press, 1991.

-. Poems of Rita Joe. Halifax: Abenaki Press, 1978.

Johnston, Angus Anthony. A History of the Catholic Church in Eastern Nova Scotia. Vol. 2. Antigonish, Nova Scotia: Saint Francis Xavier University Press, 1960.

JONES, Carolyn M., and Julia Hardy. "From Colonialism to Community: Religion and Culture in Charles H. Long's Significations." Callalloo 2, 3 (Summer 1988).

KAPLAN, Sidney. "Historical Efforts to Encourage Indian-White Intermarriage in the United States and Canada." International Social Science Review, 65, 3: 126-132.

KLINE, Marcia B. Beyond the Land Itself: Views of Nature in Canada and the United States. Cambridge, Massachusetts: Harvard University Press, 1970.

LANE, Belden C. Landscapes of the Sacred: Geography and Narrative in American Spirituality. New York: Paulist Press, 1988.

LEACOCK, Eleanor B., and Nancy O. LAURIE, eds. North Amercian Indians in Historical Perspective. New York: Random House, 1971.

Le CleRQ, Chrétien. New Relations of Gaspesia, With the Customs and Religion of the Gaspesian Indians. Toronto: The Champlain Society, 1910.

LeightoN, Alexander H. "The Twilight of the Indian Porpoise Hunters." Natural History, 40 (1937): 410-416, 456.

LELAND, Charles Godfrey. The Algonquin Legends of New England, or Myths and Folklore of the Micmac, Passamaquoddy and Penobscot Tribes. Boston, 1884.

-. The Mythology, Legends, and Folk-Lore of the Algonkins. 1886.

Leland, Charles Godfrey, and John Dyneley Prince. Kuloskap the Master: And Other Algonkin Poems. New York and London: Funk and Wagnalls Co., 1902.

LeSCARBOT, Marc. Nova Francia: A Description of Acadia 1606. New York and London: Harper and Brothers, 1928. 
LeVINE, Donald N. The Flight from Ambiguity: Essays in Social and Cultural Theory. Chicago: University of Chicago Press, 1985.

LÉv-STrauss, Claude. "The Structural Study of Myth." Journal of American Folklore, 68, 270 (October-December 1955): 428-444.

-. Tristes Tropiques: An Anthropological Study of Primitive Societies in Brazil. Translated by John Russell. New York: Atheneum, 1970.

LOCHHEAD, Douglas, and Raymond Souster, eds. 100 Poems of Nineteenth Century Canada. Toronto: Macmillan, 1974.

LoNG, Charles H. "Primitive/Civilized: The Locus of a Problem." History of Religions, 20, 1 and 2 (1980): 43-61.

-. Significations: Signs, Symbols, and Images in the Interpretation of Religion. Philadelphia: Fortress Press, 1986.

-. "Silence and Signification: A Note on Religion and Modernity." In Myth and Symbol: Studies in Honor of Mircea Eliade, edited by Joseph M. Kitagawa and Charles H. Long, 141-150. Chicago: University of Chicago Press, 1969.

MACDONALD, Corinne. "The Sermons of Charles Inglis." Journal of the Canadian Church Historical Society, 33, 2 (October 1990): 24-38.

MACDONALD, M. A. Rebels and Royalists: The Lives and Material Culture of New Brunswick's Early English-speaking Settlers, 1758-1783. Fredericton, New Brunswick: New Ireland Press, 1990.

MacFarlane, R. O. "British Indian Policy in Nova Scotia to 1760." Canadian Historical Review, 19 (June 1938): 154-167.

MCGee, Harold Franklin. The Native Peoples of Atlantic Canada: A History of Indian-European Relations. Ottawa: Carleton University Press, 1984.

- "White Encroachment on Micmac Reserve Lands in Nova Scotia, 18301867." Man in the Northeast, 8 (1974): 57-64.

MCGrEGOR, Gaile. The Wacousta Syndrome: Explorations in the Canadian Landscape. Toronto: University of Toronto Press, 1985.

MaCKInNon, Neil. This Unfriendly Soil: The Loyalists' Experience in Nova Scotia, 1783-1791. Kingston and Montreal: McGill-Queen's University Press, 1986.

MCLENNAN, John Stewart. Louisbourg from Its Foundations to Its Fall, 17131758. London: Macmillan, 1918.

MCMullen, J. M. The History of Canada From its First Discovery to the Present Time. Brockville, 1855.

MacNutT, W. S. The Atlantic Provinces: The Emergence of Colonial Society, 1712-1857. Toronto: McClelland and Stewart, 1965.

- The Making of the Maritime Provinces. No. 4. The Canadian Historical Society, 1970.

Marllard, Pierre. An Account of the Customs and Manners of the Micmakis and Maricheets, 1758. 
Martin, Joel W. Sacred Revolt: The Muskogee's Struggle for a New World. Boston: Beacon Press, 1991.

Mauss, Marcel. The Gift: Forms and Functions of Exchange in Archaic Societies. New York: W. W. Norton and Company, 1967.

-. Sociology and Psychology. London: Routledge and Kegan Paul, 1979.

MeINIG, D. W. The Shaping of America: A Geographical Perspective on 500 Years of History. Vol.1, Atlantic America, 1492-1800. New Haven and London: Yale University Press, 1986.

Metraux, Alfred. Voodoo in Haiti. New York: Oxford University Press, 1959.

MILler, J. R. Skyscrapers Hide the Heavens: A History of Indian-White Relations in Canada. Toronto: University of Toronto Press, 1989.

Miller, Perry. "Jonathan Edwards and the Great Awakening." In Interpreting Colonial America: Selected Readings, edited by James Kirby Martin, 386-397. New York: Harper and Row, 1978.

Miller, Virginia P. "The Decline of the Nova Scotia Micmac Population, A.D. 1600-1850." Culture, 2, 3 (1982): 107-120.

Mrтснам, Allison. Three Remarkable Maritimers. Hantsport, Nova Scotia: Lancelot Press, 1985.

MorR, John S. The Church in the British Era: From the British Conquest to Confederation. Toronto: McGraw-Hill Ryerson, 1972.

Monkman, Leslie. A Native Heritage: Images of the Indian in English-Canadian Literature. Toronto: University of Toronto Press, 1981.

Monro, Alexander. New Brunswick with a Brief Outline of Nova Scotia and Prince Edward Island. Halifax: Richard Nugent, 1855.

MOORE, Dorothy Emma. "Multiculturalism: Ideology or Social Reality?" Ph.D. thesis, Boston University, 1980.

Morrison, Kenneth M. The Embattled Northeast: The Elusive Ideal of Alliance in Abenaki-Euramerican Relations. Berkeley: University of California Press, 1984.

MOSSNER, Ernest Campbell. The Forgotten Hume: Le Bon David. New York: AMS Press, 1967.

Muller, Max. Chips From a German Workshop. London, 1867.

Murdoch, Beamish. History of Nova Scotia or Acadie. 2 vols. Halifax, 1866.

NASH, Gary B. Red, White and Black: The Peoples of Early America. Englewood Cliffs, New Jersey: Prentice-Hall, 1974.

NAYLOR, R. T. Canada in the European Age, 1453-1919. Vancouver: New Star Books, 1987.

Nova Scotia Historical Society. Collections. Vol. 8. Halifax, 1892-1894.

O'GoRMAN, Edmundo. The Invention of America: An Inquiry into the Historical Nature of the New World. Bloomington, Indiana, 1961. 
Parkman, Francis. The lesuits in North America in the Seventeenth Century. Boston, 1867.

Parsons, Elsie Clews. "Micmac Folklore." The Journal of American Folk-Lore, 38 (1925): 55-133.

PatTerson, E. Palmer. The Canadian Indian: A History since 1500. Don Mills, Ontario: Collier-Macmillan, 1972.

PeArCE, Roy Harvey. Savagism and Civilization: A Study of the Indian and the American Mind. Baltimore: Johns Hopkins Press, 1953.

Perley, Moses. Camp of Owls: Sporting Sketches and Tales of Indians. Hantsport, Nova Scotia: Lancelot Press, 1990. [First published in 1839.]

-. Reports on Indian Settlements. Dated December 11, 1841.

PiCHON, Thomas (An Impartial Frenchman). Letters and Memoirs Relating to the Natural, Civil, and Commercial History of the Islands of Cape Breton and Saint John. London: J. Nourse, 1760.

POPESCU, Mircea. "Eliade and Folklore." In Myth and Symbols: Studies in Honor of Mircea Eliade, edited by Joseph M. Kitagawa and Charles H. Long, 8190. Chicago: University of Chicago Press, 1969.

QuINN, David Beers, ed. "The Voyages and Colonizing Enterprises of Sir Humphrey Gilbert." Publications, 2nd ser., 84. London: The Hakluyt Society, 1940.

Ralston, Helen. "Religion, Public Policy, and the Education of Micmac Indians of Nova Scotia, 1605-1872." Canadian Review of Sociology and Anthropology, 18, 4 (November 1981): 470-498.

RAND, Silas T. Legends of the Micmacs. London, 1894.

- . A Short History of Facts Relating to the History of the Micmac Tribe etc. . . Halifax, 1850.

RAwLYK, George A. "New Lights, Baptists, and Religious Awakenings in Nova Scotia, 1776-1843: A Preliminary Probe." Journal of the Canadian Church Historical Society, 25, 2 (October 1983): 43-73.

-. "The 1770s." In Colonists and Canadians, 1760-1867, edited by J. M. S. Careless. Toronto: Macmillan, 1971.

-. Wrapped Up in God: A Study of Several Canadian Revivals and Revivalists. Burlington, Ontario: Welch Publishing Co., 1988.

Rawlyx, George, ed. New Light Letters and Songs. Hantsport, Nova Scotia:Lancelot Press, 1983.

RAY, A. J. Indians in the Fur Trade: Their Role as Hunters, Trappers, and Middlemen in the Land Southwest of Hudson Bay, 1660-1870. Toronto: University of Toronto Press, 1974.

Ray, A. J., and D. B. Freeman. Give Us Good Measure: An Economic Analysis of Relations between the Indians and the Hudson Bay Company before 1763. Toronto: University of Toronto Press, 1978.

Raymond, William Odber, ed. Winslow Papers, A.D. 1776-1826. Boston: Gregg Press, 1972. 
RED, John G. Six Crucial Decades: Times of Change in the History of the Maritimes. Halifax: Nimbus Publishing, 1987.

ReLPH, Edward. Place and Placelessness. London: Pion Ltd., 1976.

Ricoeur, Paul. The Contribution of French Historiography to the Theory of History. Zaharoff Lectures. New York: Oxford University Press, 1980.

-. Political and Social Essays. Edited by David Stewart and Joseph Bien. Athens, Ohio: Ohio University Press, 1974.

SaUER, Carl O. Seventeenth Century North America. Berkeley: Turtle Island, 1980.

Scoby, Charles H. H., and John Webster GRANT. The Contribution of Methodism to Atlantic Canada. Montreal and Kingston: McGill-Queen's University Press, 1992.

SHAKESPEARE, William. The Works of William Shakespeare. London: George Harrap, nd.

SLotkin, Richard. Regeneration through Violence: The Mythology of the American Frontier, 1600-1860. Middletown, Connecticut: Wesleyan University Press, 1973.

SmrrH, Derek G., ed. Canadian Indians and the Law: Selected Documents, 1663-1972. Toronto: McClelland and Stewart, 1975.

SMTH, Jonathan Z. Imagining Religion: From Babylon to Jonestown. University of Chicago Press, 1982.

-. Map Is Not Territory: Studies in the History of Religions. Leiden: E. J. Brill, 1978.

SmrrH, Norman K. A Commentary to Kant's Critique of Pure Reason. Atlantic Highlands, New Jersey: Humanities Press, 1962.

Sмrrн, William. History of Canada, From Its First Discovery, to the Peace of 1763. Quebec, 1815.

Sparling, Mary Christine. "The British Vision in Nova Scotia 1749-1848: What Views the Artists Reflected and Reinforced." M.A. dissertation, Dalhousie University, 1978.

SpeCK, F. G. "Some Micmac Tales From Cape Breton Island." The Journal of American Folk-Lore, 28 (1915): 59-69.

STEWART, Gorden T. Documents Relating to the Great Awakening in Nova Scotia, 1760-1791. Toronto: The Champlain Society, 1982.

SteWART, Gorden, and George Rawlyk. A People Highly Favoured by God: The Nova Scotia Yankees and the American Revolution. Toronto: Macmillan, 1972.

StruTt, Joseph. The Sports and Pastimes of the People of England. New York: Augustus M. Kelly, 1903.

Sullrvan, Lawrence E. Icanchu's Drum: An Orientation to Meaning in South American Religions. New York: Macmillan, 1988. 
TAussig, Michael. Shamanism, Colonialism, and the Wild Man: A Study in Terror and Healing. Chicago: University of Chicago Press, 1987.

TAYLOR, Charles. The Ethics of Authenticity. Cambridge, Massachusetts: Harvard University Press, 1991.

TEMPERLEY, Howard. "Frontierism, Capital, and the American Loyalists in Canada." Journal of American Studies, 13, 1 (April 1979): 5-27.

ThORNTON, A. P. For the File on Empire: Essays and Reviews. London: Macmillan, 1968.

Thwartes, Reuben Gold, ed. The lesuit Relations and Allied Documents. Vols. 2 and 3. New York: Pageant Book Company, 1959.

Trtuey, E. Brian. A Narrow Vision: Duncan Campbell Scott and the Administration of Indian Affairs in Canada. Vancouver: University of British Columbia Press, 1986.

ToBias, J. L. "Canada's Subjugation of the Plains Cree, 1879-1885." Canadian Historical Review, 64 (1983): 519-548.

ToDorov, Tzvetan. The Conquest of America: The Question of the Other. New York: Harper Perennial, 1992.

TOELkEN, Barre. "Folklore, World View, and Communication." In Folklore: Performance and Communication, edited by Dan Ben-Amos and Kenneth S. Goldstein, 265-286. The Hague and Paris: Mouton, 1975.

TrigGer, Bruce. The Children of Aataentsic: A History of the Huron People to 1660. Montreal and Kingston: McGill-Queen's University Press, 1976.

-. "The Historians' Indian." In Out of the Background: Readings on Canadian Native History, edited by Robin Fisher and Kenneth Coates, 19-44. Toronto: Longman, 1988.

-. "The Historians' Indian: Native Americans in Canadian Historical Writing from Charlevoix to the Present." Canadian Historical Review, 67, 3, (September 1986): 315-342.

-. The Indians and the Heroic Age of New France. No. 30. Ottawa: The Canadian Historical Association Booklets, 1977.

-. Natives and Newcomers: Canada's "Heroic Age" Reconsidered. Montreal and Toronto: McGill-Queen's University Press, 1985.

TruDEL, Marcel. The Beginnings of New France: 1524-1663. Toronto: McClelland and Stewart, 1973.

Tuan, Yi-Fu. Man and Nature. Association of American Geographers, 1971.

-. "Sacred Space: Explorations of an Idea." In Dimensions of Human Geography, edited by Karl W. Butzer. Research Paper 186. Chicago: University of Chicago Department of Geography, 1978.

Upron, L. F. S. "Colonists and Micmacs." Journal of Canadian Studies (August 1975): 44-56.

-. "Indian Affairs in Colonial New Brunswick." Acadiensis (Spring 1974): 3-26. 
-. "Indian Policy in Colonial Nova Scotia." Acadiensis (1975).

-. "Indians and Islanders: The Micmacs of Colonial Prince Edward Island." Acadiensis (Autumn 1976): 21-42.

- Micmacs and Colonists: Indian-White Relations in the Maritimes 17131867. Vancouver: University of British Columbia Press, 1979.

Van Gennep, Arnold. The Rites of Passage. Chicago: University of Chicago Press, 1960.

VAN KIRK, Sylvia. Many Tender Ties: Women in Fur Trade Society in Western Canada, 1670-1870. Winnipeg: Watson and Dyer, 1980.

VaughaN, Alden T., and Virginia Mason VaUGHAN. Shakespeare's Caliban: A Cultural History. Cambridge: Cambridge University Press, 1991.

WACH, Joachim. Introduction to the History of Religions. Edited by Joseph M.Kitagawa and Gregory D. Alles. New York: Macmillan, 1988.

Wallerstein, Immanuel. The Modern World System: Capitalist Agriculture and the Origins of the European World Economy in the Sixteenth Century. New York: Academic Press, 1974.

Walus, Wilson D., and Ruth Sawtell WaLLIS. The Micmac Indians of Eastern Canada. Minneapolis: University of Minnesota Press, 1955.

WASHBURN, Wilcomb E. "The Meaning of Discovery in the Fifteenth and Sixteenth Centuries." The American Historical Review, 68, 1 (October 1962): 121.

WeIN, Fred. Rebuilding the Economic Base of Indian Communities: The Micmac in Nova Scotia. Montreal: The Institute for Research on Public Policy, 1986.

WEST, John. A Journal of a Mission to the Indians of the British Provinces, of New Brunswick, and Nova Scotia, and the Mohawks, on the Ouse, or Grand River, Upper Canada. London: Seeley, 1827.

WHITE, Hayden. "The Forms of Wildness: Archaeology of an Idea." In The Wild Man Within: An Image in Western Thought from the Renaissance to Romanticism, edited by Edward Dudley and Maximillian Novak. Pittsburgh: University of Pittsburgh Press, 1972.

WHITEHEAD, Ruth Holmes. The Old Man Told Us: Excerpts from Micmac History, 1500-1950. Halifax: Nimbus, 1991.

WiLson, Daniel. Prehistoric Man: Researches into the Origin of Civilization in the Old and the New World. London, 1862.

WINDSOR, Kenneth N. "Historical Writing in Canada to 1920." In Literary History of Canada, edited by Carl F. Klinck, 208-250. Toronto: University of Toronto Press, 1965.

WINks, Robin W. The Blacks in Canada: A History. Montreal and Kingston: McGill-Queen's University Press, 1971.

WITHINGTON, Robert. English Pageantry: An Historical Outline. Vol. 1. New York and London: Benjamin Blom, 1918. 
This page intentionally left blank 


\section{INDEX OF NAMES}

A

Akins, Thomas B., 76

Albenese, Catherine L., 15

Alline, Henry, 28, 56, 57

Amherst, General, 76

Axtell, James, 3

\section{B}

Bailey, Alfred Goldsworthy, 3

Belcher, Jonathan, 34

Biard, Pierre, 74

Black, William, 56, 57

Bliss, Henry, 30

Braudel, Fernand, 18

Bromley, Walter, 35, 43, 79

Burke, Kenneth, 98

Burtis, W. R. M., 33

C

Caliban, 103

Carleton, Guy, 62

Cassirer, Ernst, 12

Charlevoix, P. F. X., 2

Chernley, William, 37, 44, 63

Chipman, Ward, 30

Christ, 88, 89, 113

Clemen, Carl, 4

Cogswell, Fred, 30
Columbus, Cristopher, 19, 114

Cornwallis, Edward, 59, 61

Cowdell, Thomas Daniel, 39

D

Dawson, John William, 2, 109

Defoe, Daniel, 29

de Poutrincourt, Jean de Biencourt, 74

Descartes, René, 30

Douglas, Mary, 19, 100

$\mathbf{E}$

Eliade, Mircea, 4, 15

$\mathbf{F}$

Fairbanks, Samuel, 41

Febvre, Lucien, 13

Fisher, Robin, 3

Francis, Daniel, 3

Frazer, James, 4

Freeman, D. B., 3

Frye, Northrop, 18, 101

G

Garneau, François-Xavier, 2

Geertz, Clifford, 17

Gesner, Abraham, 28, 29, 35, 36, 37, $40,59,63$ 
Gluskap, $79,80,87,88,89,90,113$

Goldsmith, Oliver, 30, 40

Gubbins, Joseph, 54

H

Hadam, 103

Haliburton, Brenton, 30

Haliburton, Thomas Chandler, 32 , 59,63

Hall, Edward, T., 12

Hardy, Campbell, 37, 64, 80

Harris, Moses, 32

Head, William, 35

Heik, Welf $\mathrm{H} ., 12$

Herbert, Mary Eliza, 65

Heriot, George, 2, 109

Hodgson, Marshall G., 13

Howe, Joseph, 30, 32, 34, 39, 64, 83, 85,101

Huygue, Douglas S., $36,38,63,66$

I

Inglis, Charles, 54

Innis, Harold A., 2

J

Jennings, Francis, 3, 13

Jeremy, John, 83

Joe, John, 88

Joe, Rita, 9, 110, 111

John, Saint, the Evangelist, 19

Julien, Joe, 88

Julien, John, 35

K

Kline, Marcia B., 28

L

Lane, Belden C., 15

Lawrence, Charles, 34, 76

Leacock, Eleanor, 62

Le Bone, Oliver Thomas, 83

Leland, Charles Godfrey, 80, 87

Leonard, George, 30

Lescarbot, Marc, 74

Levine, Donald N., 29

Lévi-Strauss, Claude, 6, 112, 113
Locke, John, 29

Long, Charles H., 4, 11, 103

Lupin, John, 85

M

McGregor, Gaile, 113

McIlwraith, Thomas, 2

McMullen, J. M., 2

Martin, Joel W., 20, 21

Mascarene, Paul, 75

Mather, Cotton, 56

Mauss, Marcel, 74

Membertou, Henri, 74

Merleau-Ponty, 98

Miller, J.R., 3, 10

Molesworth, Edward, 38

Monkman, Leslie, 65

Monro, Alexander, 37, 39

Montgomery, James, 34

Morantz, Toby, 3

Muis, André (Adelah), 83, 85

Müller, Max, 3

O

O'Gorman, Edmundo, 19

P

Paul, Louis-Benjamin Peminuit, 65, $78,79,81$

Paul, Peter, 110

Pearce, Roy Harvey, 12

Peckham, George, 59

Peminuit, Chief /see Paul, Louis-

Benjamin Peminuit)

Perley, Moses, 37, 38, 39, 41, 42, 44,

$62,63,82,83,85,99$

Pettazzoni, Raffaele, 4

Philips, Richard, 61

Prince of Wales, 41, 44, 83

Q

Queen Victoria, 37, 65, 78, 81, 84

$\mathbf{R}$

Rand, Silas T., 40, 79, 84, 86

Rawlyk, George, 58

Ray, A. I., 3

Relph, Edward, 16 
S

Shakespeare, William, 98

Silmoodawa, 84

Slotkin, Richard, 57

Smith, Jonathan Z., 4, 14

Smith, William, 2

Speck, F. G., 88

Sprott, John, 38

Stewart, Gordon T., 58

Stewart, R. B., 34

Sullivan, Lawrence E., 4

$\mathbf{T}$

Taylor, Charles, 100

Thom, Michael, 80, 87

Thornton, A. P., 113

Tobias, J. L., 3
Trigger, Bruce, 2, 3

Tuan, Yi-Fu, 31, 66, 67

U

Upton, L. F. S., 102

V

van der Leeuw, Gerardus, 4

Van Kirk, Sylvia, 3

w

Wentworth, Lieutenant-Governor, 61

West, John, 32, 33, 36, 39, 85

Winslow, Edward, 82, 85

Winthrop, John, 57 
$\infty$

The paper used in this publication meets the minimum requirements of American National Standard for Information Sciences -

Permanence of Paper for Printed Library Materials, ANSI Z39.48-1992.

Printed in November 1995 by

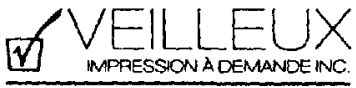

in Boucherville, Quebec 